\author{
UNIVERSIDADE DE SÃO PAULO \\ ESCOLA DE ENGENHARIA DE SÃO CARLOS \\ DEPARTAMENTO DE ENGENHARIA DE PRODUÇÃO
}

CAMILA FABRÍCIO POLTRONIERI

\title{
Avaliação do grau de maturidade dos Sistemas de Gestão Integrados (SGI)
}

São Carlos 



\title{
CAMILA FABRÍCIO POLTRONIERI
}

\section{Avaliação do grau de maturidade dos Sistemas de Gestão Integrados (SGI)}

\author{
Dissertação apresentada à Escola de Engenharia \\ de São Carlos, da Universidade de São Paulo, \\ como parte dos requisitos para a obtenção do \\ título de Mestre em Engenharia de Produção. \\ Área de Concentração: Processos e Gestão de \\ Operações.
}

Orientador: Prof. Dr. Mateus Cecílio Gerolamo

São Carlos 
AUTORIZO A REPRODUÇÃO TOTAL OU PARCIAL DESTE TRABALHO, POR QUALQUER MEIO CONVENCIONAL OU ELETRÔNICO, PARA FINS DE ESTUDO E PESQUISA, DESDE QUE CITADA A FONTE.

P779a Poltronieri, Camila Fabrício

Avaliação do grau de maturidade dos sistemas de Gestão Integrados (SGI) / Camila Fabrício Poltronieri; orientador Mateus Cecilio Gerolamo. São Carlos, 2014.

Dissertação (Mestrado) - Programa de Pós-Graduação em Engenharia de Produção e Área de Concentração em Processos e Gestão de Operações -- Escola de Engenharia de São Carlos da Universidade de São Paulo, 2014.

1. Sistemas de Gestão Integrados. 2. Modelo de Maturidade. 3. ISO 9001. 4. ISO 14001. 5. OHSAS 18001. I. Título. 


\section{FOLHA DE JULGAMENTO}

Candidata: Engenheira CAMILA FABRÍCIO POLTRONIERI.

Título da dissertaçăo: "Avaliaçāo do grau de maturidade dos sistemas de gestăo integrados (SGI)".

Data da defesa: $24 / 02 / 2014$

Comissão Julgadora:

Resultado:

Prof. Dr. Mateus Cecilio Gerolamo (Orientador)

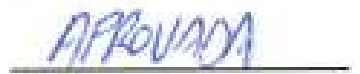

(Escola de Engenharia de São Carlos/EESC)

Prof, Dr. Rafael Henrique Palma Lima

APROVADA

(Universidade Federal do Triângulo Mineiro/UFTM)

APROVADA

Prof. Titular Luiz Cesar Ribeiro Carpinetti

(Escola de Engenharia de São Carlos/EESC)

Coordenador do Programa de Pós-Graduaçāo em Engenharia de Produção:

Prof. Titular Luiz Cesar Ribeiro Carpinetti

Presidente da Comissăo de Pós-Graduaçăo:

Prof. Titular Denis Vinicius Coury 

À minha mãe, que sempre me apoiou e incentivou. 



\section{Agradecimentos}

Em primeiro lugar agradeço à Deus por mais esta oportunidade de aprendizado e à minha mãe que sempre esteve ao meu lado, acreditando e torcendo por mim.

Não poderia deixar de agradecer muito ao professor Mateus pela orientação e atenção, bem como ao professor Carpinetti por toda contribuição e aprendizado. Foi muito importante poder contar com ambos em um momento tão difícil da minha vida, que acabou, de certa forma, impactando no meu mestrado. Se não fosse a ajuda de vocês, talvez não tivesse conseguido terminar. Obrigada por tudo! Agradeço também ao professor Rafael e a professora Ivete, por todas as sugestões dadas e pela forma criteriosa e detalhada com que analisaram meu trabalho.

Aos meus tios Nelma e Niles que sempre estiveram na torcida. À minha filhota de quatro patas Miuxa, que esteve ao meu lado e que mesmo sem saber não imagina o quanto me deu forças.

Aos amigos, já peço desculpas antecipadas por não ter conseguido citar o nome de todos, pois cada um, a seu modo, me ajudou muito nesse período. Obrigada Aline, André, Carol, Catarina, Fábio, Francisco, Lie, Lillian, Rosa, Yovana, aos amigos do SEOB, aos que mesmo distantes fisicamente estavam próximos em pensamento e aos demais amigos de laboratório e de departamento. Com certeza a caminhada é mais leve quando se pode contar com amizades verdadeiras. Infelizmente não vou conseguir colocar aqui o nome de todos, mas agradeço imensamente pela amizade de cada um de vocês que estiveram ao meu lado. À Gislaine e Daniela que com seus trabalhos me inspiraram no meu.

À todos os funcionários da secretaria e, em especial, à Sueli e Jéssyca, que sempre estiveram prontas a ajudar. Aos profissionais da indústria que contribuiram disponibilizando seu tempo e auxiliando na pesquisa.

À Coordenação de Aperfeiçoamento de Pessoal de Nível Superior (Capes), pelo apoio financeiro concedido. 



\section{RESUMO}

POLTRONIERI, C. F. Avaliação do grau de maturidade dos Sistemas de Gestão Integrados (SGI). 2014. 116 p. Dissertação (Mestrado) - Escola de Engenharia de São Carlos, Universidade de São Paulo, São Carlos, 2014.

Os sistemas de gestão estão sendo cada vez mais usados e é possível constatar isso através do aumento do número de empresas certificadas em normas tais como ISO 9001, ISO 14001 e OHSAS 18001. Tem-se observado que ao mesmo tempo em que cresce o número de certificações, tem sido cada vez mais comum as organizações adotarem mais de uma norma e como consequência há a necessidade e uma tendência de se integrá-las. A integração traz diversos benefícios como melhora na tomada de decisão, diminuição do risco de se ter atividades redundantes e contraditórias, bem como melhor utilização de recursos, entre outros benefícios. Devido aos benefícios que a integração oferece, é importante haver um instrumento que avalie o grau de maturidade dos Sistemas de Gestão Integrados (SGI), para que através dessa informação se possa promover melhorias para atingir uma integração maior. Através de uma revisão na literatura, notou-se que não há trabalhos que realizem a avaliação da maturidade da integração de sistemas de gestão tomando como ponto de apoio o conceito de modelos de maturidade. Ao perceber essa lacuna, resolveu-se elaborar um instrumento que avalie o grau de maturidade do SGI na empresas. No desenvolvimento deste trabalho, foi feita uma revisão exploratória seguida de uma revisão bibliográfica sistemática sobre SGI, também foi realizada uma pesquisa bibliográfica sobre modelo de maturidade. Estas revisões, contribuíram para atingir o propósito principal desta dissertação que é a elaboração de uma ferramenta para avaliar o grau de maturidade utilizando o conceito de Modelos de Maturidade e tendo como ponto de apoio dois modelos já consolidados como CMMI - Capability Maturity Model Integration e o modelo de maturidade apresentado na ISO 9004, além das normas ISO 9001, ISO 14001, OHSAS 18001 e NBR 16001. A ferramenta desenvolvida recebeu a avaliação de especialistas acadêmicos e profissionais da indústria, e ela conta com 21 questões divididas em 4 áreas, sendo elas Política; Planejamento; Implementação/Execução; e Verificação/Ação. Como resultado alcançado pela dissertação, pode-se destacar a apresentação de um panorama geral sobre as pesquisas em SGI, bem como a ferramenta de avaliação do grau de maturidade da integração dos sistemas de gestão. Conclui-se que tem aumentado ao longo dos anos trabalhos relacionados a SGI e que o estudo sobre isso é importante tanto do ponto de vista do mercado como acadêmico.

Palavras-chave: Sistemas de Gestão Integrados, Modelo de Maturidade, ISO 9001, ISO 14001, OHSAS 18001 



\begin{abstract}
POLTRONIERI, C. F. Assessment of the maturity degree of Integrated Management Systems (IMS). 2014. 116 p. Dissertation. School of Engeneering of São Carlos, University of São Paulo, São Carlos, 2014.
\end{abstract}

Management systems have been largely used, which can be verified by the increase in the number of ISO 9001, ISO 14001 and OHSAS 18001 certifications. As the number of individual certifications increase, more companies have faced the challenge of integrating multiple management systems. Integration is important because it improves decision-making, reduces redundant and conflicting activities and promotes a better utilization of resources. Due to the benefits that integration offers, it is important to have an instrument to assess the degree of maturity of Integrated Management Systems (IMS). With such information it would be possible to plan improvements and reach a greater integration. By carrying out a literature review, it was possible to note that there is not a tool to evaluate the maturity degree of IMS that employs the concept of maturity models. This work presents a tool that assesses the maturity degree of an IMS. An exploratory review as well as a systematic literature review about IMS were performed. In addition, a literature review on maturity models was also conducted. These reviews helped achieve the main purpose of this dissertation that it is the development of a tool to assess the maturity level using the concept of Maturity Models and having as support two well-established models: CMMI - Capability Maturity Model Integration and the maturity model presented in ISO 9004, alongside ISO 9001, ISO 14001, OHSAS 18001 and NBR 16001 standards. The tool has 21 questions divided into 4 areas: (i) policy, (ii) planning, (iii) implementation / execution and (iv) verification / action. Afterwards, the tool was assessed by academic experts and industry professionals. An overview of the research into IMS, as well as the maturity models oriented towards evaluating the integration of management systems can be pointed out as relevant results of this research. Another important finding is that the number of IMS-related studies has increased over the past years and such studies are considered important from both market and academic standpoints.

Keywords: Integrated Management System, Maturity Model, ISO 9001, ISO 14001, OHSAS 18001 



\title{
Lista de Abreviaturas e Siglas
}

\author{
ABNT Associação Brasileira de Normas Técnicas \\ BSI British Standards Institution \\ CMM Capability Maturity Model \\ CMMI Capability Maturity Model Integration \\ ISO International Organization for Standardization \\ NBR Norma Brasileira \\ OHSAS Occupational Health and Safety Assessment Series \\ PDCA Plan-Do-Check-Act \\ RBS Revisão Bibliográfica Sistemática \\ SGI Sistema de Gestão Integrado \\ SSO Segurança e Saúde Ocupacional
}





\section{Lista de Figuras}

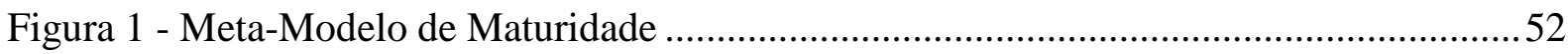

Figura 2 - Comparação entre os Níveis de Capacidade e os Níveis de Maturidade .................54

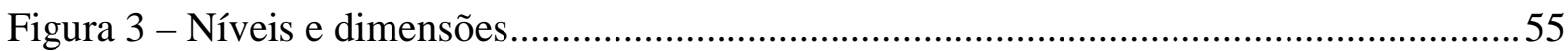

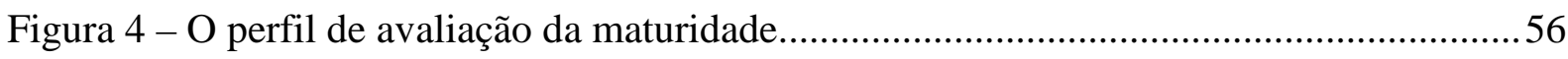

Figura 5 - Evolução da maturidade em gestão de projetos .................................................57

Figura 6 - Exemplo da avaliação do nível de maturidade em gestão da qualidade ..................58

Figura 7 - Exemplo de planilha para consolidação dos resultados ........................................59

Figura 8 - Exemplo do resultado da avaliação usando o método EcoM2 ................................59

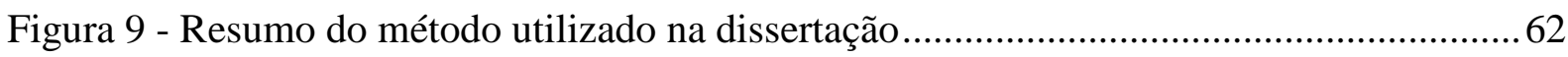

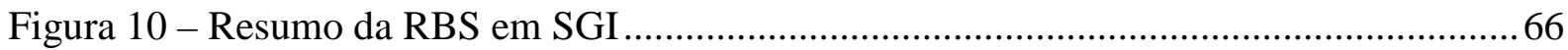

Figura 11 - Fases de desenvolvimento do modelo ..............................................................67

Figura 12 - Comparação entre os níveis de maturidade do CMMI e da Ferramenta de Avaliação do Grau de Maturidade em SGI ...................................................................... 74

Figura 13 - Versão inicial da Ferramenta de Avaliação do Grau de Maturidade em SGI ......75

Figura 14 - Ferramenta de Avaliação do Grau de Maturidade em SGI ..................................81

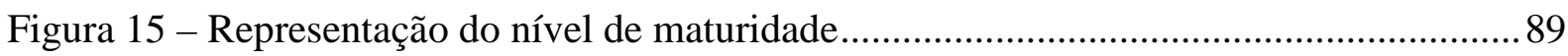

Figura 16 - Número de Questões da Ferramenta de Avaliação do Grau de Maturidade em SGI

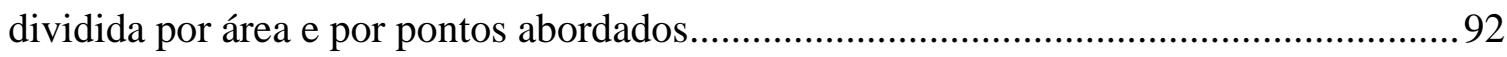

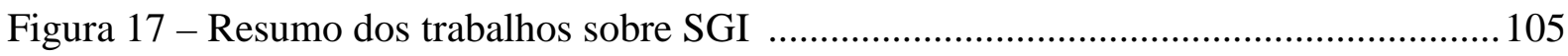





\section{Lista de Tabelas}

Tabela 1 - Relação dos 10 países que mais possuem certificados ativos ISO 9001 no ano de 2011 .

Tabela 2 - Relação dos 10 países que apresentaram maior crescimento no $\mathrm{n}^{\circ}$ de certificados ISO 9001 no ano de 2011

Tabela 3 - Relação dos 10 países que mais possuem certificados ativos ISO 14001 no ano de 2011

Tabela 4 - Relação dos 10 países que apresentaram maior crescimento de certificados no $\mathrm{n}^{\mathrm{o}}$ de ISO 14001 no ano de 2011.

Tabela 5 - Comparação entre os itens das normas

Tabela 6 - Principais autores que mais publicam sobre SGI por $\mathrm{n}^{\circ}$ de artigos publicados sobre SGI

Tabela 7 - Resultado do $1^{\circ}$ filtro em $\%$

Tabela 8 - Resultado do $2^{\circ}$ filtro em $\%$

Tabela 9 - Relação entre as questões da ferramenta e os itens das normas 69

Tabela 10 - Forma de pontuação da ferramenta. 89 



\section{Lista de Gráficos}

Gráfico 1 - Número de certificados ISO 9001 (Brasil) / Ano. .......................................................35

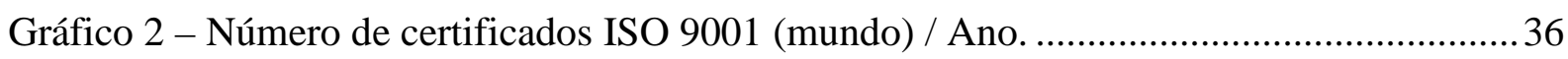

Gráfico 3 - Número de certificados ISO 14001 (Brasil) / Ano..................................................38

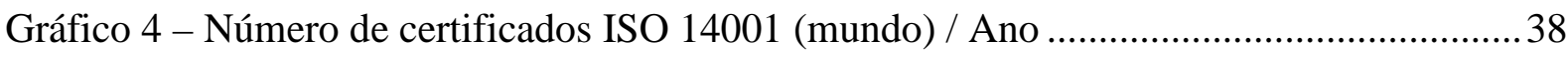

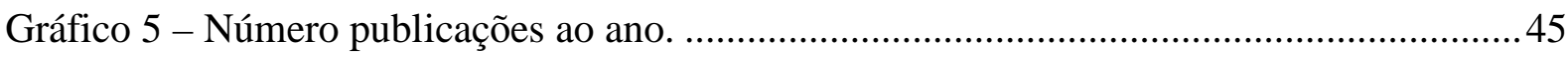

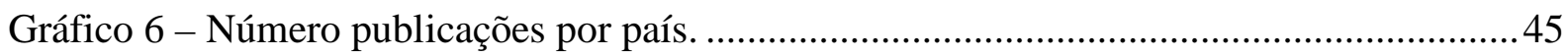

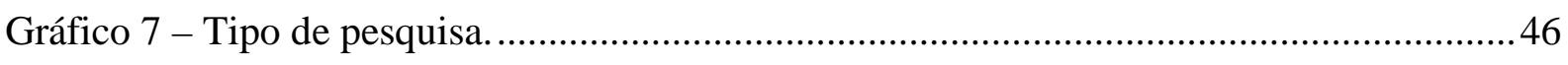

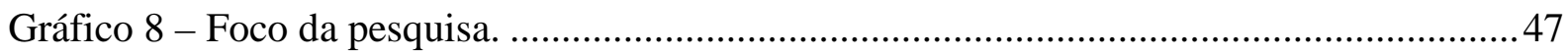

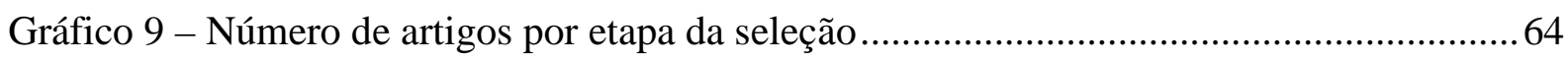

Gráfico 10 - Número de artigos por etapa da pesquisa.......................................................65 



\section{Sumário}

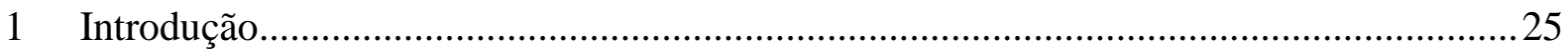

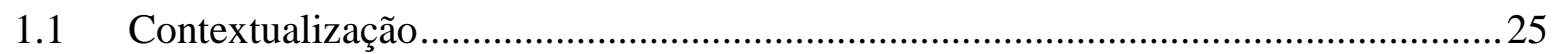

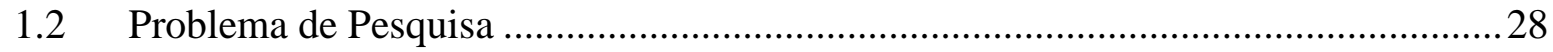

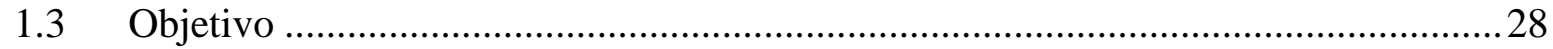

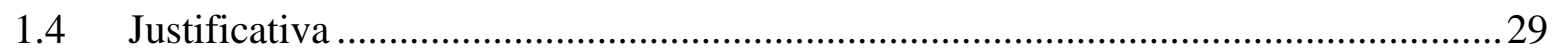

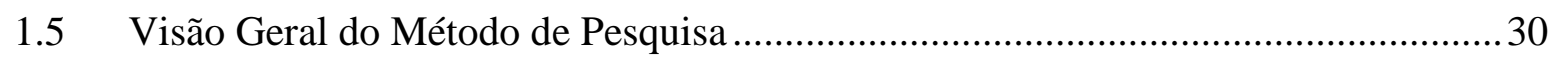

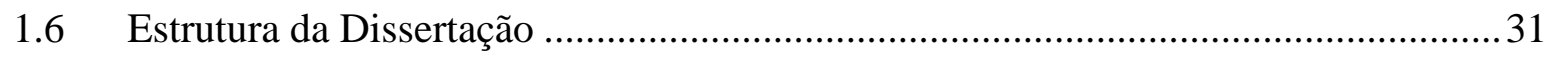

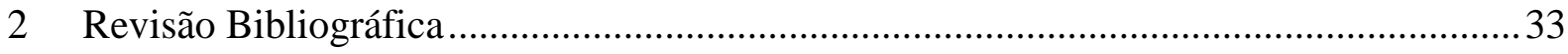

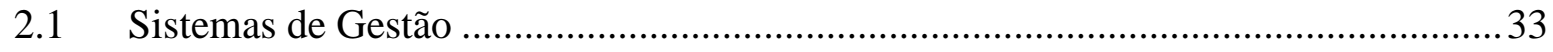

2.1.1 Sistema de Gestão da Qualidade - ISO 9001 ...................................................33

2.1.2 Sistema de Gestão Ambiental - ISO 14001 …...................................................

2.1.3 Sistema de Segurança e Saúde Ocupacional - OHSAS 18001 ...........................39

2.1.4 Sistema de Gestão de Responsabilidade Social - NBR 16001 ...........................39

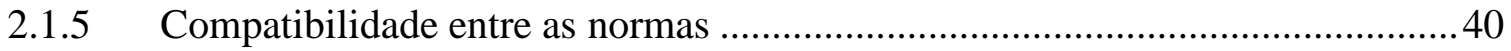

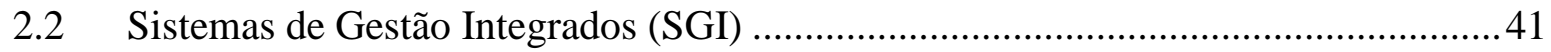

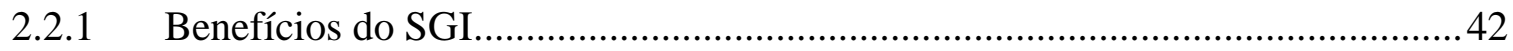

2.2.2 Barreiras para a Integração dos Sistemas de Gestão ........................................ 43

2.2.3 Recomendações para se Evitar Falhas na Integração dos Sistemas de Gestão ..43

2.2.4 Panorama Geral das Pesquisas Focadas em SGI .............................................. 44

2.2.5 Principais Trabalhos sobre Níveis de Integração ...............................................47

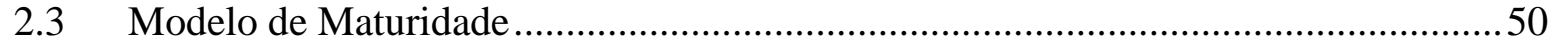

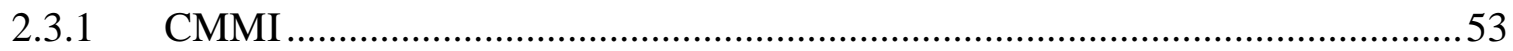

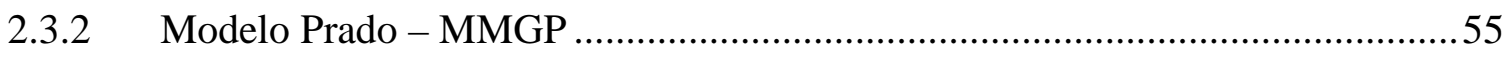

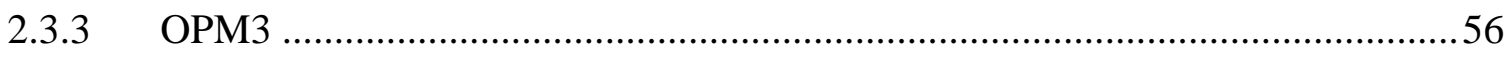

2.3.4 Modelo de Maturidade apresentado na ISO 9004:2010 ..................................57

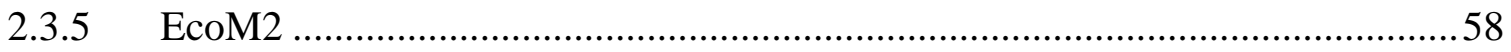

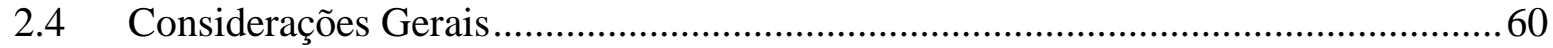

3 Método e passo-a-passo do desenvolvimento da pesquisa...........................................61

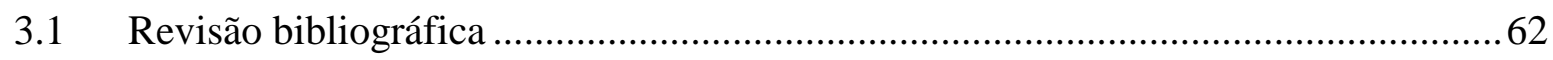

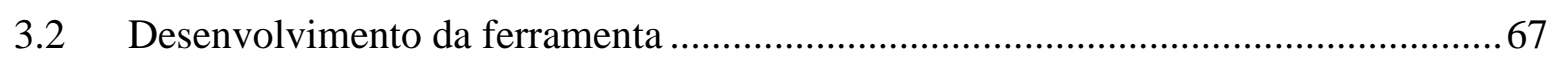

4 Proposta da Ferramenta de Avaliação do Grau de Maturidade em SGI ...........................73

4.1 Versão inicial da Ferramenta de Avaliação do Grau de Maturidade em SGI............73 
4.2 Ferramenta de Avaliação do Grau de Maturidade em SGI 81

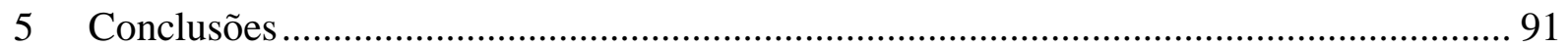

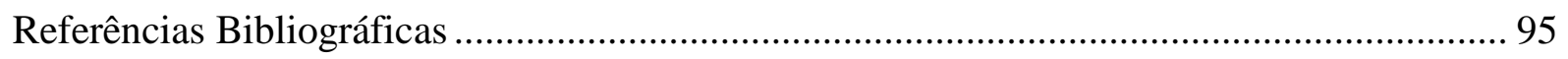

APÊNDICE A - Resumo dos trabalhos encontrados sobre SGI ....................................... 105

APÊNDICE B - Carta enviada às empresas onde os especialistas que avaliaram o instrumento

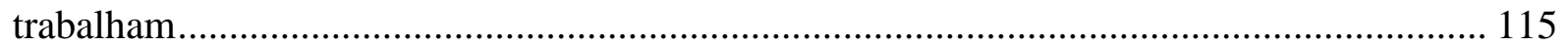

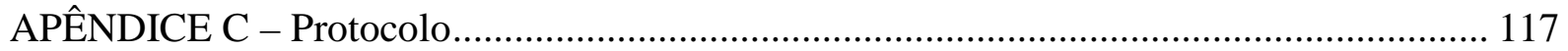




\section{Introdução}

\subsection{Contextualização}

Os padrões internacionais trazem diversos benefícios como a redução de custos, aumento da satisfação dos clientes, acesso a novos mercados, aumento do market share, além do fato de reduzir as chances de divergências provocadas pela existência de padrões regionais que dificultam a comercialização entre diferentes países (ISO, 2012a). A ISO 9001 - Sistema de Gestão da Qualidade é uma das normas de maior representatividade e sua primeira versão é de 1987. Muitas outras normas certificáveis e não certificáveis surgiram após esse período, como é o caso da ISO 14001 - Sistema de Gestão Ambiental lançada em 1996, a OHSAS 18001 Sistema de Gestão de Saúde e Segurança Ocupacional elaborada pela British Standards Institution em 1999, a NBR 16001 - Sistema de Gestão de Responsabilidade Social lançada em 2004 pela ABNT, entre outras normas de abrangência mundial ou regional. Cada uma dessas normas tem sofrido revisões ao longo dos anos.

O aumento da utilização de certificações como a ISO se deve ao seu caráter internacional e generalista. Inicialmente, sua utilização se deu no setor de manufatura, mas com o tempo foi ampliado para órgãos públicos, hospitais, transportes e muitos outros setores. Em resposta a requisitos específicos, a partir de 2000, a ISO começou a desenvolver novos padrões para atender a essas categorias, como foi o caso ISO/TS 16949 que é focada no setor automobilístico (BOIRAL, 2011). A origem da ISO/TS 16949 se deu a partir da norma QS 9000, a qual foi elaborada por grandes fabricantes de automóveis dos Estados Unidos e tinha uma aplicação mais restrita. Com o objetivo de ampliar a aplicação a nível mundial para todo o setor automobilístico, surgiu a ISO/TS 16949 (BORSARI, 2008).

De acordo com pesquisa divulgada pela ISO em Dezembro de 2012, referente ao ano de 2011, houve um aumento significativo de certificações dos sistemas de gestão referentes à segurança da informação, gestão ambiental, gestão de energia, assim como padrões específicos como para segurança alimentar, dispositivos médicos e automotivo. De 2010 para 2011, ao se levar em consideração o levantamento de 7 normas ISO, nota-se que houve um aumento de 17.607 certificações, o que representa $1 \%$ de acréscimo no número de certificados em relação ao ano anterior. Somente o sistema de gestão de segurança da informação teve um aumento de $12 \%$ com relação a 2010, assim como o sistema de gestão específico de segurança 
alimentar e do setor automobilístico que apresentaram um aumento de $8 \%$ cada um em comparação com 2010. Em 2011, apenas a ISO 9001 contava com 1.111 .698 certificações, sendo seguida pela ISO 14001 que apresentava 267.457 certificações, ou seja, é nítida a grande importância e representatividade que a ISO 9001 tem em termos de certificações frente as demais normas. A ISO tem a adesão de 164 organismos nacionais de padronização e conta com um portfólio de mais de 19.400 normas (ISO, 2012b).

Para Zeng, Shi e Lou (2007), a implantação de sistemas paralelos exige esforços duplicados para a organização, seja em termos de documentação, controle de formulários, procedimentos, etc.; além da dificuldade de assegurar o alinhamento desses diferentes sistemas de gestão com a estratégia da empresa. Se por um lado é possível encontrar problemas relacionados à utilização das normas em separado, de outro se nota um aumento no número de normas e de organizações que as adotaram. Portanto, torna-se importante pesquisar a integração das normas.

As normas tem se tornado mais compatíveis ao longo do tempo e diferentes países estão desenvolvendo seu próprio guia para orientar a integração delas, sendo que entre esses países estão Nova Zelândia, Austrália, França, Dinamarca, Espanha e Holanda (JØRGENSEN; REMMEN; MELLADO, 2006). Além dessas iniciativas promovidas por parte dos próprios países, em 2008 a ISO publicou o livro "The integrated use of management system standards", que fornece conselhos sobre como integrar sistemas de gestão normatizados, sendo que esse livro contou com o apoio de membros da ISO provenientes de organizações empresariais de diferentes países e setores, além de organismos de normatização e universidades (ISO, 2008).

De acordo com Heras-Saizarbitoria e Boiral (2012), a literatura sobre sistemas de gestão normatizados tem crescido nos últimos anos, porém, há um déficit devido à forma mal estruturada que essas pesquisas tem sido desenvolvidas. Um exemplo disso é que os estudos existentes sobre a motivação de se adotar sistemas de gestão focam nas respostas dos gerentes seniores, deixando de abordar a opinião dos demais gerentes e funcionários, bem como dos stakeholders que estão fora da empresa como fornecedores e consultores. Algumas das áreas de pesquisa que possuem lacunas segundo esses autores são as relacionadas à integração dos padrões, aos diferentes níveis de adoção, ao processo de auditoria, entre outros.

Assim como se tem popularizado a utilização de normas, nota-se um aumento na necessidade de se avaliar a maturidade em diversas áreas. Para Fraser, Moultrie e Gregory (2002), maturidade está atrelada à idéia de amadurecimento, transmitindo a noção de transição de um estágio inicial para outro avançado, podendo ser necessário passar por vários 
estágios intermediários até se atingir a maturidade efetiva. Maturidade significa que o processo é bem compreendido, documentado, aplicado constantemente na organização, além de monitorado e melhorado com regularidade. Os comportamentos maduros não aparecem aleatoriamente, mas devem ser desenvolvidos ao longo do tempo. Segundo Bruin et al. (2005), os modelos de maturidade contribuem para a avaliação da maturidade de uma área específica tomando como base um conjunto de critérios. Para Helgesson, Höst e Weyns (2012), a formulação de modelos de maturidade é vista como uma forma útil de comunicar as melhores práticas, pois consolida o conhecimento de um modo que auxilia nas iniciativas de melhorias.

A abordagem de maturidade tem sua origem em 1979 na gestão da qualidade com o trabalho de Crosby que propos o Aferidor de Maturidade da Gerência da Qualidade. Um dos mais conhecidos modelos desenvolvidos a partir do trabalho de Crosby foi o CMM (Capability Maturity Model - Modelo de Maturidade e de Capacidade), o qual consiste em um modelo de maturidade voltado para a área de software. Com base no conceito usado no CMM, vários outros modelos foram derivados (FRASER; MOULTRIE; GREGORY, 2002). Há modelos de maturidade para várias áreas entre elas: gestão da qualidade, desenvolvimento de software, desenvolvimento de produtos, inovação, entre outros. Inclusive, a norma ISO 9004 (ASSOCIAÇÃO BRASILEIRA DE NORMAS TÉCNICAS, 2010) apresenta um modelo de maturidade, porém o mesmo é voltado para avaliação dos sistemas de gestão da qualidade e não com foco na integração dos diferentes sistemas de gestão.

Segundo Wendler (2012), os modelos de maturidade oferecem às organizações um modo de medir a qualidade dos seus processos que ao mesmo tempo é simples e efetivo. Em seu artigo, o autor realizou uma revisão sistemática sobre modelos de maturidade e pode constatar que apesar de a aplicação de modelos de maturidade ser ampla, há uma grande concentração de trabalhos relacionados à área de desenvolvimento de software e engenharia de software. Somente entre os anos de 2009 à 2010 foram publicados 62 artigos sobre modelos de maturidade, sendo que 34 deles apresentavam a concepção de um novo modelo. Quanto ao método de pesquisa, nota-se que a maior parte das pesquisas possui foco no desenvolvimento conceitual, seguido por pesquisas empíricas tais como survey, estudo de caso e entrevistas. Outra descoberta dessa pesquisa é que a temática tem ganhado importância ao longo dos últimos anos e este fato pode ser constatado pelo número crescente de publicações, pois de 2003 até 2009 o número saltou de 15 para 34 artigos ao ano. 
A importância dos modelos de maturidade está no fato de auxiliarem na melhoria do desempenho organizacional, ajudando a identificar os pontos fracos $\mathrm{e}$ fortes (KHOSHGOFTAR; OSMAN, 2009).

\subsection{Problema de Pesquisa}

Ao mesmo tempo em que cresce a variedade de normas, aumenta o número de organizações que fazem uso delas e que muitas vezes implantam mais de uma norma. Através de estudos já realizados, nota-se que a integração entre essas diferentes normas se faz importante. Porém, tão importante quanto se analisar a questão da integração é avaliar o quão integrado estão as normas.

A Revisão Bibliográfica Sistemática (RBS) realizada neste trabalho sobre SGI ajudou a levantar os principais estudos e verificar as lacunas relacionadas a temática de sistemas de gestão. Um dos pontos que faltam estudos é justamente o que aborda a questão da maturidade em SGI. Portanto, o problema de pesquisa é conseguir avaliar a maturidade da integração de sistemas de gestão.

A principal pergunta de pesquisa é:

Como avaliar o grau de maturidade de um Sistema de Gestão Integrado?

\subsection{Objetivo}

O objetivo principal deste trabalho é estabelecer uma ferramenta para avaliar a maturidade da integração de sistemas de gestão.

Como objetivos secundários podem-se destacar:

- realização de uma RBS em relação à integração de sistemas de gestão

- levantamento das principais áreas de pesquisas em SGI, bem como onde as mesmas estão sendo desenvolvidas e sua evolução ao longo dos anos

- levantamento dos principais modelos de maturidade existentes 


\subsection{Justificativa}

Segundo López-Fresno (2010), trabalhar as normas de forma integrada traz diversos benefícios quantificáveis e não quantificáveis tais como a melhora na tomada de decisão, aperfeiçoamento da comunicação, utilização eficiente de recursos e aumento da motivação das pessoas. Jørgensen, Remmen e Mellado (2006) acrescentam que se a integração for vista como algo estratégico, promoverá melhores vantagens competitivas, bem como contribuirá para o desenvolvimento sustentável.

Se levado em consideração o tripé da sustentabilidade (social, ambiental e econômico), ao trabalhar com a ISO 9001, ISO 14001, NBR 16001 e OHSAS 18001, haverá uma contribuição direta para o desenvolvimento sustentável. Outros autores como Rocha, Searcy e Karapetrovic (2007), Jørgensen (2008) e Mežinska, Lapiṇa e Mazais (2013) também abordam a contribuição da integração dos sistemas de gestão para o desenvolvimento sustentável. A Associação Brasileira de Normas Técnicas (ABNT) lançou recentemente uma coletânea de normas técnicas intituladas "Gestão para Suporte à Sustentabilidade: 2012", a qual inclui um total de 13 normas entre elas: ABNT NBR ISO 14001:2004 - Sistema de Gestão Ambiental, ABNT NBR ISO 9001:2008 - Sistema de Gestão da Qualidade, ABNT NBR 16001:2012 Sistema de Gestão de Responsabilidade Social, ABNT NBR 18801:2010 - Sistema de Gestão de Segurança e Saúde no Trabalho e ABNT NBR ISO 26000:2010 - Diretrizes sobre Responsabilidade Social.

Com relação à maturidade, a sua representação através de número de estágios acumulativos, facilita a visualização de onde a empresa está e o quanto falta para ela atingir as melhores práticas, sendo que os estágios mais baixos servem de suporte para atingir os requisitos dos estágios mais altos (MAIER; MOULTRIE; CLARKSON, 2012). No entanto, apesar da grande utilidade, nota-se através da RBS que não há nenhum modelo de maturidade voltado para avaliar a integração de sistemas de gestão. Parte do que se encontrou na revisão são trabalhos que abordam as dificuldades e benefícios da integração, bem como níveis de integração. No entanto, no caso do nível de integração, os trabalhos encontrados se restringem a avaliar se os sistemas se encontram parcialmente/completamente integrados ou não, sendo que alguns dos principais estudos com essa temática são os de Jørgensen, Remmen e Mellado (2006), Salomone (2008), Bernardo, Casadesus, Karapetrovic e Heras (2009), Asif, Fisscher, Bruijn e Pagell (2010), Bernardo, Casadesus, Karapetrovic e Heras (2012), Simon, Karapetrovic e Casadesús (2012b) e Mežinska, Lapiṇa e Mazais (2013). Inclusive, esse último é o que mais se aproxima da proposta dessa dissertação, pois apresenta a elaboração de um 
instrumento que avalia a integração dos sistemas de gestão, no entanto, utiliza três gradações para avaliação e a forma como foi dividido o instrumento é diferente, não sendo levada em consideração a estrutura das normas para a divisão dos tópicos. Vale a pena destacar ainda que o trabalho de Mežinska, Lapiņa e Mazais não cita o conceito de modelo de maturidade, o que leva a acreditar que sua fonte de inspiração tenha sido os trabalhos desenvolvidos anterioremente por outros autores sobre níveis de integração embora a estrutura adotada remeta ao conceito de modelos de maturidade.

Frente à importância crescente da temática SGI, propõem-se com essa pesquisa elaborar uma ferramenta de avaliação do grau de maturidade da integração dos sistemas de gestão tomando como base modelos de maturidade conhecidos na literatura tais como o CMMI Capability Maturity Model Integration e o modelo de maturidade proposta na ISO 9004 Gestão para o Sucesso Sustentado de uma Organização: Uma Abordagem da Gestão da Qualidade. A contribuição da pesquisa está no fato de auxiliar as organizações a saberem em que nível de maturidade se encontra, pois através dessa informação elas poderão se planejar e avaliar melhor que direção seguir.

\subsection{Visão Geral do Método de Pesquisa}

Para o desenvolvimento desta pesquisa, primeiro realizou-se uma revisão bibliográfica exploratória em conjunto com a definição do problema de pesquisa.

A partir da pesquisa exploratória fez-se uma Revisão Bibliográfica Sistemática (RBS) sobre SGI para levantar os principais estudos e lacunas. Para a realização da RBS utilizou-se como referência o método proposto por Confoto, Amaral e Silva (2011), pois é voltado para a área de gestão de operações. A busca usando termos como "ISO", "OHSAS", "integrated management system" e algumas variações desse último termo foram feitas nas bases Web of Science e Scopus. Na RBS foi possível perceber a falta de estudos sobre Modelo de Maturidade em SGI e em virtude disso foi realizada uma revisão bibliográfica sobre Modelo de Maturidade.

Logo após, houve o desenvolvimento conceitual com a elaboração da ferramenta para avaliação da maturidade de intregração dos sistemas de gestão. A ferramenta foi avaliada por dois especialistas acadêmicos e profissionais da indústria que trabalham em empresas onde há a integração de ao menos dois sistemas de gestão. De acordo com sugestões dadas surgiu a versão final. 


\subsection{Estrutura da Dissertação}

A dissertação está dividida em 5 capítulos.

O Capítulo 1 apresenta a contextualização, justificativa, objetivo, contribuição da pesquisa, questão de pesquisa e método de desenvolvimento.

O Capítulo 2 realiza uma revisão bibliográfica sobre sistemas de gestão e modelos de maturidade. Nele, aproveita-se para apresentar alguns resultados sobre a revisão exploratória e a Revisão Bibliográfica Sistemática (RBS) realizada a respeito do SGI. Maiores detalhes sobre ambas as revisões serão encontradas no capítulo seguinte.

O Capítulo 3 expõe o método de pesquisa e o Capítulo 4 apresenta a ferramenta de avaliação do grau de maturidade em SGI. Para finalizar, o Capítulo 5 foca nas conclusões. 


\section{Revisão Bibliográfica}

\subsection{Sistemas de Gestão}

Os sistemas de gestão surgiram como forma de auxiliar na melhoria contínua das organizações, colaborando com a formação de uma estrutura que contribui com o gerenciamento de uma área específica. Há diferentes tipos de sistemas de gestão, entre eles podemos citar o Sistema de Gestão da Qualidade - ISO 9001, o Sistema de Gestão Ambiental - ISO 14001, o Sistema de Segurança e Saúde Ocupacional - OHSAS 18001 e o Sistema de Gestão de Responsabilidade Social - NBR 16001. Os três primeiros citados são os sistemas padronizados mais conhecidos, mas há muitos outros incluindo sistemas de gestão específicos para determinados setores como a ISO/TS 16949 (Sistema de Gestão da Qualidade voltada para o setor automobilístico) e a ISO 22000 (Sistema de Gestão de Segurança Alimentar). A seguir são apresentadas informações detalhadas sobre os quatro sistemas de gestão que serviram de base para a elaboração do presente trabalho. A escolha deles se deu pelo fato de serem amplamente conhecidos como também pelo fato de contribuirem no aspecto da sustentabilidade.

\subsubsection{Sistema de Gestão da Qualidade - ISO 9001}

A sigla ISO (International Organization for Standardization - Organização Internacional para Padronização) é uma organização não governamental que surgiu na Suíça, responsável pelo desenvolvimento de uma grande quantidade de normas que abrange uma variedade de áreas. A ISO 9001 é uma das normas mais conhecidas mundialmente elaborada pela ISO e que teve sua primeira versão em 1987, passando por três revisões ocorridas nos anos de 1994, 2000 e 2008. Ao longo dessas revisões, um alinhamento maior entre a ISO 9001 e as demais normas foi promovido.

A ISO 9001 faz parte das normas da série ISO 9000, a qual é composta pela ISO 9000:2005 - Sistema de Gestão da Qualidade - Fundamentos e Vocabulário; ISO 9001:2008 - Sistema de Gestão da Qualidade - Requisitos; e ISO 9004:2010 - Gestão para o Sucesso Sustentado de uma Organização - Uma Abordagem da Gestão da Qualidade (CARPINETTI; MIGUEL; GEROLAMO, 2011). A única das três normas apresentadas que atualmente pode 
ser certificada é a ISO 9001:2008, a qual designamos nesta dissertação por apenas ISO 9001, omitindo o complemento 2008 que representa o ano de sua publicação.

O modelo de sistema de gestão da qualidade estabelece cinco requisitos que são interrelacionados, sendo eles: Sistema da Qualidade; Responsabilidade da Direção; Gestão de Recursos; Realização do Produto; e Medição, Análise e Melhoria. Esses requisitos permaneceram inalterados durante a revisão sofrida entre as versões de 2000 e 2008 (CARPINETTI; MIGUEL; GEROLAMO, 2011).

A ISO 9001 especifica requisitos para um sistema de gestão da qualidade, mas não estabelece requisitos para produtos, embora esse último deva existir e ser seguido de forma complementar. Com base nisso, é possível concluir que a certificação não garante a qualidade do produto, mas sim a gestão do processo de realização do produto. $\mathrm{O}$ foco dessa norma está em atender aos requisitos dos clientes. Além disso, é conveniente que sua adoção surja em consequência de uma decisão estratégica, sendo a participação e apoio da alta direção fundamental (ASSOCIAÇÃO BRASILEIRA DE NORMAS TÉCNICAS, 2008).

Em uma pesquisa feita no Canadá com empresas certificadas em ISO 9001 e/ou ISO 14001 foi revelado que as principais armadilhas na implantação desses sistemas de gestão podem ser agrupado em 5 principais categorias: inapropriada ou excessiva documentação; falta de retorno e acompanhamento do sistema; busca por certificação com foco na área comercial; recursos insuficientes e externalização do processo de implantação (BOIRAL, 2011).

Com relação a números, em 2011 havia um total de 1.111 .698 certificados ISO 9001 espalhados por 180 países, os quais foram emitidos tanto durante o ano de 2011 como nos anos anteriores e ainda se encontravam válidos. A Tabela 1 apresenta os países que mais possuíam certificado ISO 9001 no ano de 2011, enquanto a Tabela 2 mostra os países que mais apresentaram crescimento de certificações em 2011, sendo que em ambos os casos o Brasil ficou em $9^{\circ}$ lugar. O Gráfico 1 demonstra a evolução de certificações da ISO 9001 no Brasil, ou seja, o quanto havia por ano de certificados no país. O Gráfico 2 apresenta a evolução de certificações da ISO 9001 no mundo todo (ISO, 2012b). 
Tabela 1 - Relação dos 10 países que mais possuem certificados ativos ISO 9001 no ano de 2011.

Fonte: ISO (2012b)

\begin{tabular}{|c|c|c|}
\hline \multicolumn{3}{|c|}{$N^{\text {o }}$ certificações ISO 9001 por País - 2011 } \\
\hline 1 & China & 328.213 \\
\hline 2 & Itália & 171.947 \\
\hline 3 & Japão & 56.912 \\
\hline 4 & Espanha & 53.057 \\
\hline 5 & Alemanha & 49.540 \\
\hline 6 & Reino Unido & 43.564 \\
\hline 7 & Índia & 29.574 \\
\hline 8 & França & 29.215 \\
\hline 9 & Brasil & 28.325 \\
\hline 10 & República da Coréia & 27.284 \\
\hline
\end{tabular}

Tabela 2 - Relação dos 10 países que apresentaram maior crescimento no $\mathrm{n}^{\circ}$ de certificados ISO 9001 no ano de 2011.

Fonte: ISO (2012b)

\begin{tabular}{|c|c|c|}
\hline \multicolumn{3}{|c|}{ Aumento do No de certificações ISO 9001 por País - 2011 } \\
\hline 1 & Itália & 33.055 \\
\hline 2 & China & 31.175 \\
\hline 3 & Romênia & 3.205 \\
\hline 4 & Vietnã & 2.743 \\
\hline 5 & República da Coréia & 2.506 \\
\hline 6 & Malásia & 2.143 \\
\hline 7 & Colômbia & 2.099 \\
\hline 8 & Singapura & 1.710 \\
\hline 9 & Brasil & 1.662 \\
\hline 10 & Sérvia & 1.078 \\
\hline
\end{tabular}

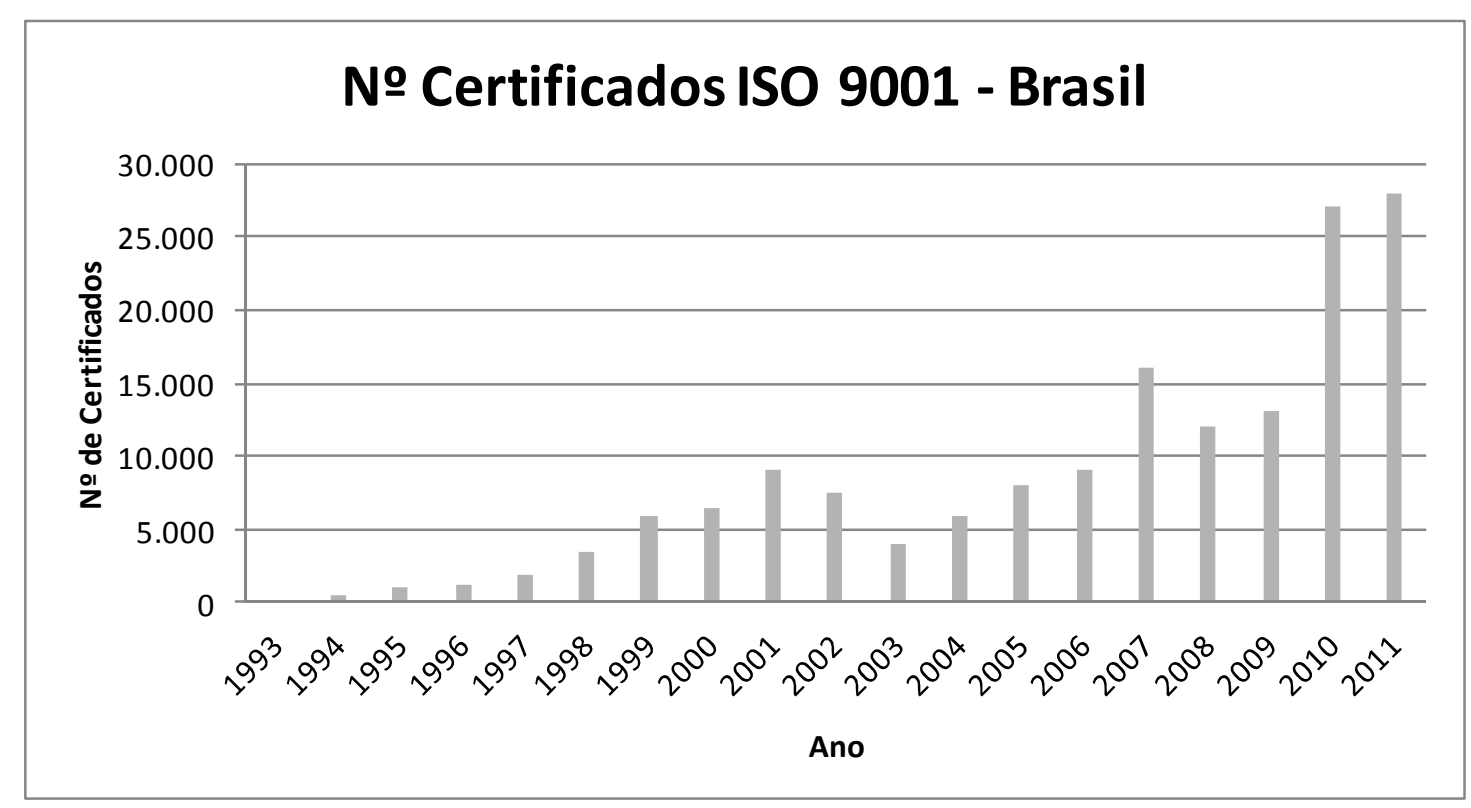

Gráfico 1 - Número de certificados ISO 9001 (Brasil) / Ano.

Fonte: ISO (2012b) 


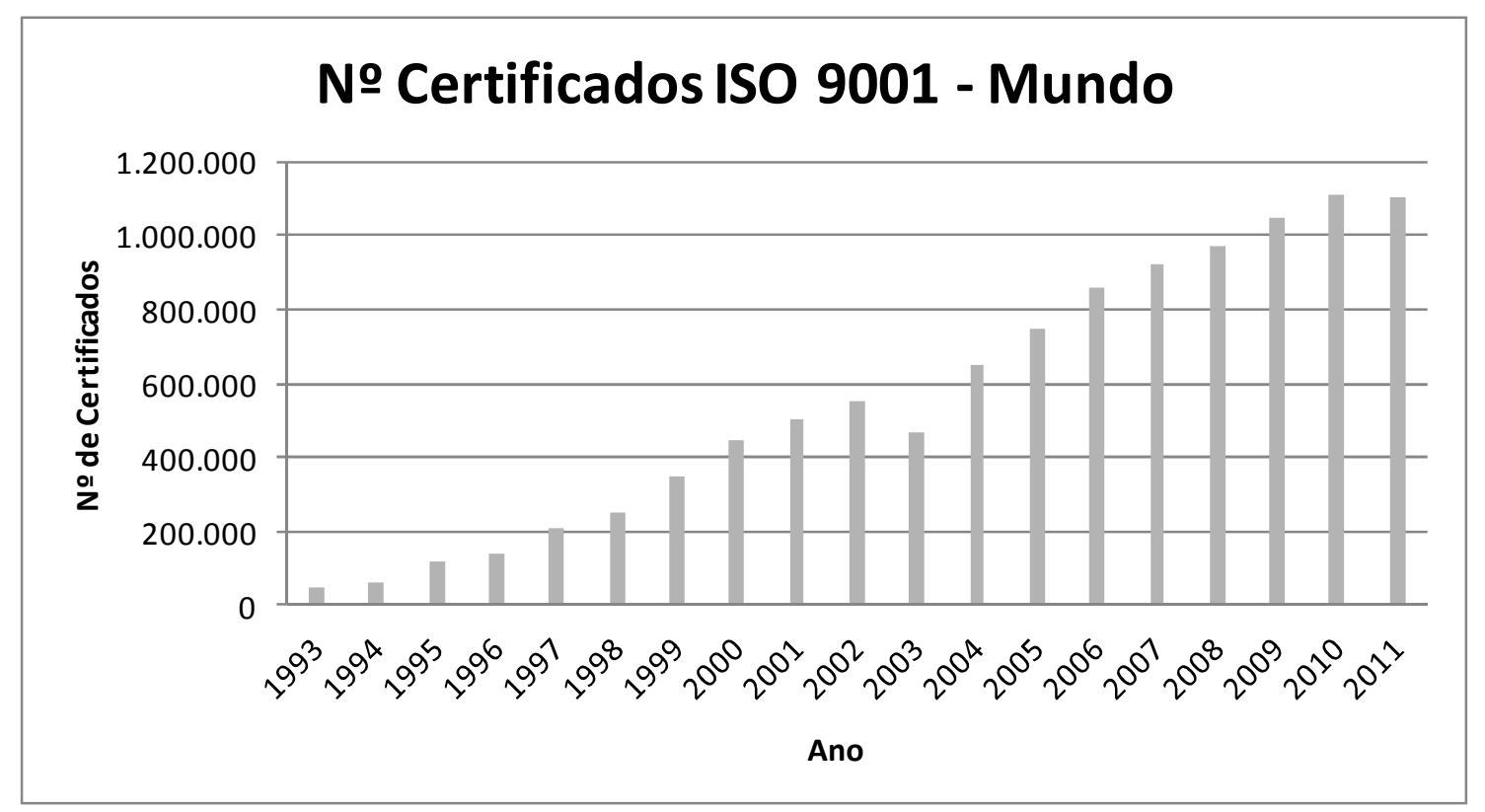

Gráfico 2 - Número de certificados ISO 9001 (mundo) / Ano.

Fonte: ISO (2012b)

A ISO 9001 versão de 2008 está dividida de acordo com os seguintes itens: Escopo; Referência normativa; Termos e definições; Sistema de gestão da qualidade; Responsabilidade da direção; Gestão de recursos; e Realização do produto; Medição, análise e melhoria.

\subsubsection{Sistema de Gestão Ambiental - ISO 14001}

O objetivo das normas de gestão ambiental é fornecer elementos de um Sistema de Gestão Ambiental (SGA) eficaz que possa ser integrado com outros requisitos de gestão, de forma a obter ganhos econômicos e ambientais (ASSOCIAÇÃO BRASILEIRA DE NORMAS TÉCNICAS, 2004).

A primeira versão da ISO 14001 surgiu em 1996 e sua primeira revisão ocorreu em 2004, sendo a versão atualmente utilizada. A ISO 14001 não fornece requisitos absolutos, ou seja, ela não estabelece parâmetros mínimos, sendo que para ser certificada a empresa precisa estar em conformidade com a lei e demonstrar que está buscando a melhoria contínua dos seus processos. Pode ocorrer de duas empresas com atividades parecidas serem certificadas, embora possuam níveis diferentes de desempenho ambiental. A ISO 14001 não inclui requisitos específicos de qualidade, segurança e saúde ocupacional, entre outros, mas ela permite esse alinhamento com outros sistemas de gestão (ASSOCIAÇÃO BRASILEIRA DE NORMAS TÉCNICAS, 2004). 
A norma introduz os conceitos de aspecto e impacto ambiental. $\mathrm{O}$ aspecto é tudo que pode interagir com o meio ambiente e impacto é a modificação causada no meio ambiente, podendo essa modificação ser benéfica ou maléfica (ASSOCIAÇÃO BRASILEIRA DE NORMAS TÉCNICAS, 2004).

No ano de 2011, a ISO 14001 contava com 267.457 certificações distribuídas em 158 países, o que representou um crescimento em torno de $6 \%$ com relação a $2010(+15.909)$. A Tabela 3 apresenta os países que mais possuíam certificado ISO 14001 no ano de 2011, enquanto a Tabela 4 contém os países que mais apresentaram crescimento nessa norma no ano de 2011. Em ambos os casos o Brasil não se encontra entre os 10 países mais representativos. O Gráfico 3 demonstra a evolução de certificações ISO 14001 no Brasil e o Gráfico 4 apresenta a evolução de certificações ISO 14001 no mundo (ISO, 2012b).

Tabela 3 - Relação dos 10 países que mais possuem certificados ativos ISO 14001 no ano de 2011.

Fonte: ISO (2012b)

\begin{tabular}{|c|c|c|}
\hline \multicolumn{3}{|c|}{ No certificações ISO 14001 por País - 2011} \\
\hline 1 & China & 81.993 \\
\hline 2 & Japão & 30.397 \\
\hline 3 & Itália & 21.009 \\
\hline 4 & Espanha & 16.341 \\
\hline 5 & Reino Unido & 15.231 \\
\hline 6 & República da Coréia & 10.925 \\
\hline 7 & Romênia & 9.557 \\
\hline 8 & França & 7.771 \\
\hline 9 & Alemanha & 6.253 \\
\hline 10 & Estados Unidos & 4.957 \\
\hline
\end{tabular}

Tabela 4 - Relação dos 10 países que apresentaram maior crescimento de certificados no $n^{\circ}$ de ISO 14001 no ano de 2011.

Fonte: ISO (2012b)

\begin{tabular}{|c|c|c|}
\hline \multicolumn{3}{|c|}{ Aumento do $\mathrm{N}^{0}$ de certificações ISO 14001 por País - 2011} \\
\hline 1 & China & 12.209 \\
\hline 2 & Itália & 3.945 \\
\hline 3 & França & 2.520 \\
\hline 4 & Romênia & 2.139 \\
\hline 5 & República da Coréia & 1.244 \\
\hline 6 & Reino Unido & 885 \\
\hline 7 & Singapura & 684 \\
\hline 8 & Canadá & 550 \\
\hline 9 & Estados Unidos & 550 \\
\hline 10 & Thailândia & 465 \\
\hline
\end{tabular}




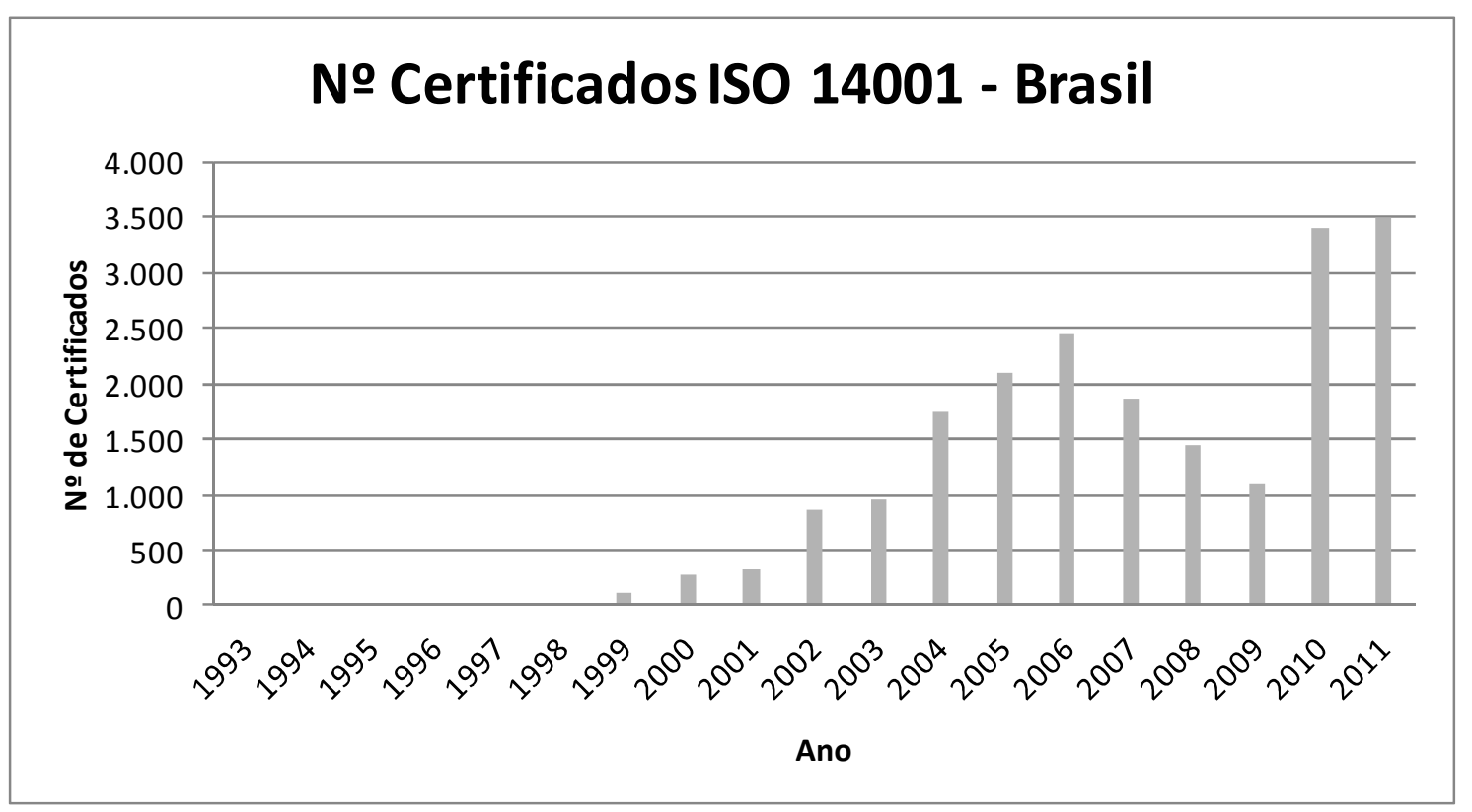

Gráfico 3 - Número de certificados ISO 14001 (Brasil) / Ano.

Fonte: ISO (2012b)

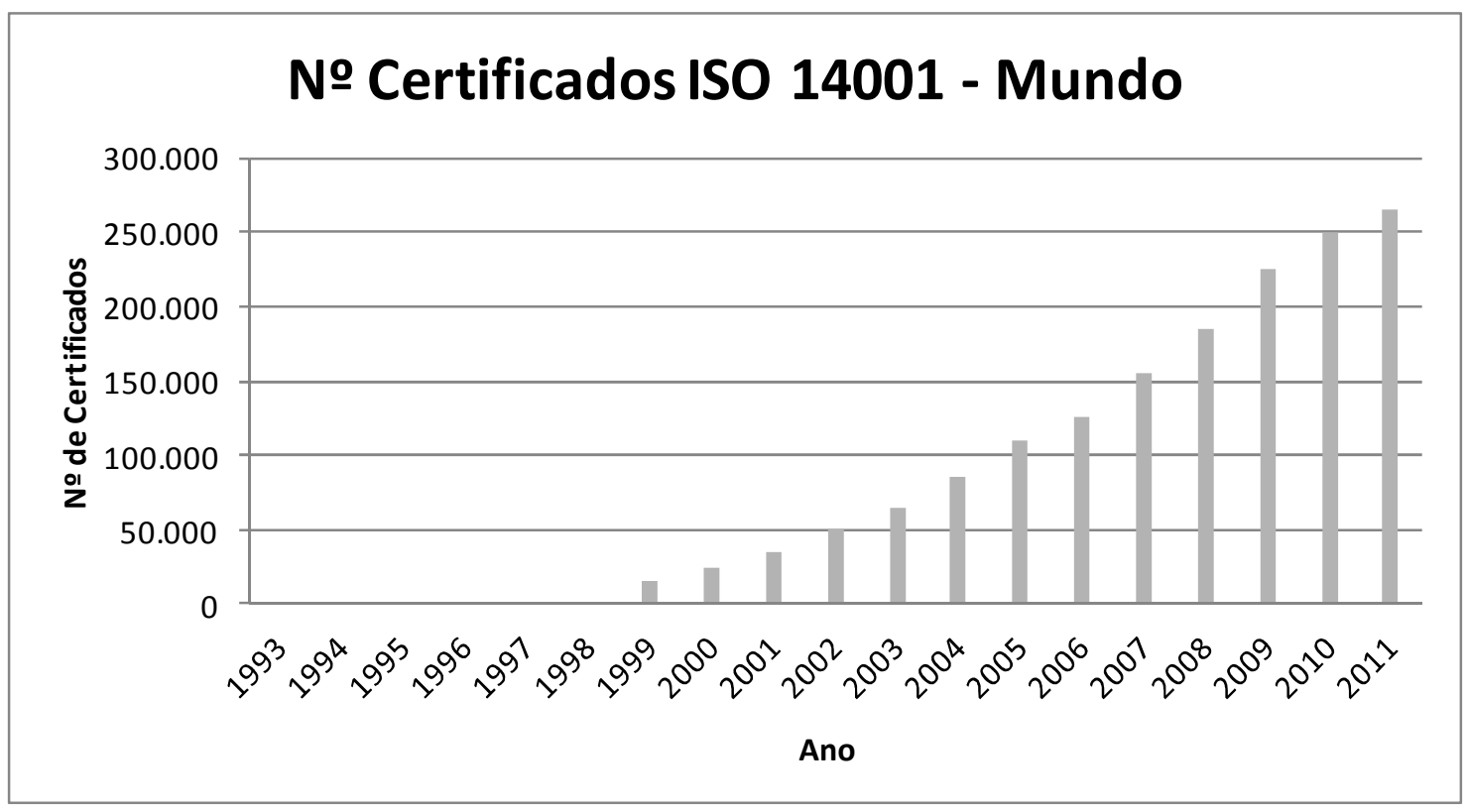

Gráfico 4 - Número de certificados ISO 14001 (mundo) / Ano Fonte: ISO (2012b)

A ISO 14001 versão 2004 conta com a seguinte divisão: Objetivo; Referência normativa; Termos e definições; e Requisitos e sistema da gestão ambiental. 


\subsubsection{Sistema de Segurança e Saúde Ocupacional - OHSAS 18001}

A OHSAS 18001 é uma norma internacional criada com o auxílio de organismos nacionais de normalização, certificação, de acreditação, institutos de segurança e saúde ocupacional, associações industriais, consultorias e agências governamentais, sendo que seu secretariado fica a cargo da BSI. A OHSAS 18001 objetiva auxiliar as organizações na gestão da Segurança e Saúde Ocupacional (SSO), mas não interfere nas obrigações legais e também não pretende promover a criação de barreiras comerciais não tarifárias. Sua primeira versão foi publicada em 1999 e revisada em 2007. A sigla OHSAS (Occupational Health and Safety Assessment Series) significa Série de Avaliação de Segurança e Saúde Ocupacional. Ela foi desenvolvida para ser compatível com a ISO 9001 e ISO 14001; e assim como essas outras normas, a OHSAS 18001 é certificável e não fornece requisitos absolutos (BRITISH STANDARDS INSTITUTION, 2007).

O propósito da OHSAS 18001 consiste em especificar requisitos para o Sistema de Gestão em Segurança e Saúde Ocupacional de forma a permitir o controle de seus riscos e melhorar seu desempenho em termos de SSO (BRITISH STANDARDS INSTITUTION, 2007).

No Brasil, de acordo com o Anuário Brasileiro de Proteção de 2012, existe cerca de 748 empresas certificadas em OHSAS 18001. Outro ponto importante, é que ABNT lançou recentemente a NBR 18801, a qual é uma versão da OHSAS 18001 sem grandes alterações principalmente no que tange o conteúdo normativo (REVISTA PROTEÇÃO, 2012).

A OHSAS 18001 versão de 2007 está estruturada da seguinte forma: Escopo; Referências; Termos e definições; e Requisitos para o sistema de gestão de saúde e segurança ocupacional.

\subsubsection{Sistema de Gestão de Responsabilidade Social - NBR 16001}

A NBR 16001 é uma norma brasileira de Sistema de Gestão de Responsabilidade Social lançada em 2004 e revista em 2012. Essa norma é certificável nacionalmente. Assim como as demais normas, a NBR 16001 não garante que a organização seja socialmente responsável, mas sim que ela possui um sistema de gestão de responsabilidade social (ASSOCIAÇÃO BRASILEIRA DE NORMAS TÉCNICAS, 2012).

De acordo com a própria norma, responsabilidade social refere-se à responsabilidade da organização com a sociedade e o meio ambiente, estando esse conceito intimamente relacionado com o desenvolvimento sustentável, embora não seja a mesma coisa. Além disso, a conformidade com essa norma não acarreta a conformidade com a ISO 26000 - Diretrizes 
sobre Responsabilidade Social, embora a NBR 16001 possa auxiliar o processo de implantação de algumas diretrizes da ISO 26000 (ASSOCIAÇÃO BRASILEIRA DE NORMAS TÉCNICAS, 2012). É importante ressaltar que a ISO 26000 não tem caráter certificatório, enquanto que a NBR 16001 pode ser certificada. Outro detalhe importante é que a primeira tem abrangência internacional por se tratar de uma Norma da série ISO, enquanto a segunda tem abrangência nacional apenas. No entanto, para o escopo desse trabalho, optou-se por utilizar a NBR 16001 ao invés da ISO 26000 uma vez que a primeira apresenta requisitos para o sistema de gestão de responsabilidade social e a segunda se baseia nas diretrizes.

A iniciativa de certificação da NBR 16001 ocorreu no ano de 2006, sendo algo inédito no mundo. O INMETRO foi o primeiro órgão governamental a coordenar a avaliação de uma norma de gestão de responsabilidade social. Em 2007 foi emitido o primeiro certificado e em Abril de 2013 no Brasil havia 20 empresas certificadas e 3 organismos de certificação (INMETRO, 2013).

A NBR 16001 foi publicada em 2012 e segue a seguinte ordem de tópicos: Escopo; Termos e definições; e Requisitos do sistema de gestão da responsabilidade social.

\subsubsection{Compatibilidade entre as normas}

A seguir é apresentada a Tabela 5 onde consta alguns dos principais itens das normas e sua compatibilidade, os quais serviram de base para a ferramenta elaborada.

Tabela 5 - Comparação entre os itens das normas

\begin{tabular}{|l|c|c|c|c|}
\hline & ISO9001:2008 & ISO14001:2004 & OHSAS18801:2007 & NBR16001:2012 \\
\hline Escopo/Objetivo & 1 & 1 & 1 & 1 \\
\hline Referência normativa & 2 & 2 & 2 & 3 \\
\hline Termos e definiç̃̃es & 3 & 3 & 4.1 & 3.1 \\
\hline Requisitos gerais & 4.1 & 4.1 & $4.4 / 4.5$ & $3.4 / 3.5$ \\
\hline Documentação & 4.2 & $4.4 / 4.5$ & 4.4 & 3.6 \\
\hline $\begin{array}{l}\text { Comprometimento da } \\
\text { direção }\end{array}$ & 5.1 & $4.4 / 4.6$ & 3.3 & 3.2 \\
\hline Política & 5.3 & 4.2 & 4.3 & 3.3 \\
\hline Planejamento & 5.4 & 4.3 & 4.4 & 3.4 \\
\hline Comunicação & 5.5 & 4.4 & 4.4 & 3.3 .7 \\
\hline Recursos & 6 & 4.4 & 4.5 & 3.4 \\
\hline $\begin{array}{l}\text { Implementação e } \\
\text { operacionalização }\end{array}$ & 7 & 4.4 & 4.5 .5 & 3.6 \\
\hline $\begin{array}{l}\text { Medição, análise e } \\
\text { melhoria }\end{array}$ & 8 & 4.5 & 4.5 .3 & 3.6 .3 \\
\hline Auditoria & 8.2 .2 & 4.5 .5 & & \\
\hline $\begin{array}{l}\text { Controle de não } \\
\text { conformidade }\end{array}$ & 8.3 & $4.4 .7 / 4.5 .3$ & & \\
\hline
\end{tabular}




\subsection{Sistemas de Gestão Integrados (SGI)}

Um sistema é um conjunto de recursos e processos utilizados para alcançar um objetivo desejado como, por exemplo, a criação de um produto. Esse produto pode ser algo tangível, intangível ou uma combinação de ambos (KARAPETROVIC; WILLBORN, 1998).

Segundo a ISO (2008), um sistema de gestão tem como objetivo auxiliar na gestão de riscos relacionados com a entrega de produtos e serviços aos clientes e stakeholders. Além disso, essas normas colaboram para a promoção da melhoria contínua na organização. Entre os principais componentes de um sistema de gestão estão: visão e estratégia, metas e objetivos, clientes e outros stakeholders, produto e mercado, estrutura e recursos, produto e processo de realização do produto, e processos de suporte.

O surgimento dos sistemas integrados ocorre quando dois sistemas se unem de forma que resulte a perda de independência de um deles ou de ambos, porém sem abrir mão de suas identidades individuais. Essa integração varia com relação ao alcance e controle (KARAPETROVIC; WILLBORN, 1998).

Toda organização tem um sistema de gestão através do qual são estabelecidos objetivos. Porém, nem sempre esse sistema de gestão é documentado. Conforme a organização cresce, essa falta de clareza pode afetar o sucesso da mesma. Para estabelecer uma abordagem de sistema, é preciso compreender como o sistema trabalha e como o sucesso é mensurado (ISO, 2008).

Na visão de Beckmerhagen et al. (2003), entende-se por integração a combinação de partes separadas dentro de um todo. No caso da integração de sistemas de gestão pode-se definí-la como o processo de unir diferentes funções específicas dos sistemas de gestão dentro de um único sistema, que passa a ser chamado SGI.

Segundo o levantamento feito por López-Fresno (2010), foi nos anos 90 que começou a se discutir a questão da integração de sistemas de gestão. O que se percebe é que o foco da integração está centrado nas normas relacionadas à gestão da qualidade, ambiental e saúde e segurança, necessitando se estender esse escopo procurando incluir normas específicas.

Para Zutshi e Sohal (2005) e López-Fresno (2010), o SGI é uma das principais formas de garantir a sobrevivência da organização e aumentar a rentabilidade através da economia de tempo, dinheiro e recursos. Além disso, ele ajuda na tomada das melhores decisões levando em consideração a política e estratégia corporativa.

Wilkinson e Dale (2002) citam a existência de basicamente dois níveis de integração quando se fala em SGI. Um deles busca apenas o alinhamento das estruturas das normas, 
tendo o objetivo maior de reduzir custos apenas. Já a outra forma é mais completa, buscando uma integração onde se tenham ganhos não apenas financeiros, mas em termos de gestão do desempenho como um todo.

O livro "The Integrated Use of Management System Standards", lançado pela ISO, auxilia a empresa no processo de integração. De acordo com ele, é preciso primeiro a liderança se engajar para que possa conduzir a integração, levando em consideração seus benefícios e custos. Em seguida, é importante determinar o escopo da integração, ou seja, essa é a etapa de verificar quais normas serão integradas e em que ordem. A próxima etapa é o planejamento da integração, seguido da fase de levantamento dos requisitos a serem integrados. Depois que se sabem quais são os requisitos, é importante incorporar os mesmos de forma integrada. A penúltima etapa consiste em manter e melhorar continuamente a integração. A última etapa estabelece que seja importante aplicar as lições aprendidas na organização para que se aprenda com a experiência adquirida. Esse livro deixa claro que ele não tem caráter de norma, ou seja, não serve a título de certificação, mas busca auxiliar no processo de integração de normas (ISO, 2008).

\subsubsection{Benefícios do SGI}

De acordo com Jørgensen, Remmen e Mellado (2006), ao longo do tempo a ISO tem procurado tornar suas normas mais compatíveis entre si. Porém, a questão da compatibilidade é um primeiro passo na integração das normas. Um nível mais alto de integração exige uma cultura de aprendizagem, a participação dos stakeholders e a melhoria contínua para trazer benefícios externos e contribuir com o desenvolvimento sustentável.

Diversos pesquisadores encontraram similaridades ao levantar os benefícios da integração. Um dos benefícios mais citados pela maioria deles foi a questão da diminuição de documentos, juntamente com a redução dos custos, melhora na comunicação, diminuição do número de auditorias, melhora na tomada de decisão e melhor utilização de recursos (LÓPEZFRESNO, 2010; SALOMONE, 2008; VITORELI, 2011; ZUTSHI; SOHAL, 2005). Outros benefícios destacados foram: facilidade de promover a melhoria contínua (SIMON; KARAPETROVIC; CASADESÚS, 2012b), melhora quanto à motivação das pessoas, tomadas de decisões mais orientadas para os clientes, mudança de cultura (LÓPEZ-FRESNO, 2010), maior alinhamento com o planejamento estratégico, visão holística ao invés de uma visão fragmentada das normas, maior comprometimento dos empregados, maior efetividade 
dos treinamentos que passam a abranger todas as normas de forma integrada (ZUTSHI; SOHAL, 2005), maior consistência dos sistemas de gestão e redução da burocracia (ISO, 2008), diminuição da chance de realização de atividades redundantes (ISO, 2008; VITORELI, 2011), além de canalizar esforços e melhorar a coordenação entre as áreas (VITORELI, 2011).

\subsubsection{Barreiras para a Integração dos Sistemas de Gestão}

Entre as principais barreiras relacionadas à integração dos sistemas de gestão levantadas por diferentes pesquisadores estão: priorizar uma determinada norma em detrimento das demais (JØRGENSEN; REMMEN; MELLADO, 2006; SALOMONE, 2008); apoio inadequado dos organismos certificadores (SALOMONE, 2008; ZENG; SHI; LOU, 2007); recursos humanos despreparados, desmotivados ou em quantidade insuficiente (SIMON; KARAPETROVIC; CASADESÚS, 2012b; ZENG; SHI; LOU, 2007; ZUTSHI; SOHAL, 2005); falta de uma cultura organizacional adequada e que apóie a integração (JØRGENSEN; REMMEN; MELLADO, 2006; ZENG; SHI; LOU, 2007); dificuldade de organizar o SGI, dificuldade de integração das normas (SALOMONE, 2008); falta de apoio da alta administração, falta de suporte tecnológico (SIMON; KARAPETROVIC; CASADESÚS, 2012b); e falta de alinhamento com o planejamento estratégico (ZUTSHI; SOHAL, 2005).

Essas barreiras devem ser levadas em consideração quando se propõe a integração, pois elas podem prejudicar a utilização das normas, não trazendo os benefícios esperados. Outro ponto interessante é que a maioria dos aspectos abordados anteriormente foi levantada por mais de um autor, ou seja, eles merecem atenção especial.

\subsubsection{Recomendações para se Evitar Falhas na Integração dos Sistemas de Gestão}

De acordo com López-Fresno (2010), é importante as empresas estarem cientes das dificuldades que enfrentarão no momento da implantação do SGI, pois somente assim poderão trabalhar para evitar o insucesso. Entre as recomendações levantadas para evitar dificuldades na implantação do SGI estão: garantir apoio da alta administração, integrar auditorias, fornecer treinamento, estabelecer uma boa comunicação, garantir recursos adequados, contar com uma cultura que esteja disposta a colaborar, contar com um modelo de integração flexível e que a base desse modelo esteja alicerçada no ciclo PDCA (Plan-Do- 
Check-Act). A autora completa que essas recomendações podem variar de importância de organização para organização, mas que independente disso, seguí-las fará com que se diminua a chance de fracasso. Além disso, o SGI deveria contemplar todas as normas, não importando se são obrigatórias ou não, bem como se são gerais ou setoriais. Ela destaca que atualmente o foco tem sido na integração das normas de qualidade, ambiental, e saúde e segurança, mas em seu estudo de caso se deparou com a realidade de uma empresa que vai além dessa integração mais comumente encontrada e que integra todos os seus sistemas de gestão, o que contribui para o aumento da sua competitividade.

Zutshi e Sohal (2005) também fazem algumas recomendações para as empresas que procuram a integração. Uma das questões mais importantes é conseguir o apoio e o comprometimento da alta administração, pois sem isso todo esforço estará perdido. É importante também realizar revisões das metas da companhia para que as mesmas estejam enquadradas nas necessidades do SGI. É válido designar uma pessoa dentro da organização que seja da média ou alta administração e que se torne o responsável pela implantação do SGI, pois só assim as pessoas perceberão que se trata de algo realmente importante. Além disso, é necessário fornecer treinamento adequado para todos os funcionários; dar aos empregados conhecimento para trabalharem na integração; contar com um sistema de documentação controlado; auditar todos os sistemas e acompanhar de perto os desperdícios. A questão cultural é outro ponto relevante, bem como a tentativa de evitar confrontos pessoais. É igualmente importante trabalhar em parceria com os fornecedores e desenvolver uma comunicação forte.

\subsubsection{Panorama Geral das Pesquisas Focadas em SGI}

De acordo com o levantamento feito na bibliografia, é nítido o aumento que houve em termos de publicações sobre SGI de 2010 para frente conforme pode ser visto no Gráfico 5. Vale a pena destacar que os dados de 2013 no gráfico a seguir se referem ao levantamento feito até Dezembro, porém esse número pode sofrer alteração porque é natural que artigos de 2013 venham a ser indexados ainda durante os primeiros meses de 2014. Maiores informações sobre como foi realizado esse levantamento serão apresentados no Capítulo 3, onde é explicado em detalhe como foi feita a pesquisa exploratória e a Revisão Bibliográfica Sistemática (RBS) sobre SGI que deram origem a esses resultados. 


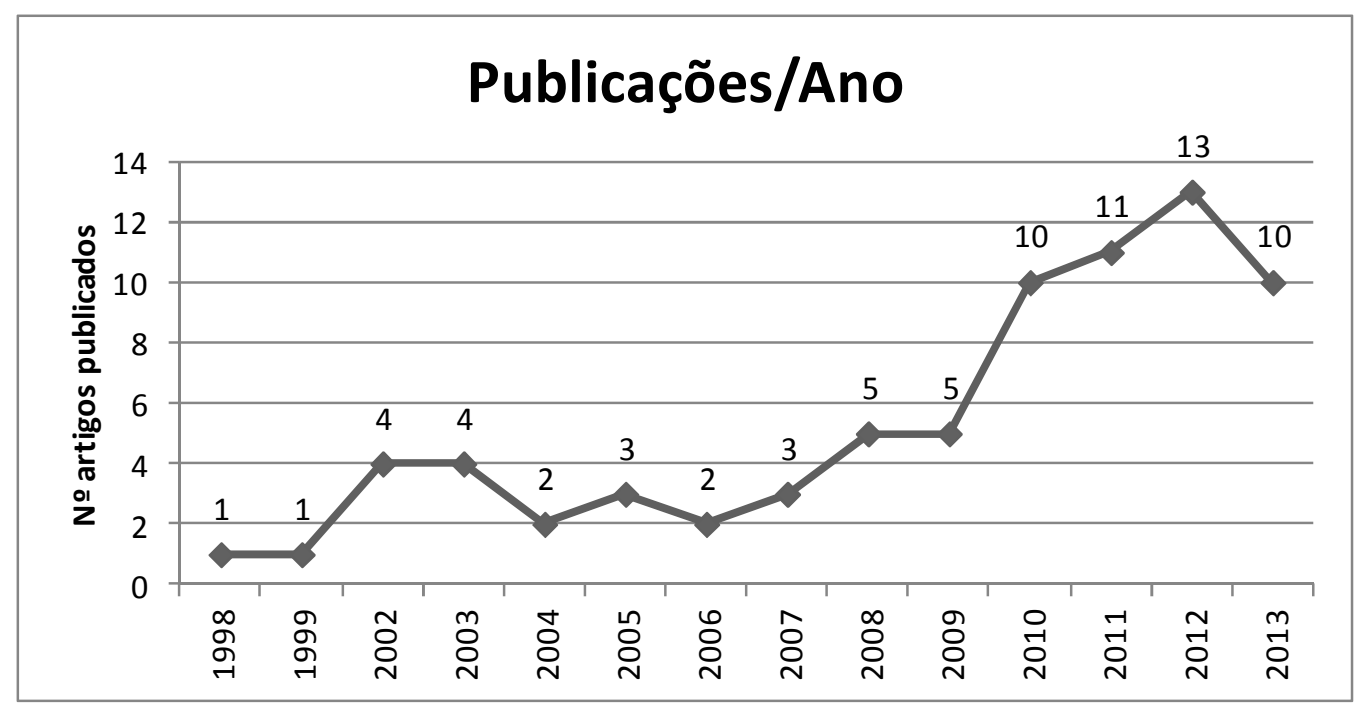

Gráfico 5 - Número publicações ao ano.

Com relação aos países que mais tem publicado e pesquisado sobre o assunto estão Espanha, seguida por Brasil, China, Portugal e Canadá conforme demonstra o Gráfico 6. O Brasil vem em segundo lugar, mas é preciso ter cuidado nessa análise, uma vez que apenas uma publicação foi feita em revista internacional. Além disso, apenas três das oito publicações brasileiras foram levantadas através da pesquisa bibliográfica sistemática, enquanto as demais foram encontradas através de pesquisa exploratória realizada em congressos nacionais e banco de teses.

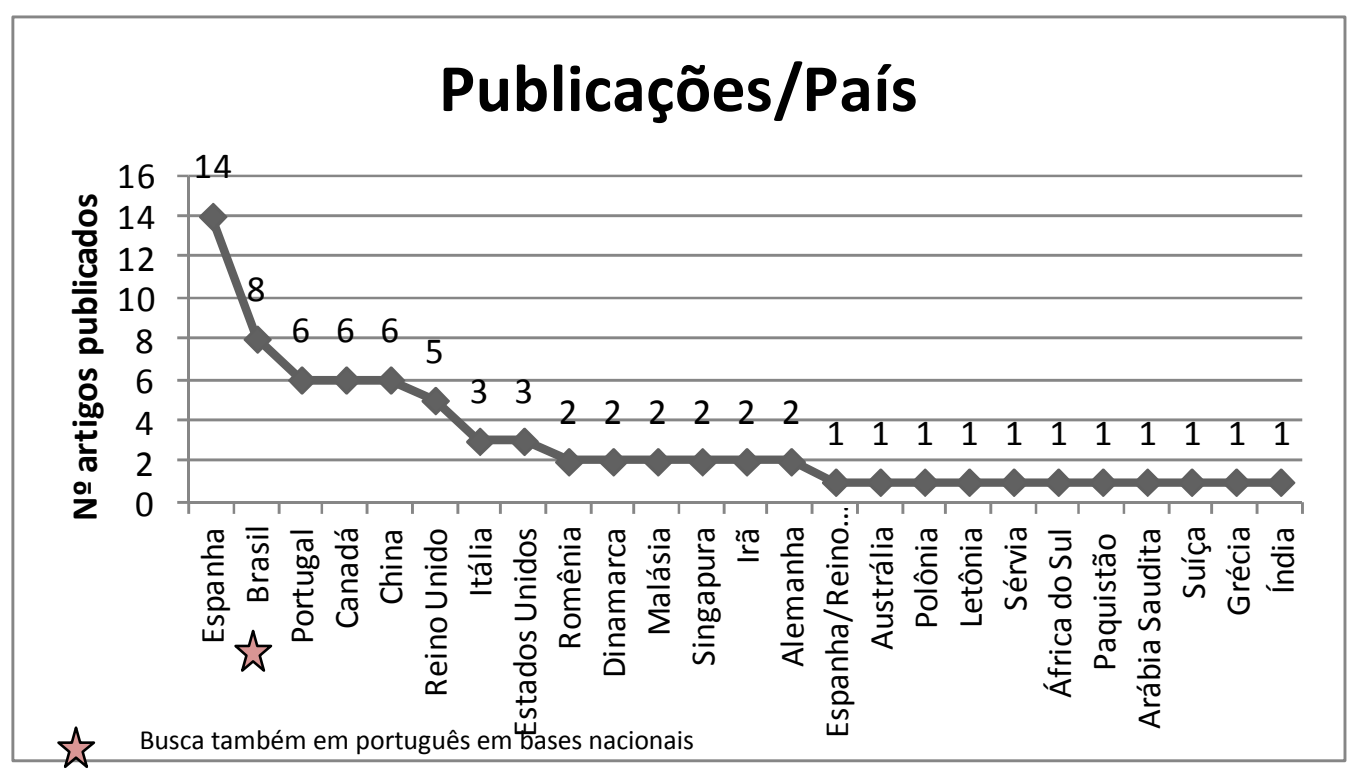

Gráfico 6 - Número publicações por país. 
Com relação ao método, a maior parte das pesquisas feitas utilizou survey, onde um questionário estruturado é enviado às empresas e as mesmas respondem sem terem sido visitadas pelo pesquisador. Outro método muito utilizado foi a pesquisa teórica e o estudo de casos conforme pode-se constatar pelo Gráfico 7. Um número muito pequeno de pesquisas nessa área fez uso do método conhecido como pesquisa-ação e de entrevistas com especialistas.

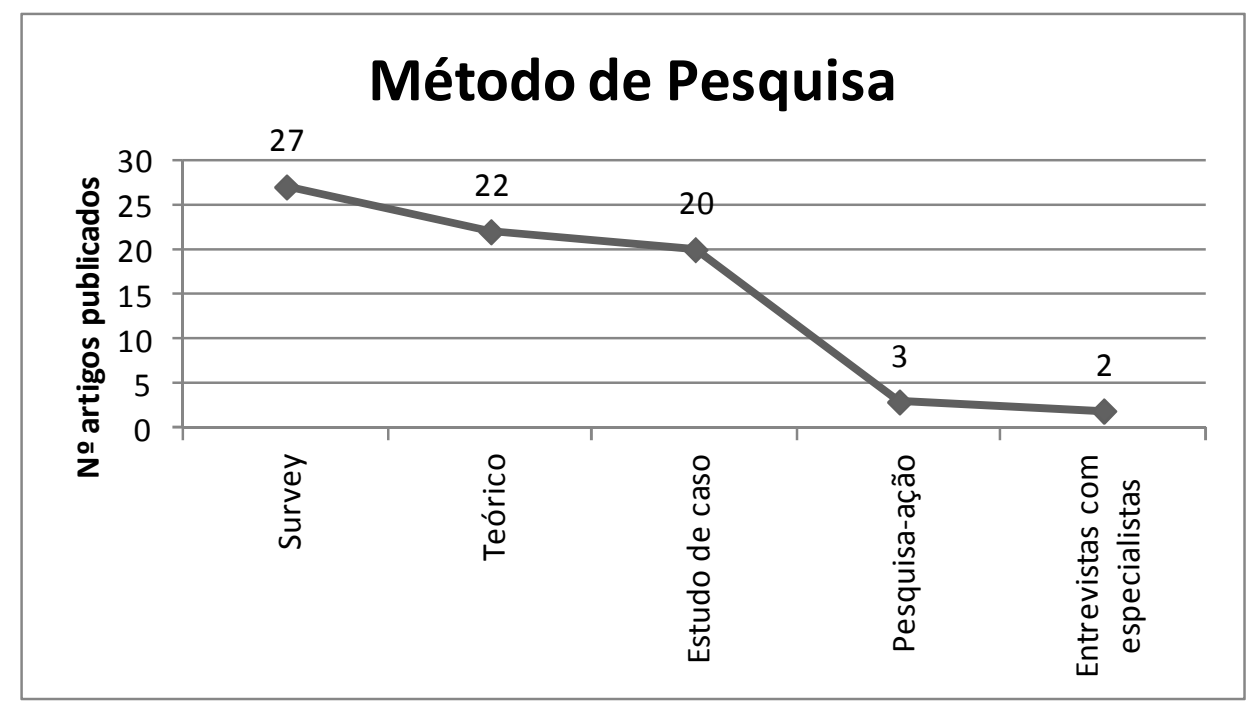

Gráfico 7 - Tipo de pesquisa.

Grande parte das pesquisas tem como foco os modelos para integração, bem como os benefícios, dificuldades e motivações para a integração dos sistemas de gestão conforme detalha o Gráfico 8. Vale a pena destacar que mesmo um artigo que possui como tema principal, por exemplo, benefícios, dificuldades e motivações, pode conter também informações sobre auditoria, e assim por diante. Ou seja, buscou-se classificar os artigos levando em consideração seu principal foco, embora cada artigo possa abordar outros temas. 


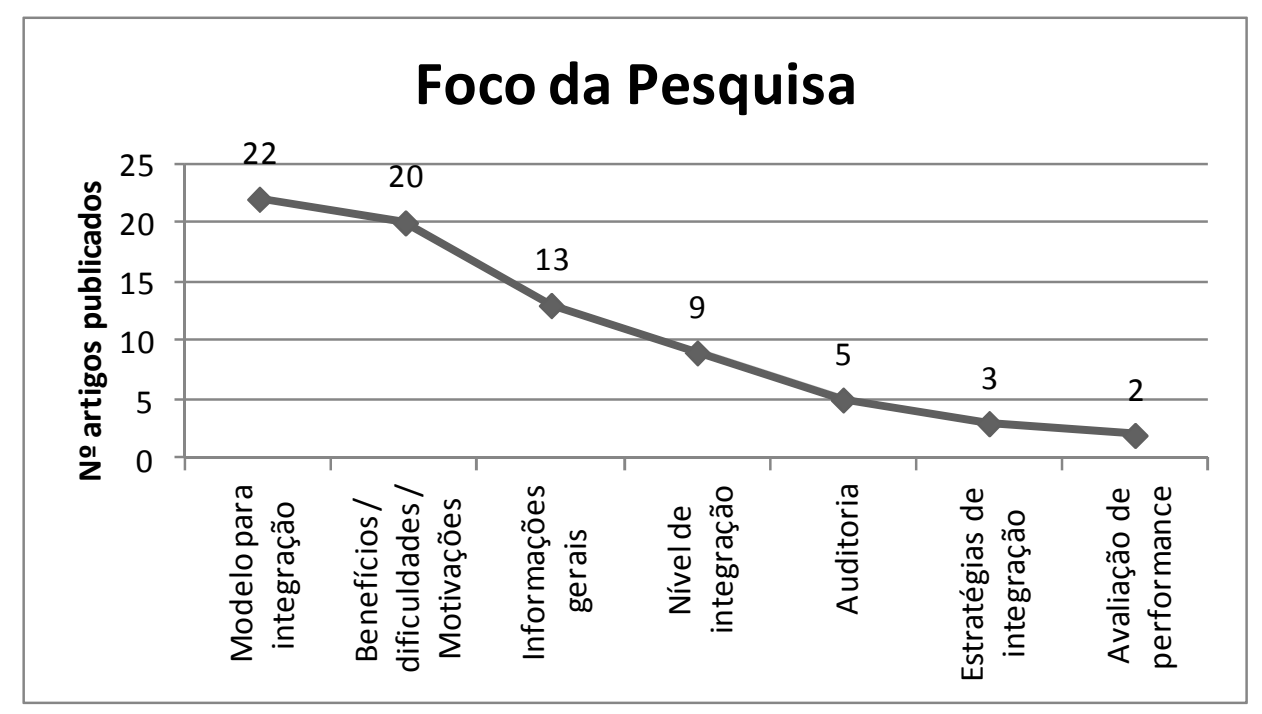

Gráfico 8 - Foco da pesquisa.

Os periódicos que mais publicaram artigos sobre o assunto foram: "Journal of Cleaner Production" com 11 publicações e "The TQM Jounal” com 8 publicações.

A Tabela 6 lista os autores que mais publicaram sobre o assunto. Dos 6 autores, os 5 primeiros são justamente os que costumam publicar em conjunto. Ou seja, nota-se que esses autores possuem um trabalho forte nessa área.

Tabela 6 - Principais autores que mais publicam sobre SGI por $\mathrm{n}^{\circ}$ de artigos publicados sobre SGI

\begin{tabular}{|c|c|}
\hline Autores & No Artigos \\
\hline Karapetrovic, S. & 16 \\
\hline Casadesus, M. & 11 \\
\hline Bernardo, M. & 7 \\
\hline Heras, I. & 6 \\
\hline Simon, A. & 5 \\
\hline Zeng, S.X. & 5 \\
\hline
\end{tabular}

\subsubsection{Principais Trabalhos sobre Níveis de Integração}

Há algumas publicações que abordam a questão do nível de integração como mostra o Gráfico 8, assim como há artigos que abordam essa questão de forma secundária. Abaixo seguem os principais artigos e um resumo das suas abordagens.

Um dos principais trabalhos encontrados sobre níveis de integração é o de Jørgensen, Remmen e Mellado (2006). Nesse trabalho, eles dividem a integração em 3 níveis: 
- Correspondente: A integração vista como correspondente ajuda a evitar problemas relacionados à burocracia e à confusão entre diferentes padrões, uma vez que procura a correspondência entre os diferentes padrões, podendo resultar na existência de um único manual, por exemplo.

- Coordenado/Coerente: A integração como coordenação é baseada no entendimento comum de processos genéricos tais como planejamento, política, implementação, verificação, etc.

- Estratético/Inerente: A integração estratégica é uma abordagem que auxilia a melhoria contínua real.

Salomone (2008) aborda a integração, porém, de uma forma superficial até mesmo porque esse não é o foco principal de seu estudo, se limitando a dizer se a integração é total, parcial ou se não existe integração. Em sua pesquisa, $73 \%$ das empresas revelaram integrar totalmente seus sistemas de gestão, $26 \%$ disseram integrar parcialmente, enquanto apenas $1 \%$ disse não haver integração. Nessa pesquisa, não é revelado qual o critério para a empresa avaliar se há integração ou não, fornecendo apenas a informação se o SGI, de modo geral, está integrado.

Simon, Karapetrovic e Casadesús (2012a, 2012b) possuem dois artigos que abordam a questão da integração. Em um deles relaciona o nível de integração com as dificuldades e benefícios provenientes da mesma. Nesse estudo, os níveis de integração foram agrupados em 4 categorias (procedimentos de controle; procedimentos estratégicos e operacionais; recursos de documentação; e recursos humanos); sendo que para cada item de cada uma das categorias foi avaliado se a integração era total, parcial ou se não havia integração naquele item (SIMON; KARAPETROVIC; CASADESÚS, 2012a). Na outra pesquisa avaliaram o nível de integração ao longo de 4 anos sob o aspecto dos seguintes elementos: recursos, documentação, metas e procedimentos. Assim como no estudo anterior dos autores, o nível de integração consistiu em avaliar se a integração era total, parcial ou se não havia integração (SIMON; KARAPETROVIC; CASADESÚS, 2012b).

No artigo publicado por Bernado et al. (2009), é apresentado um resumo dos principais autores que abordam a questão dos níveis de integração, fazendo um paralelo entre eles. Também é feito um estudo empírico sobre os níveis de integração, levando em consideração 3 aspectos: recursos humanos, documentação/metas e procedimentos. Para cada aspecto é verificado se a integração é total, parcial ou inexistente. Em outro trabalho, Bernardo et al. (2012a) continua abordando a questão da integração, mas para isso se utiliza dos conceitos usados no trabalho anterior de 2009. Nesse trabalho ele analisa se a ordem de implantação dos sistemas de gestão influencia no nível de integração. 
$\mathrm{O}$ artigo de Bernardo et al. (2012b) busca analisar se as dificuldades de integração interferem no nível de integração. O que se encontrou é que quando as empresas integram 3 normas diferentes, encontram dificuldades no processo de integração que interfere no nível de integração, mas essa mesma relação não é significativa se for levada em consideração a integração de 2 normas. Em outro trabalho, Simon et al (2011) assim como Bernardo et al. (2010) e Bernardo et al. (2011), abordam também os níveis de integração, mas sob o enfoque das auditorias.

$\mathrm{Na}$ pesquisa realizada por Satolo e Calarge (2008) no setor sucroalcooleiro, foram definidos diversos itens integráveis tais como: política, missão, valores, treinamento, controle/documentos, medição/monitoramento, reclamações, ações corretivas/preventivas, registros, auditorias internas, manual. Para cada item foi solicitado que a empresa desse uma nota de 1 a 5, sendo 1 para o item não integrado, 2 para a fase inicial de integração, 3 para fase intermediária, 4 para fase final de integração e 5 para totalmente integrado. Através desses dados, foi elaborado um gráfico radar mostrando como se encontrava cada um dos itens quanto a integração, sendo que os itens que se apresentavam totalmente integrados eram: política, manual, registros, treinamento, ações corretivas e preventivas, medição e monitoramento, e controle de documentos.

Asif et al. (2010) aborda o grau de integração sob a perspectiva estratégica, tática e operacional. Para cada uma dessas perspectivas é feito uma breve descrição dividindo cada um deles em integração completa, parcial e inexistente.

Nitu, Nitu e Solomone (2012) propõem um instrumento de avaliação do SGI, porém esse instrumento conta com um foco exclusivo nas seguintes normas: ISO 9001, ISO 14001, OHSAS 18001 e SA8000. O modelo é composto de 6 critérios principais: política, planejamento, implementação e operação, avaliação do desempenho, melhoria e revisão da gerência. Cada um desses critérios é desmembrado em subcritérios, os quais são representados por indicadores aonde a pontuação vai de 0 à 4 , onde 0 significa que o requisito não é aplicável e 4 significa que há evidências que mostram que o requisito foi amplamente atingido. Há indicadores que abordam exclusivamente aspectos de uma norma específica como é o caso do indicador "identificação e avaliação de todos os aspectos ambientais associados com os processos relacionados ao cliente". Esse tipo de indicador faz com que essa avaliação possa ser aplicada apenas nas empresas que possuem as 4 normas especificadas. Outro ponto observado é que os indicadores que contemplam todas as normas são avaliados sem fazer menção à integração em si como, por exemplo, o indicador "comunicação adequada". 
O trabalho de Sampaio, Saraiva e Domingues (2012) analisa as abordagens e níveis de integração. Com base no estudo de caso feito em Portugal, eles estabeleceram 4 níveis de integração: 1 - integração de documentos; 2 - integração de ferramentas de gestão; 3 políticas e metas comuns; 4 - estrutura organizacional comum.

Para Beckmerhagen et al. (2003), a integração dos sistemas de gestão pode ocorrer em 3 graus: harmonização, cooperação e fusão. A harmonização e coordenação parcial dos documentos é o nível mais básico de integração. O nível mais avançado da integração é a fusão dos sistemas de gestão em um único sistema abrangente.

De acordo com o artigo de Domingues et al. (2012), os autores estão desenvolvendo uma ferramenta de avaliação de maturidade e eficiência focando em SGI. Porém, os resultados apresentados são parciais e o artigo não apresenta como será feita a avaliação de forma detalhada, apenas mostra que a mesma será feita com base em um questionário que se utilizará da escala Likert, tendo 30 questões ao todo, as quais englobarão a caracterização da empresa; percepção dos requisitos comuns; motivações, benefícios, obstáculos; caracterização específica da companhia considerando SGI; e avaliação da percepção entre a não integração e desempenho.

Por fim, o trabalho de Mežinska, Lapina e Mazais (2013) elabora uma ferramenta de autoavaliação com o foco na integração sob a perspectiva da sustentabilidade, considerando a integração uma forma de implementar o desenvolvimento sustentável no nível organizacional. A ferramenta elaborada foi dividida em três sessões: responsabilidades da alta administração e questões gerais de SGI; responsabilidades dos empregados; e processos e documentação. Para cada uma dessas sessões, os itens são classificados em não integrados, parcialmente e totalmente integrados. Essa ferramenta é indicada tanto para empresas que já possuem a integração como aquelas que ainda não possuem. Embora essa pesquisa não se utilize do conceito de modelo de maturidade, sua forma de abordagem se aproxima do conceito, pois realiza o detalhamento de cada um dos três níveis para cada item.

\subsection{Modelo de Maturidade}

As iniciativas relacionadas à gestão da qualidade e melhoria de processos influenciam no aumento de utilização de padrões, modelos e regulamentos que tem sido publicado. À medida que aumenta a utilização desses requisitos, mais as organizações se sentem confusas. Os modelos de maturidade surgem nesse cenário, auxiliando no processo de avaliação e de 
melhoria. O modelo pioneiro foi elaborado por Crosby e ficou conhecido como Crosby's Quality Management Maturity Grid - Aferidor de Maturidade da Gerência da Qualidade (MAIER; MOULTRIE; CLARKSON, 2012).

O conceito do Aferidor de Maturidade da Gerência da Qualidade foi publicado no livro "Quality is Free" de Crosby em 1979. No Brasil, o livro foi traduzido em 1986 recebendo o nome "Qualidade é Investimento". O modelo é dividido em 5 níveis de maturidade e conta com 6 categorias gerenciais, ou seja, 6 pontos que são avaliados. Os níveis de maturidade estabelecidos nesse modelo são: incerteza, despertar, esclarecimento, sabedoria e certeza. No estágio de incerteza, a gerência não considera a qualidade como um dos seus instrumentos positivos, sendo tudo muito confuso e descompromissado. Já no outro extremo, no estágio de certeza, a resolução de problemas pode vir a ser algo em extinção, pois a prevenção é tão boa que é muito difícil que problemas significativos ocorram. O objetivo do aferidor é acionar as pessoas e não apenas comunicar os resultados. A recomendação de Crosby quanto ao preenchimento do Aferidor é de que o mesmo seja respondido por 3 pessoas: gerente da qualidade, gerente geral da operação e por um membro do staff que não trabalhe no local (CROSBY, 1986).

Um dos mais conhecidos modelos, o CMM - Capability Maturity Model, foi inspirado no Aferidor de Maturidade de Crosby e muitos dos modelos que se basearam no CMM não possuem definição nítida do que vem a ser nível de maturidade (PAULK, 2008). O CMM foi elaborado através do Software Engineering Institute (SEI) - Carnegie Mellon, sendo que esse instituto elaborou vários outros modelos depois do CMM, entre eles o CMMI - Capability Maturity Model Integration (BRUIN et al., 2005). Na definição de Quintella e Rocha (2006), nível de maturidade é um estágio evolutivo bem definido em direção à melhoria de processo, sendo que cada nível serve de suporte para a melhoria contínua do processo.

São várias as definições para modelo de maturidade e a seguir estão quatro delas. Os modelos de maturidade são usados como ferramentas de melhoria de processo, descrevendo o processo em patamares de sofisticação, objetivando orientar o esforço de melhoria (CRISTOFARI JÚNIOR; PAULA; FOGLIATTO, 2010). A representação da maturidade através de número de estágios acumulativos facilita a visualização de onde a empresa está e o quanto falta para ela atingir as melhores práticas, sendo que os estágios mais baixos servem de suporte para atingir os requisitos dos estágios mais altos (MAIER; MOULTRIE; CLARKSON, 2012). Os modelos de maturidade auxiliam na melhoria do desempenho organizacional, ajudando a identificar os pontos fracos e fortes e contribuindo para o 
benchmarking (KHOSHGOFTAR; OSMAN, 2009). Modelo de maturidade é uma estrutura constituída de partes que definem maturidade em uma área específica (PMI, 2003).

Segundo Cuenca et al. (2013), todos os modelos de maturidade tem como características comuns a definição de áreas ou domínios-chave para serem avaliadas e o nível de maturidade para cada área ou domínio. Partindo desse ponto, os autores propuseram o que eles chamam de meta-modelo de maturidade, o qual pode ser resumido na Figura 1. Lembrando que a avaliação de maturidade representa a realidade de um momento, o qual pode ser alterado de acordo com o tempo. Para estes autores, os modelos de maturidades são importantes à medida que ajudam a entender a situação da organização, bem como contribuem para encontrar a forma mais adequada de se melhorar.

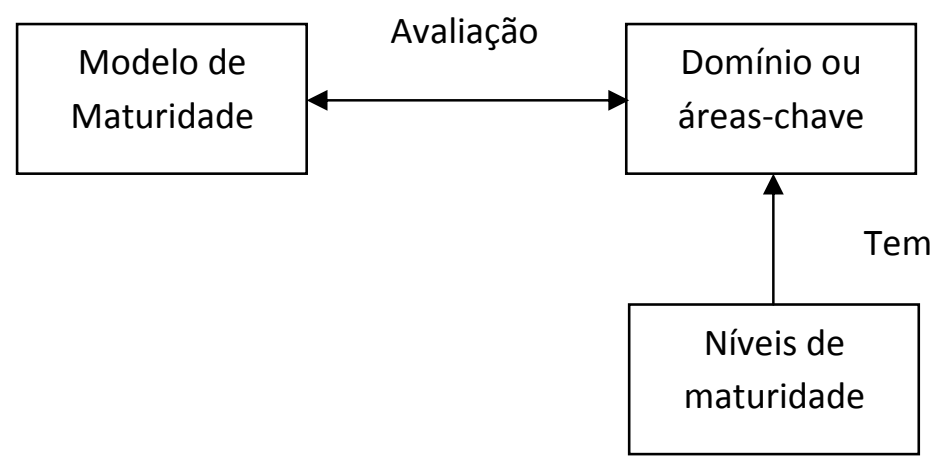

Figura 1 - Meta-Modelo de Maturidade

Há modelos de maturidade para várias áreas entre elas a gestão da qualidade, desenvolvimento de software, desenvolvimento de produtos, inovação, entre outros. Apesar de existir um grande número de modelos de maturidade, eles compartilham de vários aspectos comuns. Entre os componentes que podem ou não estar presentes nos modelos está: número de níveis (normalmente entre 3 a 6), um descritivo para cada nível (ex: inicial, gerenciável), um sumário das principais características do descritivo comentado anteriormente, um número de dimensões ou áreas de processos, um número de elementos ou atividades para cada área de processo, e a descrição de cada atividade que poderia representar cada nível de maturidade (FRASER; MOULTRIE; GREGORY, 2002). Em outro estudo, onde se realizou a análise de 16 modelos de maturidade, foi possível notar que, apesar de diferentes quanto as suas características, os modelos apresentam muitas semelhanças e isso ocorre devido ao fato de os modelos serem construídos com base em seus antecessores (KOHLEGGER; MAIER; THALMANN, 2009). 
De acordo com Khoshgoftar e Osman (2009), uma deficiência em termos de modelo de maturidade é o fato de não haver um padrão global de modelo de maturidade. Porém, isso ocorre por ser um conceito novo que precisa de mais esclarecimentos e considerações por parte das empresas e pesquisadores.

Os modelos podem ser classificados em três categorias: grades de maturidade; modelos de maturidade e capacidade; e mistos. As grades de maturidade contem texto descritivo para cada atividade de cada nível de maturidade e apresentam dificuldade moderada de aplicação. Os modelos de maturidade e capacidade são mais formais e complexos, e apesar de haver descrição de maturidade para cada nível, não há descrição individual para cada atividade e eles fixam práticas e objetivos que serão alcançados em cada área, em vez de simplesmente dizer o que deve ser feito. Os modelos mistos costumam ser mais simples de se aplicar e possuem características dos dois apresentados anteriormente, além de combinarem o uso de questionário com definições de maturidade (FRASER; MOULTRIE; GREGORY, 2002).

Outro ponto interessante é a distinção entre as grades de maturidade e a escala Likert. No caso do questionário híbrido baseado na escala Likert, apenas um nível é descrito, sendo geralmente o nível superior, enquanto nos demais são usados termos gerais como "discordo" ou "discordo totalmente". Com isso, é deixado ao entrevistado interpretar as gradações sem nenhuma outra orientação. As grades de maturidade auxiliam na resolução do problema de interpretação do questionário baseado na escala Likert, pois conta com uma riqueza de descrição dos níveis (FRASER; MOULTRIE; GREGORY, 2002).

Vale a pena ressaltar que o modelo de maturidade auxilia a empresa a diagnosticar os pontos onde não estão bem, mas é preciso mesclar com ferramentas que auxiliem no processo de priorização das ações e de implantação das mesmas como, por exemplo, a utilização da ferramenta 5W1H, Matriz de Priorização, etc. Saber o que deve ser melhorado é um passo extremamente importante, mas ele por si só não trás a melhoria necessária para se atingir um nível de maturidade mais elevada.

As subseções a seguir apresentam um breve descritivo de alguns modelos que serviram de referência para esse trabalho.

\subsubsection{CMMI}

O CMM (Capability Maturity Model) foi criado pelo SEI (Software Engineering Institute) ligado ao Carnegie Mellon University e concebido para desenvolvimento de software. 
Posteriormente foram criados uma série de CMMs para diferentes fins como Engenharia de Sistemas, Engenharia de Software, Aquisição de Software, e Desenvolvimento Integrado de Processo e Produto. Porém, o uso de múltiplos modelos pela mesma organização se tornou problemático e dessa demanda surgiu o CMMI (Capability Maturity Model Integration), o qual objetiva a melhoria de processo no desenvolvimento de produtos e serviços e visa uma maior integração dos CMMs. As versões anteriores do CMMI ficaram conhecidas como CMMI para Engenharia de Sistemas e Engenharia de Software (CMMI - SE/SW), sendo substituídas pela versão CMMI para Desenvolvimento (CMMI - DEV), a qual uniu informações das duas anteriores e buscou refletir a integração desses conhecimentos (CARNEGIE MELLON INSTITUTE, 2006).

O CMMI permite abordar melhoria e avaliação de processos através de duas representações: contínua e estágios. A representação contínua utiliza níveis de capacidade para representar a melhoria associada a uma área em particular, sendo que é a organização que escolhe essa área a ser melhorada. A representação por estágios utiliza níveis de maturidade, sendo que cada nível de maturidade contém um conjunto de áreas de processo pré-estabelecidos que orienta por qual caminho a melhoria deve ser feita na organização (CARNEGIE MELLON INSTITUTE, 2006).

O modelo CMMI-DEV é composto por 22 áreas de processos. Uma área de processo é um conjunto de práticas que quando implantadas satisfazem um conjunto de metas que são importantes para realizar melhorias significativas. Além das áreas de processos, o CMMI conta com metas genéricas e específicas, bem como com práticas genéricas e específicas, as quais auxiliam a implantação das melhorias (CARNEGIE MELLON INSTITUTE, 2006).

Os níveis de maturidade diferem com relação à representação. A Figura 2 compara as diferenças e similaridades entre eles (CARNEGIE MELLON INSTITUTE, 2006).

\begin{tabular}{ccc}
\hline Nível & $\begin{array}{c}\text { Representação Contínua } \\
\text { Níveis de Capacidade }\end{array}$ & $\begin{array}{c}\text { Representação por Estágios } \\
\text { Níveis de Maturidade }\end{array}$ \\
\hline Nível 0 & Incompleto & Não se aplica \\
Nível 1 & Executado & Inicial \\
Nível 2 & Gerenciado & Gerenciado \\
Nível 3 & Definido & Definido \\
Nível 4 & Gerenciado Quantitativamente & Gerenciado Quantitativamente \\
Nível 5 & Em otimização & Em otimização \\
\hline
\end{tabular}

Figura 2 - Comparação entre os Níveis de Capacidade e os Níveis de Maturidade Fonte: Carnegie Mellon Institute (2006) 


\subsubsection{Modelo Prado - MMGP}

O modelo Prado - MMGP (Modelo de Maturidade em Gerenciamento de Projetos) é um modelo de maturidade elaborado por um consultor chamado Darci Prado, por isso a origem do nome. Com base nesse modelo é feita uma pesquisa desde 2005 para avaliar o nível de maturidade das empresas com relação ao Gerenciamento de Projetos. O modelo Prado MMGP contempla 5 níveis e 6 dimensões, conforme demonstrado na Figura 3 (MATURITY BY PROJECT CATEGORY MODEL, 2013a).

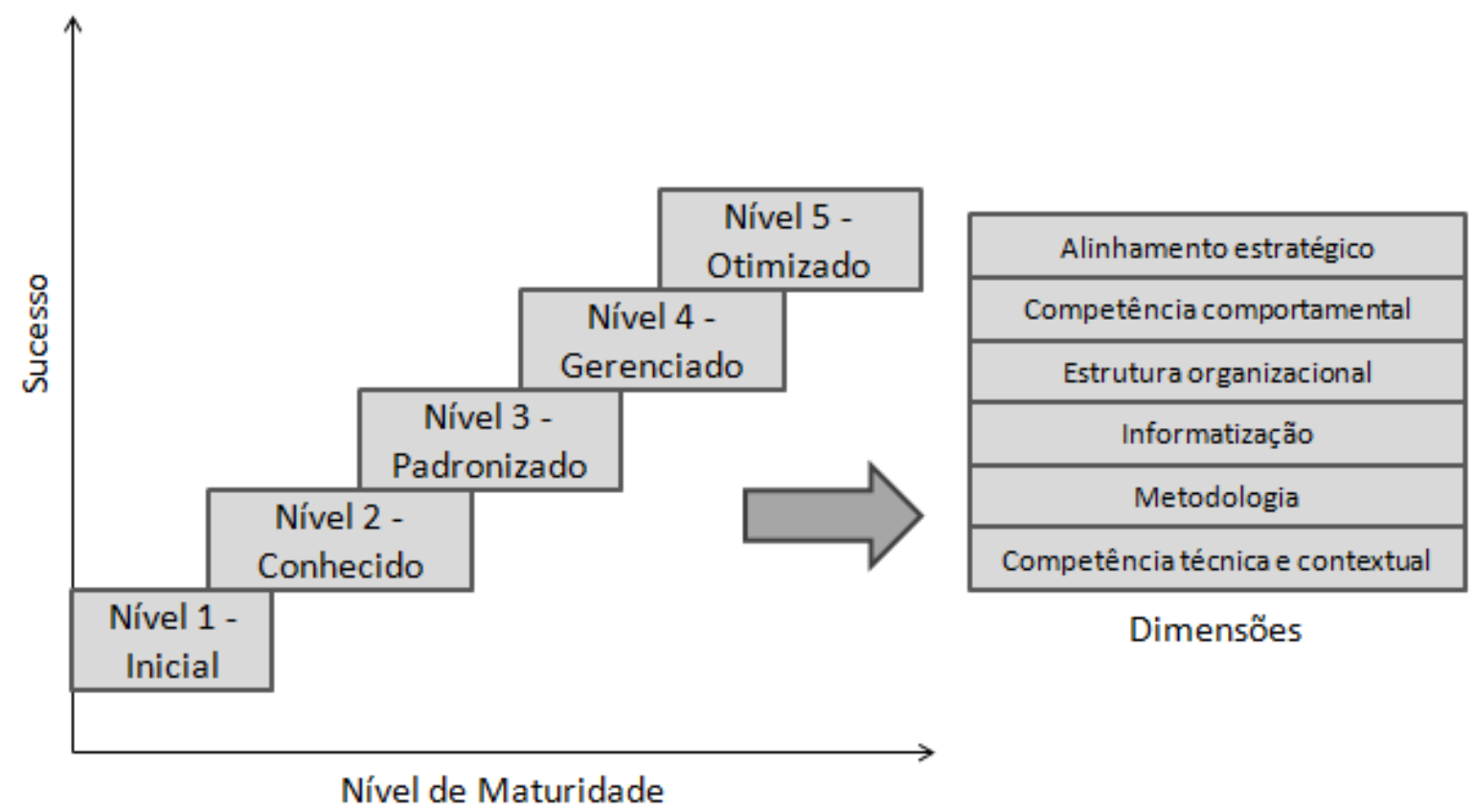

Figura 3 - Níveis e dimensões Fonte: Maturity by Project Category Model (2013a)

Esse modelo conta com um questionário que é utilizado para fornecer a informação de que nível se encontra a empresa em termos de maturidade em Gerenciamento de Projetos. Cada um dos níveis contem 10 questões de múltipla escolha (do nível 2 a 4 possuem 5 alternativas cada questão, e o nível 5 contem 2 alternativas cada questão). Após os participantes responderem o questionário, é fornecido um resultado do nível de maturidade. As descrições dos níveis de maturidade são muito semelhantes ao utilizado pelo CMMI (NETO, 2011).

O resultado final é apresentado conforme a Figura 4. Por exemplo, se a empresa apresenta uma pontuação média de 1,8 e um perfil conforme figura à esquerda, a empresa tem um nível de maturidade 1, ou seja, apresenta apenas algumas iniciativas isoladas e precisa de um grande programa de melhoria. Mas se a pontuação média é de 3,6 e possui um perfil de 
acordo com figura à direita, pode-se concluir que a empresa já se encontra com os níveis 2 e 3 consolidados, estando a caminho da evolução para o nível 4 (MATURITY BY PROJECT CATEGORY MODEL, 2013b).

\begin{tabular}{|c|c|c|c|c|c|}
\hline \multirow{2}{*}{ Nível } & \multicolumn{5}{|c|}{ Percentual de Aderência } \\
\hline & $\mathbf{2 0} \%$ & $\mathbf{4 0 \%}$ & $\mathbf{6 0 \%}$ & $\mathbf{8 0 \%}$ & $\mathbf{1 0 0 \%}$ \\
\hline 1 & & & & & \\
\hline 2 & & & & & \\
\hline 3 & & & & & \\
\hline 4 & & & & & \\
\hline
\end{tabular}

\begin{tabular}{|c|c|c|c|c|c|}
\hline \multirow{2}{*}{ Nível } & \multicolumn{5}{|c|}{ Percentual de Aderência } \\
\hline & $\mathbf{2 0 \%}$ & $\mathbf{4 0 \%}$ & $\mathbf{6 0 \%}$ & $\mathbf{8 0} \%$ & $\mathbf{1 0 0} \%$ \\
\hline 1 & & & & & \\
\hline 2 & & & & & \\
\hline 3 & & & & & \\
\hline 4 & & & & & \\
\hline
\end{tabular}

Figura 4 - O perfil de avaliação da maturidade Fonte: Maturity by Project Category Model (2013b)

\subsubsection{OPM3}

O OPM3 (Organizational Project Management Maturity Model) surgiu em 1998 com o objetivo de ajudar as organizações a transformarem as estratégias em resultados positivos. $\mathrm{O}$ propósito do OPM3 é auxiliar a organização a entender sua gestão de projetos, medir sua maturidade nesse aspecto e ajudar a melhorar seu nível de maturidade. Ele foi criado pelo PMI (Project Management Institute). O modelo é composto por 3 elementos: conhecimento (provê o conteúdo do padrão), avaliação (apresenta o método de comparação com o padrão) e melhoria (providencia o preparo para a melhoria) (PMI, 2003).

Esse modelo é multidimensional conforme mostra a Figura 5. No caso do OPM3, a base do modelo são os chamados domínios: projetos, programas e portfólios. Os programas consistem de múltiplos projetos, porém nem todos os projetos serão necessariamente parte de um programa. O portfólio é o conjunto de programas, projetos e todas saídas relacionado aos projetos dentro da organização. Uma vez que o domínio foi selecionado, o próximo passo é considerar o estágio da melhoria de processo, sendo que há uma progressão natural da maturidade, a qual começa pela Padronização, passa pela Medição, Controle e termina com a Melhoria Contínua (PMI, 2003). 


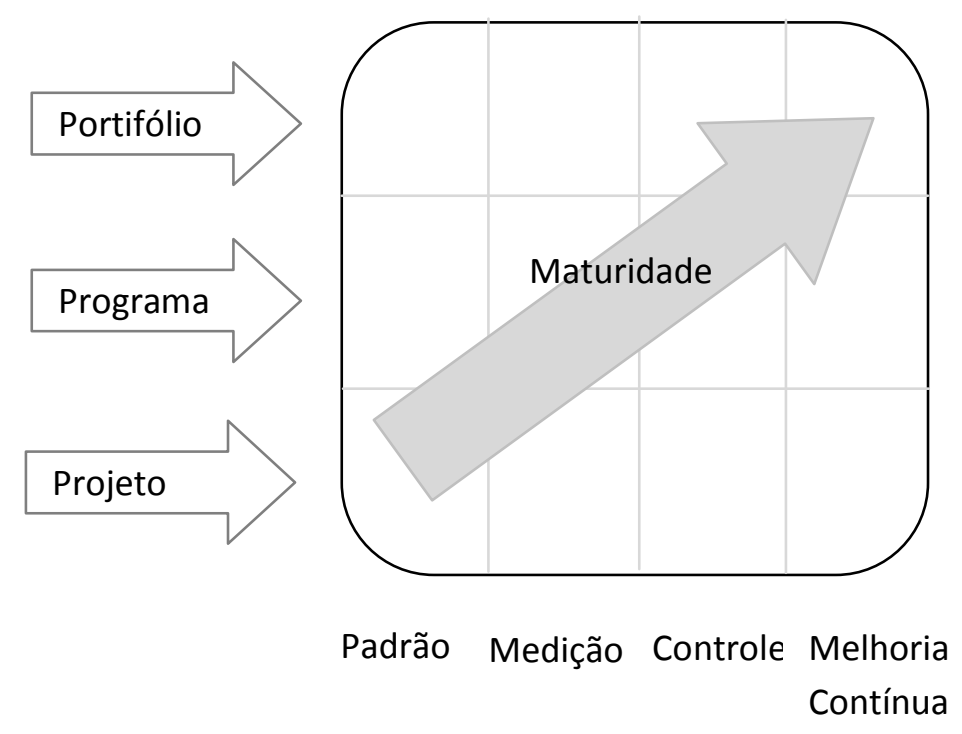

Figura 5 - Evolução da maturidade em gestão de projetos Fonte: PMI (2003)

\subsubsection{Modelo de Maturidade apresentado na ISO 9004:2010}

A ISO 9004:2010 apresenta um modelo de maturidade para avaliar o sistema de gestão voltado para a qualidade. Na norma, um modelo de maturidade formado por 5 níveis de maturidade é sugerido como uma forma de se fazer uma auto-avaliação. São avaliados os seguintes aspectos da norma: gestão para sucesso sustentado; estratégia e política; gestão de recursos; gestão de processos; monitoramento, medição, análise e análise crítica; e melhoria, inovação e aprendizagem. A ISO 9004 complementa a ISO 9001, fornecendo uma visão mais ampla da gestão da qualidade, pois trata das expectativas e necessidades de todas as partes interessadas, além de contribuir com a melhoria sistemática e contínua do desempenho da organização. A seguir é apresentado na Figura 6 como um dos itens é avaliado (ASSOCIAÇÃO BRASILEIRA DE NORMAS TÉCNICAS, 2010). 


\begin{tabular}{|l|l|l|l|l|l|}
\hline \multicolumn{1}{|c|}{$\begin{array}{l}\text { Elemento - } \\
\text { Chave }\end{array}$} & \multicolumn{1}{|c|}{ Nível 1 } & \multicolumn{1}{|c|}{ Nível 2 } & \multicolumn{1}{|c|}{ Nível 3 } & \multicolumn{1}{c|}{ Nível 4 } & \multicolumn{1}{c|}{ Nível 5 } \\
\hline $\begin{array}{l}\text { Comunicaçã } \\
\text { o da } \\
\text { estratégia e } \\
\text { política }\end{array}$ & $\begin{array}{l}\text { A comunicação } \\
\text { ocorre de uma } \\
\text { forma reativa }\end{array}$ & $\begin{array}{l}\text { Um processo } \\
\text { para } \\
\text { comunicação } \\
\text { externa e interna } \\
\text { é definido e } \\
\text { implementado }\end{array}$ & $\begin{array}{l}\text { Sistemas } \\
\text { eficazes para se } \\
\text { comunicar } \\
\text { mudanças em } \\
\text { estratégia e } \\
\text { planos às } \\
\text { pessoas } \\
\text { relevantes dentro } \\
\text { da organização } \\
\text { estão em uso }\end{array}$ & $\begin{array}{l}\text { Mudanças na } \\
\text { política são } \\
\text { comunicadas às } \\
\text { partes } \\
\text { interessadas } \\
\text { pertinentes, e } \\
\text { para todos os } \\
\text { níveis da } \\
\text { organização }\end{array}$ & $\begin{array}{l}\text { A eficácia dos } \\
\text { processos de } \\
\text { comunicação é } \\
\text { analisada crítica } \\
\text { e regularmente. } \\
\text { Há evidências de } \\
\text { que processos de } \\
\text { comunicação } \\
\text { atendem às } \\
\text { necessidades das } \\
\text { partes } \\
\text { interessadas }\end{array}$ \\
\hline
\end{tabular}

Figura 6 - Exemplo da avaliação do nível de maturidade em gestão da qualidade Fonte: Associação Brasileira de Normas Técnicas (2010)

\subsubsection{EcoM2}

O objetivo do EcoM2 (Ecodesign Maturity Model) é fornecer um modelo de maturidade que possa dar suporte às empresas no seu processo de implantação de práticas de ecodesign, fornecendo uma estrutura capaz de avaliar a situação atual, bem como auxiliá-la na visualização das oportunidades de melhorias, na seleção e priorização das práticas de ecodesign, e de sua implantação (PIGOSSO; ROZENFELD; MCALOONE, 2013).

A avaliação ocorre através de uma planilha como a da Figura 7, onde cada prática recebe um código, sendo descrito o mesmo logo a frente do seu número. Cada avaliador dá sua nota e depois é calculado o nível de capabilidade com base nas notas dadas pelos funcionários da própria empresa. 


\begin{tabular}{|c|c|c|}
\hline Código & Prática de Gestão de Ecodesign & $\begin{array}{c}\text { Nível de } \\
\text { Capacidade }\end{array}$ \\
\hline \multirow{7}{*}{$\begin{array}{l}\text { Xxxx } \\
\text { (código } \\
\text { da } \\
\text { prática) }\end{array}$} & $\begin{array}{l}\text { Questão relacionada à aplicação de prática de gestão } \\
\text { de ecodesign }\end{array}$ & $\mathrm{x}$ \\
\hline & \multicolumn{2}{|l|}{ Comentários: } \\
\hline & \multicolumn{2}{|c|}{$\begin{array}{l}\text { Comentários sobre a justificativa do porque a companhia é } \\
\text { classificada naquele nível e como a prática está sendo efetuada na } \\
\text { organização }\end{array}$} \\
\hline & E1: (comentários do entrevistado E1) & $\mathrm{y}$ \\
\hline & E2: (comentários do entrevistado E2) & $\mathrm{x}$ \\
\hline & E3: (comentários do entrevistado E3) & $\mathrm{x}$ \\
\hline & E4: (comentários do entrevistado E4) & $\mathrm{x}$ \\
\hline
\end{tabular}

Figura 7 - Exemplo de planilha para consolidação dos resultados Fonte: Pigosso (2012)

Depois de preenchida a planilha anterior, a mesma alimenta um gráfico como demonstra a Figura 8, o que torna de fácil visualização quais as práticas de gestão de ecodesign apresentam alto nível de capabilidade e quais precisariam ser melhoradas. Com base nisso é avaliado o que a empresa precisa fazer para melhorar.

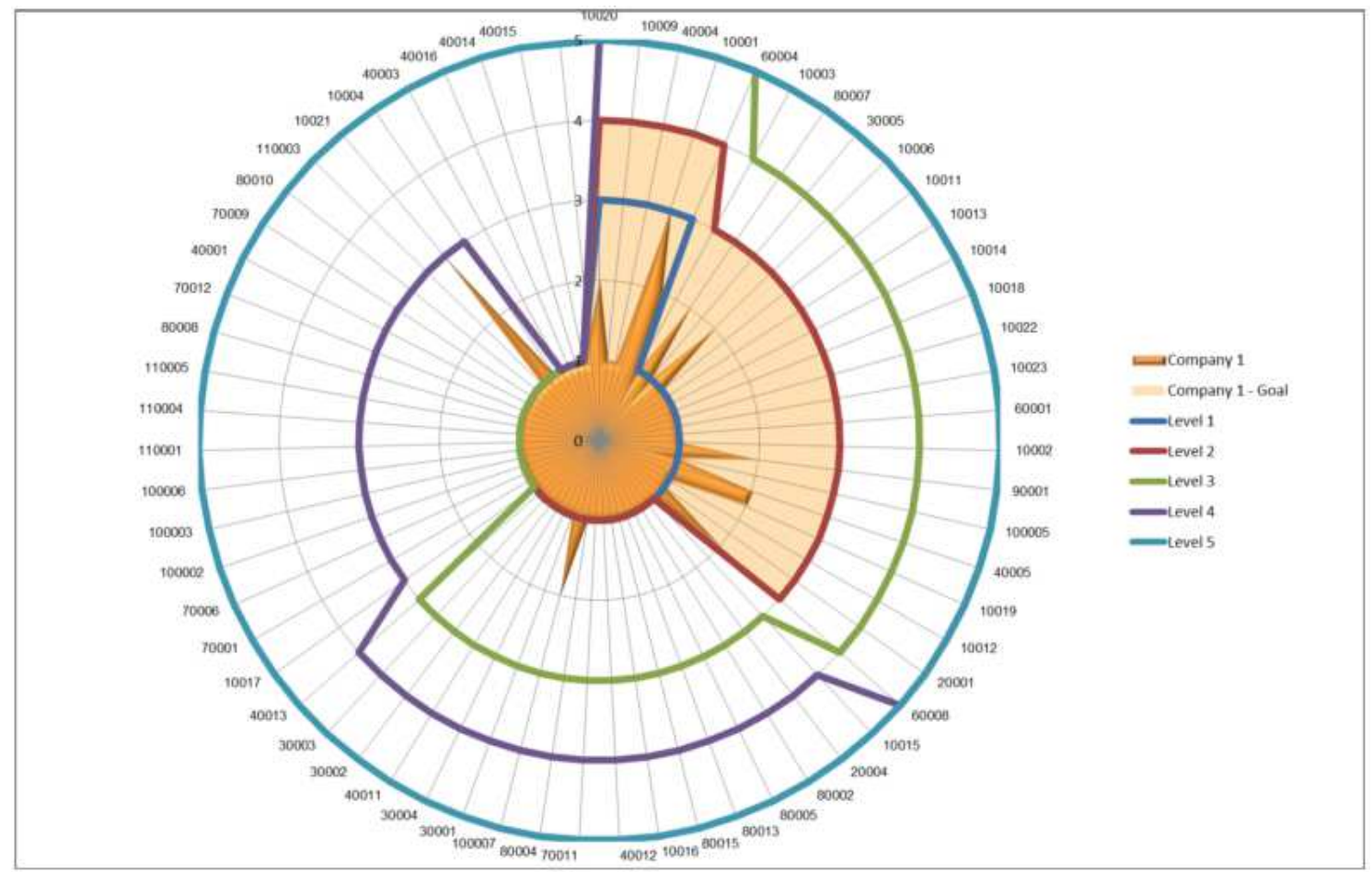

Figura 8 - Exemplo do resultado da avaliação usando o método EcoM2

Fonte: Pigosso (2012) 


\subsection{Considerações Gerais}

É cada vez mais comum se ouvir falar em normas, principalmente quando se leva em consideração um mundo globalizado onde é importante evitar divergências provocadas por características regionais.

Entre os vários tipos de normas que surgem, há as normas conhecidas como Sistemas de Gestão. Esses tipos de normas, não especificam requisitos para produtos, mas focam em requisitos relacionados a gestão em si de uma área específica. Os mais comuns sistemas de gestão são a ISO 9001 - Sistema de Gestão da Qualidade, ISO 14001 - Sistema de Gestão Ambiental e OHSAS 18001 - Sistema de Segurança e Saúde Ocupacional. No entanto, há muitos outros sistemas de gestão, alguns inclusive para setores específicos como o alimentício e de segurança da informação. Outro sistema de gestão existente é a NBR 16001 - Sistema de Gestão de Responsabilidade Social, sendo que esse é um sistema de gestão brasileiro pioneiro nessa área em termos mundiais.

Com o aumento do número de normas, torna-se cada vez mais importante integrá-las como forma de evitar redundâncias, duplicação de esforços e até mesmo inconsistências. Porém, o que se percebe pela revisão da literatura é que há diferentes formas de se integrá-las, que vão desde uma integração superficial até uma integração com visão mais ampla e estratégica.

Assim como se observa essa demanda por integração das normas, nota-se um aumento do número de modelos de maturidade, os quais são utilizados como forma de avaliação das condições atuais e contribuem para o processo de melhoria. Essa dissertação apresenta cinco modelos de maturidade, sendo eles o CMMI, Modelo Prado - MMGP, OPM3 e Modelo de Maturidade apresentado na norma ISO 9004 e EcoM2. O CMMI é um dos mais difundidos e ele serviu de base para o surgimento de muitos outros modelos de maturidade.

Apesar do surgimento de vários modelos de maturidade elaborados para diferentes segmentos, não se encontrou nenhum que abordasse a questão da integração de sistemas de gestão. $\mathrm{O}$ que se encontrou na literatura foram alguns trabalhos que tocavam na questão de níveis de integração, mas geralmente de forma mais superficial. 


\section{Método e passo-a-passo do desenvolvimento da pesquisa}

Segundo Karlsson (2009), a pesquisa tem como objetivo a criação e desenvolvimento do conhecimento, sendo que a contribuição para esse conhecimento é seu principal output. Em toda pesquisa, é importante estar atento a duas questões: validade e confiabilidade. A validade se refere à capacidade de se medir corretamente o que se propõe medir, enquanto a confiabilidade se refere à constância dos resultados (MARTINS; THEÓPHILO, 2009).

Cada vez mais as universidades estão sendo cobradas por atividades e pesquisas que envolvem o crescimento econômico e tenham aplicabilidade nos negócios, inclusive os financiamentos de pesquisa agora incluem uma avaliação em termos de comercialização (KARLSSON, 2009). No caso desta pesquisa, busca-se trazer essa contribuição tanto para as organizações que se utilizam dessas normas como para a área acadêmica. No entanto, conforme Karlsson (2009) ressalta, não são todas as perguntas de pesquisa que podem ser respondidas pelos métodos de pesquisa existentes. Por exemplo, ao se tentar descobrir uma prática comum em uma indústria, o método de pesquisa-ação pode não contribuir com o objetivo da pesquisa, assim como um survey pode ser muito superficial, não conseguindo captar as relações causais.

No caso da presente pesquisa, optou-se por realizar uma revisão exploratória seguida por uma Revisão Bibliográfica Sistemática (RBS) sobre SGI. Depois, fez-se uma revisão exploratória sobre Modelo de Maturidade, seguido da criação da ferramenta para avaliar a maturidade do SGI tendo como base as principais normas utilizadas e integradas pelas empresas, assim como os Modelos de Maturidades encontrados. Após a elaboração da ferramenta, a mesma foi avaliada por especialistas acadêmicos e profissionais da indústria que trabalham diretamente nessa área em duas empresas diferentes, sendo uma do ramo manufatureiro e outra de prestação de serviços. Essas avaliações foram feitas com o intuito de verificar possíveis correções, resultando na versão final da ferramenta. A Figura 9 apresenta um resumo do método utilizado. 


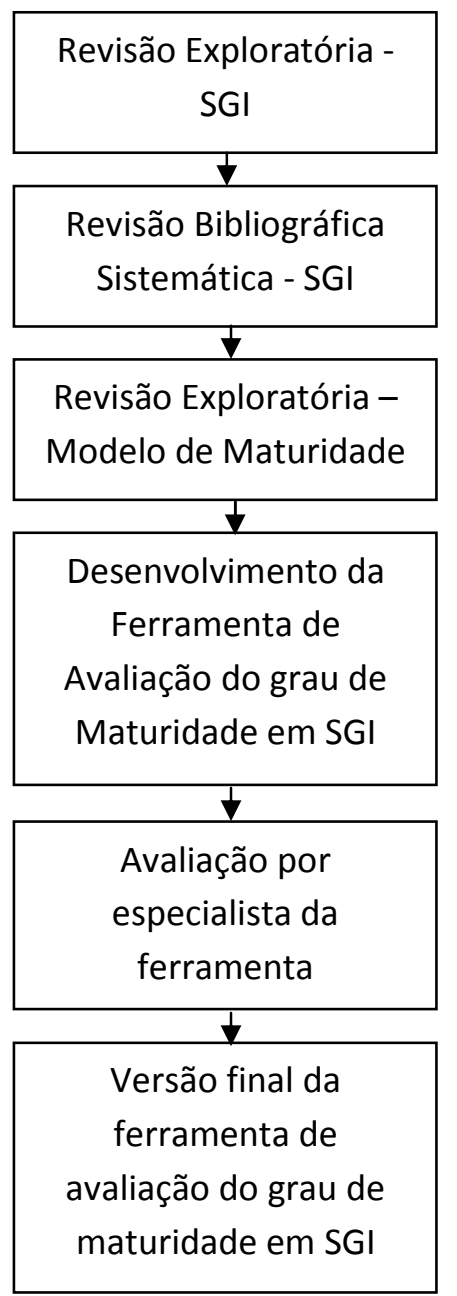

Figura 9 - Resumo do método utilizado na dissertação

\subsection{Revisão bibliográfica}

Primeiramente realizou-se uma busca em bases nacionais e internacionais sobre Sistema de Gestão Integrado (SGI), também chamada de pesquisa Exploratória, tendo sido encontrados nessa busca 21 artigos e 1 dissertação de mestrado que serviram como ponto inicial para todo o trabalho.

A etapa seguinte consistiu de realizar uma Revisão Bibliográfica Sistemática (RBS) sobre SGI. De acordo com Conforto, Amaral e Silva (2011), a RBS contribui no aumento do rigor e de melhores níveis de confiabilidade da revisão bibliográfica. Essa metodologia é muito difundida nas áreas de medicina, psicologia e ciências sociais. A proposta dos autores foi adequar a RBS para a área de gestão de operações e por essa razão ela foi selecionada, pois se adequa melhor à área de estudo desse trabalho. 
Através de leituras de artigos relacionados aos temas, construiu-se a string que foi usada nas bases de dados da Web of Science e Scopus. A string é uma junção de termos que são utilizados para promover buscas padronizadas em diferentes bases de dados. Levaram-se em consideração essas duas bases por ser consideradas as mais amplas na área. A seguir é possível se deparar com a string utilizada, sendo que para ambas as bases a pesquisa se limitou a buscas das palavras no título, resumo e palavras - chave.

\section{String:}

(("ISO" OR "OHSAS") AND ("integrated management system" OR "integrated management systems" OR (("standardized management system" OR "standardized management systems") AND (integrat*)) OR (("normalized management system" OR "normalized management systems") AND (integrat*))))

Após utilizar a string nas bases Web of Science e Scopus, encontraram-se 173 resultados, porém, 43 deles estavam duplicados, ou seja, encontrava-se em ambas as bases. O número total de artigos a ser analisado após retirar as duplicações foi de 130.

Os 130 artigos passaram por um primeiro filtro conforme indicado na literatura por Conforto, Amaral e Silva (2011), onde é feita uma leitura do título, resumo e palavras-chaves. Dos 130 artigos, conforme apresentado na Tabela 7, 46 deles (35\%) demonstraram estar coerentes com o propósito desta dissertação, 34 (26\%) não estavam aderentes ao propósito do trabalho e 50 (38\%) não tiveram seu texto completo encontrado, sendo que pela leitura feita do seu resumo, deu-se para perceber que os artigos não seriam relevantes para a temática da dissertação, embora abordassem a questão da integração. Apenas 1 dos 50 artigos não encontrados constatou-se que faria sentido ser obtido, o que foi feito junto ao autor.

\begin{tabular}{|c|c|}
\hline \multicolumn{2}{|c|}{ Tabela $7-$ Resultado do $1^{\circ}$ filtro em $\%$} \\
\hline $38 \%$ & Não encontrado \\
$35 \%$ & Selecionados \\
$26 \%$ & Não selecionados \\
\hline $100 \%$ & TOTAL \\
\hline
\end{tabular}

O $2^{\circ}$ filtro consistiu na leitura da introdução e conclusão conforme detalha a Tabela 8 , sendo que 4 artigos foram reprovados nessa etapa, passando apenas 42 artigos para a etapa final que foi chamada de $3^{\circ}$ filtro. 
Tabela 8 - Resultado do $2^{\circ}$ filtro em $\%$

\begin{tabular}{|c|c|}
\hline $91 \%$ & Selecionados \\
$9 \%$ & Não selecionados \\
\hline $100 \%$ & TOTAL \\
\hline
\end{tabular}

No $3^{\circ}$ filtro, o texto todo foi lido e apenas 1 artigo foi excluído. A seguir, é apresentado o Gráfico 9 que mostra a quantidade de artigos que passou por cada etapa.

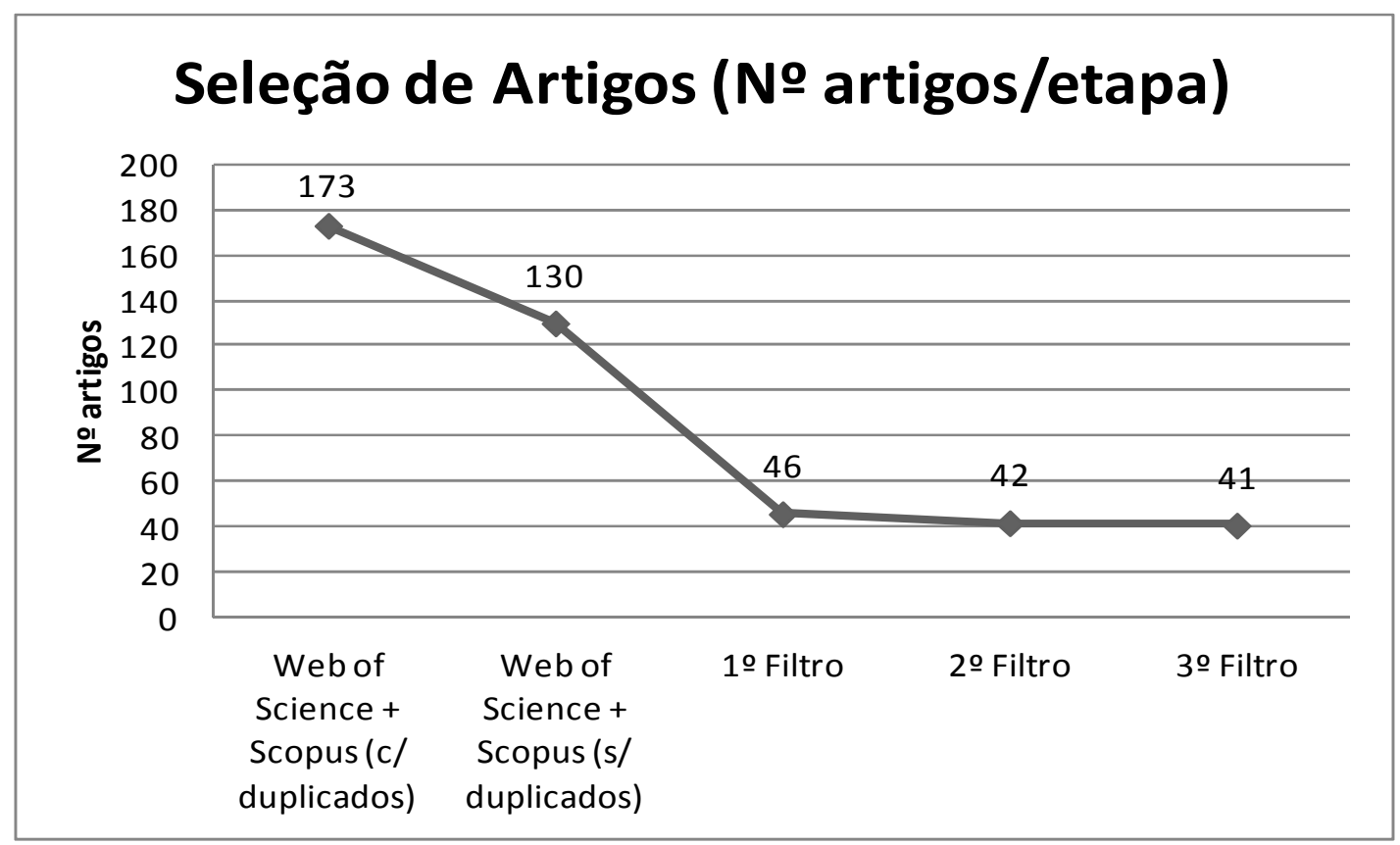

Gráfico 9 - Número de artigos por etapa da seleção

É importante salientar que dos 41 artigos resultantes do $3^{\circ}$ filtro, 8 deles já haviam sido encontrados na pesquisa Exploratória. No Gráfico 10, estão a quantidade de artigos encontrados em cada uma das etapas de busca:

- Exploratória (E): também conhecida como busca inicial. Somente nessa etapa foram encontrados 22 artigos, no entanto, 8 deles também estavam na busca sistemática. Portanto, se não fosse a busca exploratória pode-se concluir que 14 artigos não teriam sido considerados nesse trabalho.

- Sistemática (S): busca feita com base na RBS (Revisão Bibliográfica Sistemática). Nessa etapa foram encontrados 41 artigos, porém 8 deles também haviam sido levantados na pesquisa exploratória.

- Exploratória/Sistemática (E/S): artigos encontrados tanto pela busca Exploratória como também pela Sistemática. Optou-se por considerar os 8 artigos encontrados nas duas etapas de 
busca de forma separada para evitar duplicações no momento de contar o número de artigos total.

- Posterior (P): pesquisa feita após a RBS com base nos artigos lidos anteriormente (referências bibliográficas), bem como nos alertas cadastrados no Scopus e Web of Science.

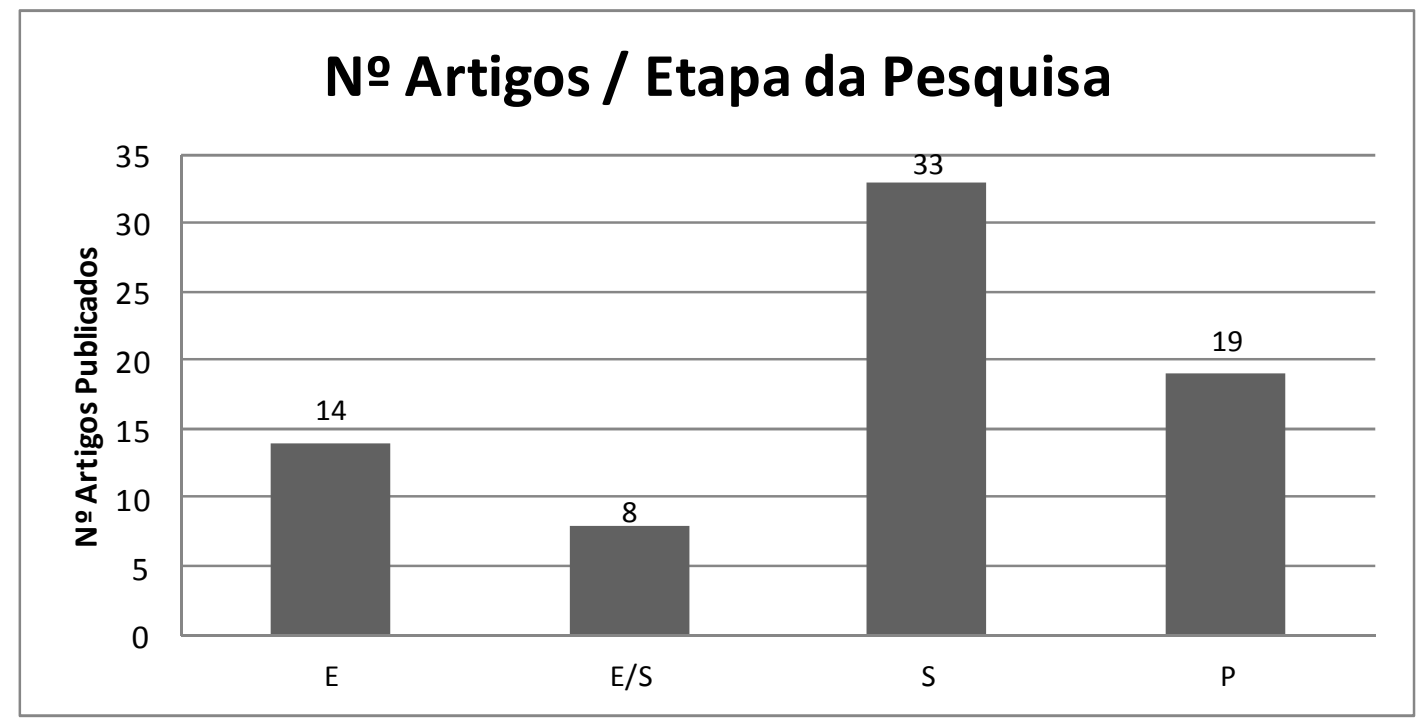

Gráfico 10 - Número de artigos por etapa da pesquisa

A seguir se encontra um resumo do processo utilizado para a revisão bibliográfica sobre SGI conforme é possível verificar Figura 10. 


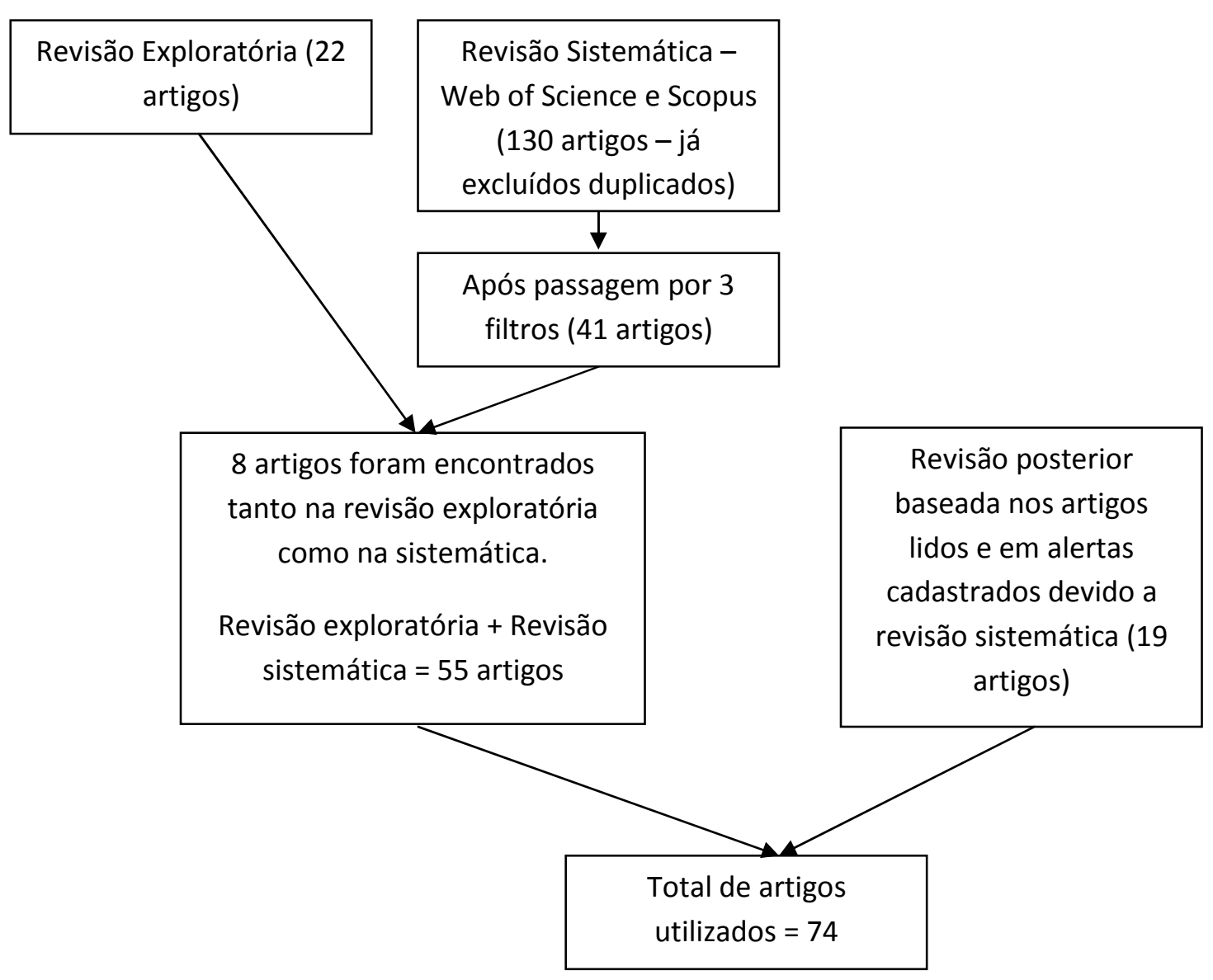

Figura 10 - Resumo da RBS em SGI

Na Figura 17 que se encontra no Apêndice A é possível encontrar um resumo dos principais pontos abordados por cada um dos 74 artigos encontrados sobre SGI tanto na revisão exploratória, como na sistemática e na posterior.

Depois de feita a revisão bibliográfica sobre SGI e notado uma lacuna quanto a existência de modelos de maturidade voltados para esse tema, foi realizada uma revisão bibliográfica sobre modelos de maturidade. A revisão consistiu inicialmente na leitura de uma tese de doutorado sobre modelos de maturidade em ecodesign de Pigosso (2012), bem como da leitura de um livro sobre CMMI intitulado "CMMI (Capability Maturity Model Integration): Guidelines for Process Integration and Product Improvement" (CHRISSIS; KONRAD; SHRUM, 2003). Além disso, foram realizadas buscas de artigos sobre modelos de maturidade em bases nacionais e internacionais, entrou-se em contato com pesquisadores que também estavam pesquisando sobre modelos de maturidade e para finalizar foram pesquisadas apostilas diretamente no site do SEI (Software Engineering Institute). 


\subsection{Desenvolvimento da ferramenta}

De acordo com Miguel et al. (2010), a utilização de modelos auxilia a compreensão do ambiente empresarial, contribuindo na identificação dos problemas, na formulação de estratégias, bem como nos processos de decisão. Resumindo, um modelo nada mais é do que a representação de uma situação ou realidade, sendo que essa representação deve contar com um detalhamento suficiente para representar o sistema real e ao mesmo tempo deve ser simplificado de modo a ser tratável por métodos de análise e resolução conhecidos. Um exemplo de modelo é o desenho de uma criança representando uma figura humana. A criança consegue capturar o essencial de uma pessoa como os olhos, boca, contorno do corpo, etc. Com base na definição apresentada, busca-se nessa dissertação, através do conceito de modelo, apresentar uma ferramenta que auxilie na representação da realidade através de diferentes níveis de maturidade de forma a auxiliar no processo de melhoria e tomada de decisão. Para se chegar a tal ferramenta, tomou-se como base o modelo de Buin et al. (2005) que possui as seguintes etapas demonstradas na Figura 11 e detalhadas a seguir.

De acordo com Bruin et al. (2005), deve-se primeiro levantar qual é o propósito do modelo, podendo ser de cunho descritivo, prescritivo ou comparativo. Quando se tem um propósito descritivo, foca-se apenas em relatar o momento atual. No caso prescritivo, a preocupação é com o desempenho e a melhoria. Enquanto que o comparativo tem sua atenção voltada para o benchmarking. Nessa pesquisa, a ferramenta tem como propósito descrever a situação atual, o qual irá auxiliar a empresa com base na avaliação da situação atual a busca por melhorias. Independente do propósito, o autor argumenta que as fases de construção do modelo são as mesmas e que seguir sua ordem é muito importante.

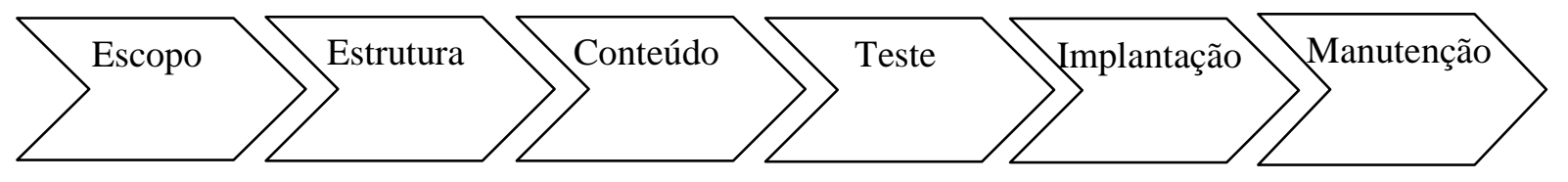

Figura 11 - Fases de desenvolvimento do modelo Fonte: Bruin et al. (2005)

A primeira fase consiste em estabelecer o escopo do modelo, ao qual irá influenciar as demais fases. Essa etapa define se o modelo terá foco em uma área específica ou geral. Um exemplo de modelo geral é o TQM (Total Quality Management), enquanto que um modelo específico é o CMM que é aplicado para o processo de desenvolvimento de software. Outro ponto a ser abordado nessa fase é quanto aos stakeholders, os quais podem vir de universidades, indústrias, ONG's e governo, podendo ajudar no desenvolvimento do modelo 
(BRUIN et al., 2005). Esta dissertação tem foco específico em SGI e os stakeholders são as indústrias, pois a ferramenta foi elaborada para ser aplicado em organizações por especialistas que trabalham nessa área, de forma a se avaliar se a mesma está adequada.

A segunda fase determina a estrutura do modelo, a qual servirá de base para o desenvolvimento e aplicação. Nessa fase serão incorporadas as necessidades do público alvo, refletidas em questões como "porque irão aplicar o modelo?; como o modelo poderá ser aplicado em diferentes estruturas organizacionais?; e o que precisa ser envolvido em sua aplicação?”. Para se atender as necessidades do público, é preciso haver o equilíbrio entre a realidade muitas vezes complexa e a simplicidade do modelo. Um princípio comum a ser estabelecido nessa fase é a representação da maturidade através de estágios acumulativos (BRUIN et al., 2005). A ferramenta proposta na dissertação visa ser de fácil aplicação pelos próprios especialistas que trabalham na empresa diretamente com sistemas de gestão e o resultado que sairá da aplicação do instrumento será útil para que a empresa faça uma autoavaliação de sua situação e com base nisso proponha melhorias para se atingir um nível de maturidade maior. $\mathrm{O}$ instrumento foi elaborado de forma a servir para qualquer tipo de organização.

Ainda de acordo com a segunda fase, tomou-se como base para elaboração da ferramenta quatro normas, sendo elas a ISO 9001, ISO 14001, OHSAS 18001 e NBR 16001. Optou-se pela escolha dessas normas uma vez que são amplamente conhecidas, principalmente quando se fala das três primeiras citadas, bem como pelo fato de as quatro normas representarem bem a questão da sustentabilidade, o qual foi um dos motivadores deste trabalho. Uma dúvida que pode surgir é quanto a escolha da norma NBR 16001 ao invés da SA 8000 - Social Accountability ou da ISO 26000 - Diretrizes para Responsabilidade Social. Isso se deu pelo fato de a NBR 16001 ser a única norma certificável de sistema de gestão de responsabilidade social. A SA 8000 foca nos direitos dos trabalhadores, nas condições no local de trabalho, porém a parte de sistema de gestão é tratado de forma superficial e não especificam a questão das auditorias, dos procedimentos e controle de documentos. Já a ISO 26000 é uma norma não certificável e que tem como foco as diretrizes de responsabilidade social e não o sistema de gestão em si. Devido a isso, optou-se pela escolha da NBR 16001, que apesar de possuir abrangência nacional apenas, é a primeira norma certificável de sistema de gestão em responsabilidade social. Com base na estrutura destas normas, foi dividido o instrumento em quatro grupos, sendo eles política, planejamento, implementação/execução e verificação/ação.

A terceira fase consiste em definir o conteúdo do modelo, sendo necessário identificar o que precisa ser medido na avaliação de maturidade e como será medido. Também é preciso 
estabelecer os componentes (BRUIN et al., 2005). Nas áreas do conhecimento bem desenvolvidas, os componentes podem ser descobertos através de uma revisão da literatura, sendo que nessa dissertação os componentes serão os requisitos das normas e os itens das normas.

Outro ponto importante na terceira fase é o número de questões, sendo que poucas perguntas podem prejudicar a qualidade do instrumento e um número muito grande pode dificultar a participação das pessoas pelo fator tempo. Porém, se o modelo for voltado para ser respondido por especialistas, um número maior de questões é aceitável. Mas se o foco for a resposta de várias pessoas dentro da organização de diferentes setores, será importante que o número de perguntas não seja tão alto. No caso dessa dissertação, a intenção é que a mesma seja respondida apenas por especialistas, no entanto, optou-se por não realizar um instrumento muito extenso para que houvesse maior interesse em mais de uma pessoa responder o mesmo, não ocupando muito do seu tempo.

A Tabela 9 apresenta a relação entre os itens das normas abordados por cada questão, ou seja, as questões de 1 à 4 referentes à política foram elaboradas com base nos itens 5.3 da ISO 9001, 4.2 da ISO 14001, 3.3 da OHSAS 18001 e 3.2 da NBR 16001. As questões foram divididas conforme a separação feita na segunda fase, onde foram considerados quatro grupos.

Tabela 9 - Relação entre as questões da ferramenta e os itens das normas

\begin{tabular}{|c|c|c|c|c|c|}
\hline & Questões N & ISO9001 & ISO14001 & OHSAS18801 & NBR16001 \\
\hline Política & 1 à 4 & 5.3 & 4.2 & 3.3 & 3.2 \\
\hline Planejamento & 5 à 7 & 5.4 & 4.3 & 3.5 & 3.3 \\
\hline Planejamento & 8 & 4.2 .2 & A.4.4 & 3.6 .5 & 3.5 .2 \\
\hline Planejamento & 9 e 10 & 4.2 & $4.4 .4 / 4.4 .5$ & $3.6 .5 / 3.6 .6$ & 3.5 \\
\hline Implementação/Execução & 11 & 7.1 & 4.4 .6 & 3.6 .7 & 3.4 .5 \\
\hline Implementação/Execução & 12 e 13 & 5.5 .1 & 4.4 .1 & 3.6 .1 & 3.3 .7 \\
\hline Implementação/Execução & 14 & 6 & 4.4 .1 & 3.6 .1 & 3.3 .7 \\
\hline Implementação/Execução & 15 & 6.2 .2 & 4.2 .2 & 3.6 .2 & 3.4 .1 \\
\hline Implementação/Execução & 16 & 5.5 .3 & 4.4 .3 & 3.6 .4 & 3.4 .3 \\
\hline Implementação/Execução & 17 & 8.2 & 4.5 .1 & 3.7 .1 & 3.6 .1 \\
\hline Verificação/Ação & 18 e 19 & 8.2 & 4.5 & 3.7 & 3.6 \\
\hline Verificação/Ação & 20 & 8.3 & 4.5 .3 & 3.7 .3 .2 & 3.6 .3 \\
\hline Verificação/Ação & 21 & 5.6 & 4.6 & 3.8 & \\
\hline
\end{tabular}


A quarta fase é a de se testar o modelo. Nessa etapa será solicitado que algumas pessoas utilizem o modelo e dêem sua sugestão. Por exemplo, o BPMM (Business Process Management Maturity) foi testado através da aplicação de um estudo de caso, incorporando pesquisas e entrevistas, conduzidas em duas organizações diferentes. É importante saber se a estrutura está adequada, se é fácil de responder, se o tempo para a resposta está adequado e se as questões estão adequadas ao propósito da pesquisa (BRUIN et al., 2005).

Nesta dissertação, esta etapa foi dividida em duas fases. Primeiro, houve a avaliação por especialistas acadêmicos realizada antes e no exame de qualificação. Ao todo, foram realizadas quatro avaliações, sendo três de membros da banca e uma de membro externo à banca. A outra avaliação foi feita por dois profissionais da indústria. Como critério de seleção para as empresas estavam o fato de terem ao menos dois sistemas de gestão integrados, além da questão de disponibilidade e proximidade da universidade. Primeiramente foi feito um contato por e-mail para que se pudesse verificar a disponibilidade na participação da pesquisa. Foram contactadas quatro empresas e duas delas deram retorno positivo. Após o aceite, foi enviado via e-mail uma carta convite para formalizar o contato. $\mathrm{O}$ modelo de carta utilizado se encontra no Apêndice B. No dia marcado com a empresa foi entregue um protocolo para o entrevistado para que pudesse passar uma visão geral do objetivo da mesma, sendo que o modelo de protocolo utilizado está no Apêndice C. Uma cópia da ferramenta proposta foi entregue ao entrevistado e deixou-se bem claro que o intuito da entrevista não era a avaliação do nível de maturidade da organização em si, mas a avaliação da aplicabilidade e coerência do instrumento, portanto a cópia entregue para o entrevistado não necessitava ser devolvida e as sugestões dadas por eles foram anotadas em uma folha separada pela própria pesquisadora. A duração média desta etapa nas duas empresas foi de 2 horas e meia, sendo realizada apenas uma visita.

É importante ressaltar que as visitas às empresas não tiveram caráter de estudo de caso, uma vez que o foco não foi verificar como a empresa agia, mas sim a análise por parte dos especialistas quanto ao instrumento proposto. A versão apresentada nas empresas já havia sido revisada pelos especialistas acadêmicos. Com base nas sugestões dadas pelos entrevistados, foi proposta uma versão final do instrumento. As maiores sugestões foram feitas pelos especialistas acadêmicos, os quais propuseram alterações principalmente quanto as descrições dos níveis. As sugestões feitas pelos profissionais da indústria consistiram mais na forma de escrita e não no conteúdo em si, uma vez que este último foi considerado pertinente por ambos os entrevistados, não necessitando de reajustes. Ambos os entrevistados eram os responsáveis pelo sistema de gestão integrado nas suas empresas e possuíam muito 
tempo de experiência na função. A empresa prestadora de serviços conta com a integração da ISO 9001 e ISO 14001, sendo que a integração foi feita após um tempo de implantadas ambas as normas. A empresa manufatureira conta com a ISO 9001, ISO 14001 e ISO TS 16949, sendo que a sua integração foi ocorrendo à medida que uma nova norma foi adotada. A versão final da ferramenta de avaliação de maturidade em SGI é apresentada no Capítulo 4.

A quinta fase consiste em tornar o modelo disponível para uso e implantá-lo, sendo que a sexta fase é a de manter o modelo (BRUIN et al., 2005). A disponibilização será feita através da publicação de artigos e da própria dissertação em si. A manutenção dependerá de cada organização, sendo que o aconselhável é que elas realizem periodicamente o instrumento para verificar os pontos que evoluíram e aqueles que ainda requerem melhorias. Além do mais, é importante que a empresa estabeleça qual o formato que ela utilizará para que os participantes preencham o modelo, se vão querer o formato em papel, via e-mail ou outro que julgar mais adequado.

De acordo com a tipologia estabelecida por Fraser, Moultrie e Gregory (2002), foi-se escolhido o modelo de maturidade tipo grade para servir de inspiração na elaboração da ferramenta uma vez que este é de mais fácil utilização do que os modelos de maturidade e capacidade, além de se evitarem possíveis dúvidas quanto à gradação como pode ocorrer com os modelos híbridos baseados na escala Likert. A grande diferença entre os trabalhos existentes que abordavam a questão dos níveis de intregração para o presente trabalho é que no caso dos níveis, eles apresentavam geralmente gradações do tipo "não integrado", "parcialmente integrado" e "totalmente integrado" para cada item que estabelecem, normalmente não definindo como seria em detalhe nem mesmo um dos extremos. Por exemplo, qual seria a descrição para o nível "totalmente integrado" da auditoria externa? Este tipo de detalhamento não é explicitado nos trabalhos de nível de maturidade. Enquanto que no caso dos modelos de maturidade há esse detalhamento dos níveis. Mais especificamente nas grades de maturidade, esse detalhamento é feito para cada nível. 


\section{Proposta da Ferramenta de Avaliação do Grau de Maturidade em SGI}

Com base na revisão da literatura sobre Modelo de Maturidade e na estrutura de normas ISO 9001, ISO 14001, OHSAS 18001 e NBR 16001 foi elaborada a ferramenta para avaliar o nível de integração do SGI. Os principais modelos de maturidade que influenciaram a elaboração deste trabalho foram o CMMI e o modelo apresentado na ISO 9004. No item 4.1 encontra-se uma breve descrição dos níveis de maturidade, bem como a apresentação da ferramente inicial de maturidade para SGI. No item 4.2 é apresentado a versão final da ferramenta, bem como as orientações para seu uso.

A ferramenta foi desenvolvida seguindo os passos proposto por Bruin (2005). Resumidamente, a ferramenta tem como propósito descrever a situação atual da organização com relação ao nível de integração dos seus sistemas de gestão. Os stakeholders que irão influenciar e auxiliar o desenvolvimento da ferramenta serão as indústrias. Outro ponto é quanto à aplicação, sendo que a ferramenta proposta visa ser de fácil aplicação pelos próprios especialistas que trabalham na organização com sistemas de gestão.

\subsection{Versão inicial da Ferramenta de Avaliação do Grau de Maturidade em SGI}

A ferramenta de avaliação do grau de maturidade em SGI conta com dois eixos. Na primeira linha são apresentados os níveis de maturidade elaborados com base no CMMI. A Figura 12 apresenta uma comparação entre os níveis apresentados no CMMI e os itens elaborados para a ferramenta. Na primeira coluna foram colocadas as atividades e elementoschave importantes para a integração dos sistemas de gestão. Para a escolha das atividades e elementos-chave foram usados como base as normas ISO 9001, ISO 14001, OHSAS 18001 e

NBR 16001. É válido ressaltar que não foram levados em conta aspectos específicos de tais normas para que a ferramenta pudesse ser ampla e englobar outras normas que não apenas essas. A interseção desses elementos resultam no nível de integração que vai de 1 (baixo nível de integração) à 5 (alto nível de integração). 


\begin{tabular}{|c|c|c|c|}
\hline \multicolumn{2}{|r|}{$\begin{array}{l}\text { CMMI } \\
\text { Fonte: Carnegie Mellon Institute (2006) }\end{array}$} & \multicolumn{2}{|r|}{$\begin{array}{c}\text { Ferramenta de Avaliação do Grau de } \\
\text { Maturidade - SGI } \\
\text { Fonte: própria autora }\end{array}$} \\
\hline Inicial & $\begin{array}{l}\text { Os processos são geralmente caóticos. O } \\
\text { sucesso fica a cargo da competência das } \\
\text { pessoas e não propriamente do uso de } \\
\text { processos comprovados. A organização } \\
\text { produz produtos e serviços que funcionam, } \\
\text { mas normalmente o orçamento é } \\
\text { extrapolado e os prazos não são cumpridos, } \\
\text { sendo difícil repetir os próprios sucessos. }\end{array}$ & Nível 1 & $\begin{array}{l}\text { A organização não consegue trabalhar suas } \\
\text { normas de modo integrado. Quando ocorre } \\
\text { alguma iniciativa de integração, nota-se que } \\
\text { a mesma não é sólida e ao menor grau de } \\
\text { dificuldade a integração pode ser desfeita. } \\
\text { Os benefícios não são aparentes. }\end{array}$ \\
\hline Gerenciado & $\begin{array}{l}\text { Os processos são planejados e executados } \\
\text { conforme uma política. As pessoas que } \\
\text { trabalham são experientes e tudo é } \\
\text { controlado, monitorado e revisado. A } \\
\text { disciplina colabora para que as práticas } \\
\text { existentes se mantenham até mesmo durante } \\
\text { períodos turbulentos. }\end{array}$ & Nível 2 & $\begin{array}{l}\text { É possível notar uma efetiva integração em } \\
\text { alguns pontos das normas e mesmo as partes } \\
\text { não integradas estão alinhadas entre elas, } \\
\text { evitando que uma norma contradiga a outra. }\end{array}$ \\
\hline Definido & $\begin{array}{l}\text { Os processos são bem compreendidos e } \\
\text { descritos em padrões, procedimentos e } \\
\text { métodos. O que diferencia o nível } 2 \text { do } 3 \text { é o } \\
\text { escopo. No nível } 2 \text {, os padrões e } \\
\text { procedimentos podem ser diferentes em } \\
\text { cada instância do processo. No nível } 3 \text {, há } \\
\text { certa homogeneidade nos padrões e } \\
\text { procedimentos, além de um rigor maior em } \\
\text { sua descrição. }\end{array}$ & Nível 3 & $\begin{array}{l}\text { A integração já é uma realidade. } \\
\text { Praticamente } 100 \% \text { dos requisitos se } \\
\text { encontram integrados. O problema é que a } \\
\text { integração não trouxe os benefícios } \\
\text { esperados, talvez em parte por não ter sido } \\
\text { feita da forma adequada, ou por falta de } \\
\text { conseguir levantar corretamente os } \\
\text { benefícios reais, ficando a sensação de que } \\
\text { não foi tão benéfico quanto deveria. }\end{array}$ \\
\hline $\begin{array}{l}\text { Gerenciado } \\
\text { Quantitati- } \\
\text { vamente }\end{array}$ & $\begin{array}{l}\text { São estabelecidos objetivos quantitativos } \\
\text { para a qualidade e para o desempenho de } \\
\text { processo. A qualidade e o desempenho de } \\
\text { processo são traduzidos em termos } \\
\text { estatísticos e gerenciados ao longo dos } \\
\text { processos. }\end{array}$ & Nível 4 & $\begin{array}{l}\text { A integração é total e se encontra fortemente } \\
\text { ligada ao planejamento estratégico, sendo } \\
\text { que no desdobramento do plano estratégico } \\
\text { estão indicadores quantitativos diretamente } \\
\text { relacionados com os objetivos do SGI. }\end{array}$ \\
\hline Otimizado & $\begin{array}{l}\text { O foco é na melhoria contínua do } \\
\text { desempenho do processo através de } \\
\text { melhorias incrementais e inovadoras. Os } \\
\text { objetivos quantitativos das melhorias de } \\
\text { processo são continuamente revisados para } \\
\text { refletir as mudanças no nível estratégico. }\end{array}$ & Nível 5 & $\begin{array}{l}\text { Há uma revisão contínua dos indicadores } \\
\text { quantitativos definidos no nível } 4 \text {. }\end{array}$ \\
\hline
\end{tabular}

Figura 12 - Comparação entre os níveis de maturidade do CMMI e da Ferramenta de Avaliação do Grau de Maturidade em SGI 
Ao total foram desenvolvidas três versões da mesma ferramenta. A primeira versão apresentada a serguir na Figura 13 foi avaliada por especialistas acadêmicos dando origem a segunda versão (ferramenta que foi apresentado aos profissionais da indústria). Tal versão apresentada aos profissionais da indútria sofreu pouca alteração quando comparada à terceira versão que será apresentada no próximo tópico (Figura 14).

Antes de apresentar a ferramenta, é importante distinguir dois conceitos que foram definidos de acordo com Baldrige Performance Excellence Program (2013) e que serão utilizados na ferramenta:

- Alinhamento: A palavra principal é consistência. O alinhamento efetivo requer um entendimento comum de objetivos e metas.

- Integração: A palavra principal é harmonização. A integração efetiva vai além do alinhamento e é alcançada quando os componentes individuais operam como uma unidade totalmente conectada.

\begin{tabular}{|c|c|c|c|c|c|}
\hline & INICIAL & GERENCIADO & $\begin{array}{c}\text { DEFINIDO/ } \\
\text { PADRONIZADO }\end{array}$ & $\begin{array}{c}\text { GERENCIADO } \\
\text { QUANTITATIV } \\
\text { AMENTE }\end{array}$ & OTMIZADO \\
\hline \multicolumn{6}{|l|}{ POLÍTICA } \\
\hline $\begin{array}{l}\text { Existência de } \\
\text { política }\end{array}$ & $\begin{array}{l}\text { Cada norma } \\
\text { possui sua própria } \\
\text { política }\end{array}$ & $\begin{array}{l}\text { As políticas se } \\
\text { mantem } \\
\text { separadas, mas há } \\
\text { um alinhamento } \\
\text { entre elas }\end{array}$ & $\begin{array}{l}\text { Há uma única } \\
\text { política que } \\
\text { representa as } \\
\text { normas integradas }\end{array}$ & $\begin{array}{l}\text { A política } \\
\text { integrada está } \\
\text { alinhada com o } \\
\text { planejamento } \\
\text { estratégico da } \\
\text { empresa }\end{array}$ & $\begin{array}{l}\text { Na política } \\
\text { integrada há } \\
\text { referência para a } \\
\text { melhoria contínua } \\
\text { do SGI, além de } \\
\text { estar alinhada } \\
\text { com o } \\
\text { planejamento } \\
\text { estratégico }\end{array}$ \\
\hline $\begin{array}{l}\text { Participação } \\
\text { da Alta } \\
\text { Administração }\end{array}$ & $\begin{array}{l}\text { Demonstra não ter } \\
\text { conhecimento } \\
\text { efetivo sobre a } \\
\text { Política }\end{array}$ & $\begin{array}{l}\text { Teve contato com } \\
\text { a política apenas } \\
\text { quando a mesma } \\
\text { já estava pronta, } \\
\text { não contribuindo } \\
\text { com a elaboração } \\
\text { da mesma }\end{array}$ & $\begin{array}{l}\text { Participou, mas de } \\
\text { forma não muito } \\
\text { ativa }\end{array}$ & $\begin{array}{l}\text { Participou } \\
\text { ativamente da } \\
\text { elaboração da } \\
\text { política }\end{array}$ & $\begin{array}{l}\text { Participou } \\
\text { ativamente e } \\
\text { busca melhorar } \\
\text { continuamente a } \\
\text { política }\end{array}$ \\
\hline $\begin{array}{l}\text { Atualização e } \\
\text { documentação } \\
\text { da política }\end{array}$ & $\begin{array}{l}\text { Não é dada } \\
\text { importância para a } \\
\text { documentação da } \\
\text { política e para sua } \\
\text { atualização }\end{array}$ & $\begin{array}{l}\text { A empresa possui } \\
\text { uma política } \\
\text { documentada e já } \\
\text { realizou ou } \\
\text { pretende realizar } \\
\text { revisão quando } \\
\text { necessário }\end{array}$ & $\begin{array}{l}\text { A política está } \\
\text { documentada e } \\
\text { realiza atualização } \\
\text { de forma } \\
\text { sistematizada }\end{array}$ & $\begin{array}{l}\text { A política é } \\
\text { atualizada } \\
\text { conforme há } \\
\text { atualização do } \\
\text { planejamento } \\
\text { estratégico }\end{array}$ & $\begin{array}{l}\text { A política é } \\
\text { atualizada } \\
\text { conforme surge a } \\
\text { necessidade e } \\
\text { isso já faz parte } \\
\text { do processo de } \\
\text { melhoria contínua }\end{array}$ \\
\hline
\end{tabular}

Figura 13 - Versão inicial da Ferramenta de Avaliação do Grau de Maturidade em SGI (continua) 


\begin{tabular}{|c|c|c|c|c|c|}
\hline $\begin{array}{l}\text { Divulgação da } \\
\text { política }\end{array}$ & $\begin{array}{l}\text { Não há } \\
\text { preocupação com } \\
\text { a divulgação da } \\
\text { política }\end{array}$ & $\begin{array}{l}\text { Há divulgação da } \\
\text { política, mas não } \\
\text { envolve a todos } \\
\text { que trabalham na } \\
\text { empresa ou que } \\
\text { atuem em seu } \\
\text { nome }\end{array}$ & $\begin{array}{l}\text { A divulgação é feita } \\
\text { de forma que todos } \\
\text { que trabalham na } \\
\text { empresa ou atuem } \\
\text { em seu nome } \\
\text { estejam cientes da } \\
\text { mesma, porém isso } \\
\text { é feito somente uma } \\
\text { vez }\end{array}$ & $\begin{array}{l}\text { A divulgação } \\
\text { ocorre de } \\
\text { maneira } \\
\text { frequênte, mas } \\
\text { de acordo com a } \\
\text { necessidade } \\
\text { apontada por } \\
\text { uma área } \\
\text { específica }\end{array}$ & $\begin{array}{l}\text { A divulgação é } \\
\text { feita com uma } \\
\text { periodicidade } \\
\text { pré-estabelecida } \\
\text { para garantir que } \\
\text { as pessoas não se } \\
\text { esqueçam }\end{array}$ \\
\hline \multicolumn{6}{|c|}{ PLANEJAMENTO } \\
\hline $\begin{array}{l}\text { Elaboração do } \\
\text { planejamento }\end{array}$ & $\begin{array}{l}\text { O planejamento } \\
\text { das normas é feito } \\
\text { de forma separada }\end{array}$ & $\begin{array}{l}\text { O planejamento } \\
\text { das normas é feito } \\
\text { de forma } \\
\text { conjunta, porém } \\
\text { na hora de colocar } \\
\text { no papel cada } \\
\text { norma é } \\
\text { considerada em } \\
\text { planos separados }\end{array}$ & $\begin{array}{l}\text { O planejamento é } \\
\text { feito de forma } \\
\text { conjunta e como } \\
\text { resultado a } \\
\text { empresa apresenta } \\
\text { um único plano }\end{array}$ & $\begin{array}{l}\text { O planejamento } \\
\text { é feito de forma } \\
\text { conjunta, a } \\
\text { empresa possui } \\
\text { um único plano } \\
\text { e são } \\
\text { estabelecidos } \\
\text { metas } \\
\text { quantitativas/ } \\
\text { qualitativas para } \\
\text { acompanhar a } \\
\text { implantação do } \\
\text { plano }\end{array}$ & $\begin{array}{l}\text { O planejamento é } \\
\text { revisado } \\
\text { constantemente }\end{array}$ \\
\hline $\begin{array}{l}\text { Requisitos das } \\
\text { normas }\end{array}$ & $\begin{array}{l}\text { Nem todos os } \\
\text { requisitos das } \\
\text { normas são } \\
\text { considerados no } \\
\text { planejamento }\end{array}$ & $\begin{array}{l}\text { Considera-se } \\
\text { todos os } \\
\text { requisitos, porém } \\
\text { não se preocupa } \\
\text { com a } \\
\text { compatibilidade } \\
\text { entre eles }\end{array}$ & $\begin{array}{l}\text { Considera-se todos } \\
\text { os requisitos e é } \\
\text { feito uma análise } \\
\text { de compatibilidade } \\
\text { entre eles }\end{array}$ & $\begin{array}{l}\text { Considera-se } \\
\text { todos os } \\
\text { requisitos e } \\
\text { busca-se } \\
\text { relacioná-los } \\
\text { com a estratégia } \\
\text { da empresa }\end{array}$ & $\begin{array}{l}\text { Os requisitos são } \\
\text { avaliados } \\
\text { constantemente }\end{array}$ \\
\hline $\begin{array}{l}\text { Equipe que } \\
\text { realiza o } \\
\text { planejamento }\end{array}$ & $\begin{array}{l}\text { Cada norma é } \\
\text { feita por uma } \\
\text { equipe diferente e } \\
\text { que geralmente é } \\
\text { formada de } \\
\text { acordo com a } \\
\text { disponibilidade de } \\
\text { tempo }\end{array}$ & $\begin{array}{l}\text { O planejamento é } \\
\text { feito por uma } \\
\text { única equipe } \\
\text { formada de } \\
\text { acordo com a } \\
\text { disponibilidade de } \\
\text { tempo }\end{array}$ & $\begin{array}{l}\text { O planejamento é } \\
\text { feito por uma única } \\
\text { equipe tendo como } \\
\text { critério de seleção } \\
\text { para participar } \\
\text { dessa equipe o } \\
\text { conhecimento das } \\
\text { normas }\end{array}$ & $\begin{array}{l}\text { O planejamento } \\
\text { é feito } \\
\text { envolvendo } \\
\text { pessoas do nível } \\
\text { operacional e } \\
\text { estratégico }\end{array}$ & $\begin{array}{l}\text { O planejamento é } \\
\text { visto como algo } \\
\text { de suma } \\
\text { importância e faz } \\
\text { parte da rotina } \\
\text { dos integrantes } \\
\text { estar sempre } \\
\text { atento a } \\
\text { necessidade de } \\
\text { mudanças nele }\end{array}$ \\
\hline $\begin{array}{l}\text { Objetivos e } \\
\text { metas }\end{array}$ & $\begin{array}{l}\text { Objetivos e metas } \\
\text { não são alinhados } \\
\text { e integrados }\end{array}$ & $\begin{array}{l}\text { Objetivos e metas } \\
\text { estão alinhados, } \\
\text { embora não sejam } \\
\text { integrados }\end{array}$ & $\begin{array}{l}\text { Objetivos e metas } \\
\text { estão alinhados e } \\
\text { são integrados }\end{array}$ & $\begin{array}{l}\text { Objetivos e } \\
\text { metas estão } \\
\text { alinhados entre } \\
\text { eles e com o } \\
\text { planejamento } \\
\text { estratégico e são } \\
\text { integrados }\end{array}$ & $\begin{array}{l}\text { Objetivos e metas } \\
\text { estão alinhados } \\
\text { entre eles e com o } \\
\text { planejamento } \\
\text { estratégico; são } \\
\text { integrados e } \\
\text { revisados } \\
\text { periodicamente }\end{array}$ \\
\hline
\end{tabular}

Figura 13 - Versão inicial da Ferramenta de Avaliação do Grau de Maturidade em SGI (continuação) 


\begin{tabular}{|c|c|c|c|c|c|}
\hline \multicolumn{6}{|c|}{ IMPLEMENTAÇÃO } \\
\hline $\begin{array}{l}\text { Funções, } \\
\text { responsabili- } \\
\text { des e } \\
\text { autoridades }\end{array}$ & $\begin{array}{l}\text { Há pontos falhos } \\
\text { em termos de } \\
\text { documentação e } \\
\text { comunicação, } \\
\text { sendo que } \\
\text { algumas pessoas } \\
\text { ficam em dúvida } \\
\text { sobre quais são } \\
\text { suas funções, } \\
\text { responsabilidades } \\
\text { e autoridades }\end{array}$ & $\begin{array}{l}\text { Há pontos falhos } \\
\text { em termos de } \\
\text { documentação e } \\
\text { comunicação, } \\
\text { embora esteja } \\
\text { claro a todos suas } \\
\text { funções, } \\
\text { responsabilidades } \\
\text { e autoridades }\end{array}$ & $\begin{array}{l}\text { Estão bem definidas, } \\
\text { documentadas e } \\
\text { comunicadas as } \\
\text { funções, } \\
\text { responsabilidades e } \\
\text { autoridades de todos }\end{array}$ & $\begin{array}{l}\text { As funções, } \\
\text { responsabilidades } \\
\text { e autoridades } \\
\text { estão claras a } \\
\text { todos e alinhadas } \\
\text { com o } \\
\text { planejamento } \\
\text { estratégico }\end{array}$ & $\begin{array}{l}\text { As funções, } \\
\text { responsabilidades } \\
\text { e autoridades são } \\
\text { revisadas } \\
\text { constantemente } \\
\text { para se adaptar as } \\
\text { mudanças }\end{array}$ \\
\hline $\begin{array}{l}\text { Equipe que } \\
\text { realiza a } \\
\text { implantação }\end{array}$ & $\begin{array}{l}\text { Para implantação } \\
\text { não é formada } \\
\text { uma equipe e cada } \\
\text { norma tem um } \\
\text { responsável pela } \\
\text { implantação, o } \\
\text { qual realiza seu } \\
\text { trabalho } \\
\text { envolvendo } \\
\text { poucas pessoas e } \\
\text { geralmente sem } \\
\text { interagir com os } \\
\text { responsáveis pela } \\
\text { implantação das } \\
\text { outras normas }\end{array}$ & $\begin{array}{l}\text { A implantação é } \\
\text { feita por uma } \\
\text { equipe que tem } \\
\text { conhecimento das } \\
\text { normas, mas que } \\
\text { não consegue o } \\
\text { envolvimento de } \\
\text { todos por isso } \\
\text { acaba ficando } \\
\text { tudo em suas } \\
\text { mãos }\end{array}$ & $\begin{array}{l}\text { A implantação é feita } \\
\text { por uma equipe } \\
\text { multidisciplinar tendo } \\
\text { como critério de } \\
\text { seleção para participar } \\
\text { dessa equipe o } \\
\text { conhecimento das } \\
\text { normas e procurando } \\
\text { envolver a todos a } \\
\text { nível operacional }\end{array}$ & $\begin{array}{l}\text { A implantação é } \\
\text { feita por uma } \\
\text { equipe } \\
\text { multidisciplinar } \\
\text { que conhece } \\
\text { amplamente as } \\
\text { normas e que } \\
\text { envolvendo } \\
\text { pessoas tantdo do } \\
\text { nível operacional } \\
\text { e como } \\
\text { estratégico }\end{array}$ & $\begin{array}{l}\text { A implantação é } \\
\text { visto como algo } \\
\text { de suma } \\
\text { importância e faz } \\
\text { parte da rotina } \\
\text { dos integrantes } \\
\text { estar sempre } \\
\text { atento a } \\
\text { necessidade de } \\
\text { mudanças nele }\end{array}$ \\
\hline $\begin{array}{l}\text { Recursos } \\
\text { (humanos, } \\
\text { infra- } \\
\text { estrutura, } \\
\text { financeiro) }\end{array}$ & $\begin{array}{l}\text { Não há recursos } \\
\text { suficientes e } \\
\text { muito menos são } \\
\text { divididos de } \\
\text { forma igualitária } \\
\text { entre as normas }\end{array}$ & $\begin{array}{l}\text { Os recursos são } \\
\text { disponibilizados } \\
\text { de forma } \\
\text { suficiente, mas há } \\
\text { um certo } \\
\text { desiquilíbrio na } \\
\text { divisão deles } \\
\text { relacionados as } \\
\text { normas, ou seja, } \\
\text { algumas normas } \\
\text { recebem mais } \\
\text { recursos que } \\
\text { outras }\end{array}$ & $\begin{array}{l}\text { Há recursos } \\
\text { suficientes e estão } \\
\text { disponibilizados de } \\
\text { forma equilibrada } \\
\text { entre as normas }\end{array}$ & $\begin{array}{l}\text { Há recursos } \\
\text { suficientes, estão } \\
\text { disponibilizados } \\
\text { de forma } \\
\text { equilibrada entre } \\
\text { as normas e é } \\
\text { dado prioridade } \\
\text { para a } \\
\text { disponibilização } \\
\text { desses recursos, } \\
\text { ou seja, em uma } \\
\text { crise esses } \\
\text { recursos são } \\
\text { dificilmente } \\
\text { cortados }\end{array}$ & $\begin{array}{l}\text { Há recursos } \\
\text { suficientes, estão } \\
\text { disponibilizados } \\
\text { de forma } \\
\text { equilibrada entre } \\
\text { as normas e são } \\
\text { avaliados } \\
\text { constantemente } \\
\text { se os recursos são } \\
\text { suficientes }\end{array}$ \\
\hline
\end{tabular}

Figura 13 - Versão inicial da Ferramenta de Avaliação do Grau de Maturidade em SGI (continuação) 


\begin{tabular}{|c|c|c|c|c|c|}
\hline Treinamentos & $\begin{array}{l}\text { Os } \\
\text { treinamentos } \\
\text { são feitos } \\
\text { procurando } \\
\text { contemplar as } \\
\text { necessidades } \\
\text { das normas em } \\
\text { separado. Não } \\
\text { costuma-se } \\
\text { manter } \\
\text { registros de } \\
\text { treinamento e } \\
\text { quando são } \\
\text { mantidos, esses } \\
\text { registros ficam } \\
\text { guardados de } \\
\text { forma } \\
\text { separada. }\end{array}$ & $\begin{array}{l}\text { Alguns } \\
\text { treinamentos são } \\
\text { montados tendo } \\
\text { em vista a } \\
\text { preocupação com } \\
\text { mais de uma } \\
\text { norma, mas isso } \\
\text { não é regra e os } \\
\text { registros podem } \\
\text { ou não ser } \\
\text { mantidos em } \\
\text { conjunto }\end{array}$ & $\begin{array}{l}\text { Os treinamentos são } \\
\text { montados procurando } \\
\text { levar em consideração } \\
\text { o maior número de } \\
\text { normas possíveis ou } \\
\text { que possam impactar } \\
\text { no assunto abordado } \\
\text { no treinamento. Os } \\
\text { registros do } \\
\text { treinamento são } \\
\text { gerenciados de forma } \\
\text { integrada }\end{array}$ & $\begin{array}{l}\text { Os treinamentos } \\
\text { são montados } \\
\text { levantando em } \\
\text { consideração a } \\
\text { interação entre as } \\
\text { normas, os } \\
\text { registros são } \\
\text { mantidos em } \\
\text { conjunto e a alta } \\
\text { administração está } \\
\text { sempre informada } \\
\text { sobre os } \\
\text { treinamentos que } \\
\text { ocorrem, havendo } \\
\text { indicadores que } \\
\text { ajudam a ver quão } \\
\text { efetivos são os } \\
\text { treinamentos }\end{array}$ & $\begin{array}{l}\text { Os treinamentos } \\
\text { são revisados } \\
\text { constantemente } \\
\text { de acordo com os } \\
\text { resultados de suas } \\
\text { avaliações e } \\
\text { efetividade } \\
\text { (eficiência e } \\
\text { eficácia) }\end{array}$ \\
\hline $\begin{array}{l}\text { Avaliação dos } \\
\text { treinamentos }\end{array}$ & $\begin{array}{l}\text { A avaliação de } \\
\text { eficácia é feita } \\
\text { apenas para } \\
\text { cumprir } \\
\text { requisitos da } \\
\text { auditoria }\end{array}$ & $\begin{array}{l}\text { A avaliação de } \\
\text { eficácia ocorre } \\
\text { mais para cumprir } \\
\text { os requisitos, } \\
\text { embora busque-se } \\
\text { fazer uma análise } \\
\text { da avaliação } \\
\text { procurando } \\
\text { utilizar esses } \\
\text { dados para a } \\
\text { melhoria dos } \\
\text { treinamentos }\end{array}$ & $\begin{array}{l}\text { A avaliação de } \\
\text { eficácia não é feita } \\
\text { apenas para cumprir } \\
\text { requisitos, mas } \\
\text { também com o intuito } \\
\text { de melhorar os } \\
\text { treinamentos, embora } \\
\text { não haja indicadores e } \\
\text { metas a serem } \\
\text { alcançadas }\end{array}$ & $\begin{array}{l}\text { Há indicadores e } \\
\text { metas que são } \\
\text { amplamente } \\
\text { divulgados } \\
\text { inclusive para a } \\
\text { alta administração } \\
\text { sobre a avaliação } \\
\text { dos treinamentos }\end{array}$ & $\begin{array}{l}\text { Os indicadores e } \\
\text { metas auxiliam } \\
\text { no processo de } \\
\text { melhoria contínua } \\
\text { dos treinamentos }\end{array}$ \\
\hline Manual & $\begin{array}{l}\text { Cada norma } \\
\text { possui seu } \\
\text { próprio manual } \\
\text { e não há } \\
\text { alinhamento } \\
\text { entre eles }\end{array}$ & $\begin{array}{l}\text { Cada norma } \\
\text { possui seu próprio } \\
\text { manual, mas há } \\
\text { alinhamento entre } \\
\text { eles }\end{array}$ & $\begin{array}{l}\text { Há um único manual } \\
\text { que engloba todas as } \\
\text { normas, mas nem } \\
\text { todos o conhecem }\end{array}$ & $\begin{array}{l}\text { Há um único } \\
\text { manual que } \\
\text { engloba todas as } \\
\text { normas, o qual é } \\
\text { amplamente } \\
\text { divulgado }\end{array}$ & $\begin{array}{l}\text { Há um único } \\
\text { manual } \\
\text { amplamente } \\
\text { divulgado e } \\
\text { revisado } \\
\text { constantemente }\end{array}$ \\
\hline $\begin{array}{l}\text { Procedimentos, } \\
\text { instruções e } \\
\text { registros }\end{array}$ & $\begin{array}{l}\text { Procedimentos, } \\
\text { instruções e } \\
\text { registros são } \\
\text { tratados de } \\
\text { forma } \\
\text { completamente } \\
\text { separadas }\end{array}$ & $\begin{array}{l}\text { Procedimentos, } \\
\text { instruções e } \\
\text { registros são } \\
\text { alinhados, embora } \\
\text { não sejam } \\
\text { integrados }\end{array}$ & $\begin{array}{l}\text { Procedimentos, } \\
\text { instruções e registros } \\
\text { são integrados }\end{array}$ & $\begin{array}{l}\text { Procedimentos, } \\
\text { instruções e } \\
\text { registros são } \\
\text { integrados e } \\
\text { amplamente } \\
\text { divulgados }\end{array}$ & $\begin{array}{l}\text { Procedimentos, } \\
\text { instruções e } \\
\text { registros são } \\
\text { revisados } \\
\text { constantemente }\end{array}$ \\
\hline $\begin{array}{l}\text { Controle de } \\
\text { procedimentos, } \\
\text { instruções e } \\
\text { registros }\end{array}$ & $\begin{array}{l}\text { Não há } \\
\text { controle de } \\
\text { procedimentos, } \\
\text { instruções e } \\
\text { registros, } \\
\text { podendo-se } \\
\text { encontrar } \\
\text { documentos } \\
\text { obsoletos }\end{array}$ & $\begin{array}{l}\text { Há controle de } \\
\text { procedimentos, } \\
\text { instruções e } \\
\text { registros, embora } \\
\text { cada norma } \\
\text { possua seu } \\
\text { próprio controle }\end{array}$ & $\begin{array}{l}\text { Há controle de } \\
\text { procedimentos, } \\
\text { instruções e registros } \\
\text { que é feito de forma } \\
\text { integrada }\end{array}$ & $\begin{array}{l}\text { O controle é } \\
\text { supervisionado, } \\
\text { não ficando a } \\
\text { cargo apenas de } \\
\text { quem lida } \\
\text { diretamente com } \\
\text { os procedimentos, } \\
\text { instruções e } \\
\text { registros }\end{array}$ & $\begin{array}{l}\text { O controle é } \\
\text { revisado de } \\
\text { acordo com a } \\
\text { necessidade }\end{array}$ \\
\hline
\end{tabular}

Figura 13 - Versão inicial da Ferramenta de Avaliação do Grau de Maturidade em SGI (continuação) 


\begin{tabular}{|c|c|c|c|c|c|}
\hline Comunicação & $\begin{array}{l}\text { Cada norma tem } \\
\text { um responsável } \\
\text { por sua } \\
\text { comunicação e } \\
\text { não há } \\
\text { integração } \\
\text { nenhuma entre } \\
\text { as normas nesse } \\
\text { momento }\end{array}$ & $\begin{array}{l}\text { Cada norma tem } \\
\text { um responsável } \\
\text { por sua } \\
\text { comunicação, } \\
\text { porém há um } \\
\text { alinhamento entre } \\
\text { essa comunicação }\end{array}$ & $\begin{array}{l}\text { Há uma estrutura } \\
\text { única que cuida de } \\
\text { todo processo de } \\
\text { comunicação das } \\
\text { normas, mas no } \\
\text { momento da } \\
\text { comunicação nem } \\
\text { sempre considera as } \\
\text { normas de forma } \\
\text { integrada }\end{array}$ & $\begin{array}{l}\text { Há uma estrutura } \\
\text { única que cuida } \\
\text { de todo processo } \\
\text { de comunicação } \\
\text { das normas e as } \\
\text { normas são } \\
\text { consideradas de } \\
\text { forma integrada }\end{array}$ & $\begin{array}{l}\text { Há uma estrutura } \\
\text { única que cuida } \\
\text { de todo processo } \\
\text { de comunicação } \\
\text { das normas, as } \\
\text { normas são } \\
\text { consideradas de } \\
\text { forma integrada e } \\
\text { há uma } \\
\text { procupação com } \\
\text { a melhoria desse } \\
\text { processo de } \\
\text { forma constante }\end{array}$ \\
\hline \multicolumn{6}{|l|}{ VERIFICAÇÃO } \\
\hline $\begin{array}{l}\text { Auditoria } \\
\text { interna }\end{array}$ & $\begin{array}{l}\text { As auditorias } \\
\text { internas são } \\
\text { feitas por } \\
\text { equipes } \\
\text { diferentes, em } \\
\text { períodos } \\
\text { diferentes e } \\
\text { geram relatórios } \\
\text { separados }\end{array}$ & $\begin{array}{l}\text { As auditorias } \\
\text { internas são feitas } \\
\text { por uma única } \\
\text { equipe e ao } \\
\text { mesmo tempo, } \\
\text { porém os } \\
\text { relatórios são } \\
\text { separados }\end{array}$ & $\begin{array}{l}\text { As auditorias } \\
\text { internas são feitas } \\
\text { por uma única } \\
\text { equipe e ao mesmo } \\
\text { tempo, gerando um } \\
\text { único relatório }\end{array}$ & $\begin{array}{l}\text { O relatório é } \\
\text { analisado } \\
\text { cuidadosamente } \\
\text { pela alta } \\
\text { administração }\end{array}$ & $\begin{array}{l}\text { Ao relatório é } \\
\text { dado muita } \\
\text { importância e ele } \\
\text { serve de base } \\
\text { para a promoção } \\
\text { da melhoria } \\
\text { contínua }\end{array}$ \\
\hline $\begin{array}{l}\text { Auditoria } \\
\text { externa }\end{array}$ & $\begin{array}{l}\text { As auditorias } \\
\text { externas são } \\
\text { feitas por } \\
\text { auditores } \\
\text { diferentes, em } \\
\text { períodos } \\
\text { diferentes e } \\
\text { geram relatórios } \\
\text { separados }\end{array}$ & $\begin{array}{l}\text { A auditoria } \\
\text { externa é feita por } \\
\text { um único auditor, } \\
\text { o qual audita } \\
\text { todas as normas } \\
\text { integradas, porém } \\
\text { são gerados } \\
\text { relatórios } \\
\text { separados }\end{array}$ & $\begin{array}{l}\text { A auditoria externa } \\
\text { é feita por um único } \\
\text { auditor, o qual } \\
\text { audita todas as } \\
\text { normas integradas, } \\
\text { gernado um único } \\
\text { relatório }\end{array}$ & $\begin{array}{l}\text { O relatório é } \\
\text { analisado } \\
\text { cuidadosamente } \\
\text { pela alta } \\
\text { administração }\end{array}$ & $\begin{array}{l}\text { Ao relatório é } \\
\text { dado muita } \\
\text { importância e ele } \\
\text { serve de base } \\
\text { para a promoção } \\
\text { da melhoria } \\
\text { contínua }\end{array}$ \\
\hline $\begin{array}{l}\text { Não } \\
\text { conformidades, } \\
\text { ações corretivas } \\
\text { e preventivas }\end{array}$ & $\begin{array}{l}\text { Não há } \\
\text { integração } \\
\text { alguma desses } \\
\text { itens }\end{array}$ & $\begin{array}{l}\text { Há integração de } \\
\text { alguns itens }\end{array}$ & $\begin{array}{l}\text { Esses itens são } \\
\text { vistos de forma } \\
\text { integradas }\end{array}$ & $\begin{array}{l}\text { A alta } \\
\text { administração } \\
\text { acompanha de } \\
\text { perto esses itens }\end{array}$ & $\begin{array}{l}\text { Esses itens são } \\
\text { usados para } \\
\text { promover a } \\
\text { melhoria contínua }\end{array}$ \\
\hline \multicolumn{6}{|c|}{ ANÁLISE DA ADMINISTRAÇÃO } \\
\hline $\begin{array}{l}\text { Análise da } \\
\text { administração }\end{array}$ & $\begin{array}{l}\text { A análise é feita } \\
\text { de forma } \\
\text { separada e a alta } \\
\text { administração } \\
\text { geralmente } \\
\text { realiza uma } \\
\text { análise para } \\
\text { cumprir } \\
\text { requisito da } \\
\text { norma }\end{array}$ & $\begin{array}{l}\text { A análise é feita } \\
\text { de forma } \\
\text { separada, mas } \\
\text { buscando o } \\
\text { alinhamento entre } \\
\text { as normas e a alta } \\
\text { administração } \\
\text { participa dessa } \\
\text { análise embora } \\
\text { não seja uma } \\
\text { participação } \\
\text { muito ativa }\end{array}$ & $\begin{array}{l}\text { A análise é feita de } \\
\text { forma conjunta e a } \\
\text { alta administração } \\
\text { participa dessa } \\
\text { análise embora não } \\
\text { seja uma } \\
\text { participação muito } \\
\text { ativa }\end{array}$ & $\begin{array}{l}\text { A análise é feita } \\
\text { de forma conjunta } \\
\text { e a alta } \\
\text { administração } \\
\text { participa } \\
\text { ativamente dessa } \\
\text { análise }\end{array}$ & $\begin{array}{l}\text { A análise é feita } \\
\text { de forma } \\
\text { conjunta, a alta } \\
\text { administração } \\
\text { participa } \\
\text { ativamente dessa } \\
\text { análise e utiliza a } \\
\text { mesma para o } \\
\text { processo de } \\
\text { melhoria contínua }\end{array}$ \\
\hline
\end{tabular}

Figura 13 - Versão inicial da Ferramenta de Avaliação do Grau de Maturidade em SGI (final) 
As principais alterações sugeridas pelos especialistas acadêmicos na primeira versão da ferramenta foram:

- Ao invés de nomear os níveis de "inicial”, "gerenciado", e assim por diante, optou-se por apresentá-lo por número conforme pode ser constatado na Figura 14.

- Mudou o conteúdo de diversos itens. Por exemplo, quando se fala a respeito da participação da alta administração, na ferramenta inicial o primeiro nível de maturidade constava "Demonstra não ter conhecimento efetivo sobre a política". No entanto, percebeu-se que não havia menção alguma à integração em si e por isso alterou-se para "A alta administração não prioriza a elaboração de política integrada".

- Procurou-se um maior alinhamento do nível gerenciado "quantitativamente" e "otimizado" para que pudesse haver uma maior coerência entre os itens levando em consideração a descrição da Figura 12.

- Houve a retirada de dois itens que foram "requisitos das normas" e "avaliação dos treinamentos", no entanto dois itens foram acrescentados que são "controle operacional" e "monitoramento e medição (produto, meio ambiente, saúde e segurança, ou outros)".

- Houve alteração da ordem de alguns itens como "manual", "procedimentos, instruções e registros" e "controle de atualização de procedimentos, instruções e registros" que passaram da "Implementação" para "Planejamento".

- Houve exclusão da separação “Análise da Administração" e o item que fazia parte desse tópico foi incorporado ao tópico "Verificação/Ação".

Com relação as alterações sofridas na segunda versão da ferramenta apresentada aos profissionais da indústria, foram mais relacionados a forma de escrita. Um exemplo de alteração foi referente ao item "manual”, onde no nível 4 estava escrito "Há um único manual que engloba todas as normas, o qual é amplamente divulgado" e conforme sugestão foi alterado para "Há um único manual que engloba todas as normas, o qual é distribuído para os setores pertinentes". Outro exemplo de alteração é com relação ao item "monitoramento e medição" que passou a ser chamado de "Monitoramento e medição (produto, meio ambiente, saúde e segurança, ou outros)". Os títulos de alguns tópicos também foram alterados como de "Implementação" que passou a ser chamado de "Implementação/Execução", assim como "Verificação" passando a ser designado por "Verificação/Ação". 


\subsection{Ferramenta de Avaliação do Grau de Maturidade em SGI}

A seguir (Figura 14) é apresentada a versão final da ferramenta de avaliação do grau de maturidade. Ela foi construída com base nas sugestões dadas tanto pelos especialistas acadêmicos como profissionais da indústria. Ela segue a mesma estrutura inicial.

\begin{tabular}{|c|c|c|c|c|c|}
\hline & 1 & 2 & 3 & 4 & 5 \\
\hline \multicolumn{6}{|l|}{ POLÍTICA } \\
\hline $\begin{array}{l}\text { Existência de } \\
\text { política integrada }\end{array}$ & $\begin{array}{l}\text { Cada norma } \\
\text { possui sua } \\
\text { própria política }\end{array}$ & $\begin{array}{l}\text { Cada norma } \\
\text { possui sua } \\
\text { própria política e } \\
\text { há um } \\
\text { alinhamento entre } \\
\text { elas de forma a } \\
\text { evitar } \\
\text { contradições }\end{array}$ & $\begin{array}{l}\text { Há uma única } \\
\text { política que } \\
\text { representa todas } \\
\text { as normas } \\
\text { integradas }\end{array}$ & $\begin{array}{l}\text { Há uma única } \\
\text { política que } \\
\text { representa todas } \\
\text { as normas } \\
\text { integradas. Os } \\
\text { itens da política } \\
\text { estão alinhados } \\
\text { com o plano } \\
\text { estratégico e são } \\
\text { desdobrados em } \\
\text { indicadores } \\
\text { quantitativos }\end{array}$ & $\begin{array}{l}\text { Há uma única } \\
\text { política que } \\
\text { representa todas } \\
\text { as normas } \\
\text { integradas. Os } \\
\text { itens da política } \\
\text { estão alinhados } \\
\text { com o plano } \\
\text { estratégico e são } \\
\text { desdobrados em } \\
\text { indicadores } \\
\text { quantitativos } \\
\text { constantemente } \\
\text { revisados }\end{array}$ \\
\hline $\begin{array}{l}\text { Participação da } \\
\text { Alta } \\
\text { Administração }\end{array}$ & $\begin{array}{l}\text { A Alta } \\
\text { Administração } \\
\text { não prioriza a } \\
\text { elaboração de } \\
\text { uma política } \\
\text { integrada }\end{array}$ & $\begin{array}{l}\text { A Alta } \\
\text { Administração } \\
\text { prioriza a } \\
\text { elaboração de } \\
\text { uma política } \\
\text { integrada, } \\
\text { atuando como } \\
\text { patrocinadora }\end{array}$ & $\begin{array}{l}\text { A Alta } \\
\text { Administração } \\
\text { teve papel } \\
\text { importante na } \\
\text { integração da } \\
\text { política, pois } \\
\text { atuou como } \\
\text { patrocinadora e } \\
\text { participou } \\
\text { ativamente da } \\
\text { elaboração da } \\
\text { mesma }\end{array}$ & $\begin{array}{l}\text { A Alta } \\
\text { Administração } \\
\text { teve papel } \\
\text { importante na } \\
\text { integração da } \\
\text { política, pois } \\
\text { atuou como } \\
\text { patrocinadora e } \\
\text { participou } \\
\text { ativamente da } \\
\text { elaboração da } \\
\text { mesma, além de } \\
\text { realizar } \\
\text { avaliações para } \\
\text { verificar a } \\
\text { implantação da } \\
\text { política }\end{array}$ & $\begin{array}{l}\text { A Alta } \\
\text { Administração } \\
\text { teve papel } \\
\text { importante na } \\
\text { integração da } \\
\text { política, pois } \\
\text { atuou como } \\
\text { patrocinadora e } \\
\text { participou } \\
\text { ativamente da } \\
\text { elaboração da } \\
\text { mesma, além de } \\
\text { realizar } \\
\text { avaliações para } \\
\text { verificar a } \\
\text { implantação da } \\
\text { política e validá- } \\
\text { lá } \\
\text { constantemente, } \\
\text { revisando quando } \\
\text { necessário }\end{array}$ \\
\hline
\end{tabular}

Figura 14 - Ferramenta de Avaliação do Grau de Maturidade em SGI (continua) 


\begin{tabular}{|c|c|c|c|c|c|}
\hline $\begin{array}{l}\text { Atualização } \\
\text { da política }\end{array}$ & $\begin{array}{l}\text { A atualização das } \\
\text { diferentes políticas } \\
\text { são feitas com } \\
\text { foco na } \\
\text { certificação e de } \\
\text { forma desintegrada }\end{array}$ & $\begin{array}{l}\text { Há uma grande } \\
\text { preocupação com } \\
\text { a atualização das } \\
\text { diferentes } \\
\text { políticas, buscando } \\
\text { sempre mantê-las } \\
\text { alinhadas }\end{array}$ & $\begin{array}{l}\text { Há grande } \\
\text { preocupação com } \\
\text { a atualização da } \\
\text { política integrada }\end{array}$ & $\begin{array}{l}\text { Há grande } \\
\text { preocupação com } \\
\text { a atualização da } \\
\text { política integrada, } \\
\text { sendo } \\
\text { rigorosamente } \\
\text { controlado }\end{array}$ & $\begin{array}{l}\text { Há grande } \\
\text { preocupação com } \\
\text { a atualização da } \\
\text { política integrada, } \\
\text { sendo } \\
\text { rigorosamente } \\
\text { controlado e } \\
\text { prezando pela } \\
\text { melhoria contínua } \\
\text { desse processo }\end{array}$ \\
\hline $\begin{array}{l}\text { Divulgação } \\
\text { da política }\end{array}$ & $\begin{array}{l}\text { Há divulgação das } \\
\text { políticas em } \\
\text { separado e isso é } \\
\text { feita uma única } \\
\text { vez. Essa } \\
\text { divulgação } \\
\text { envolve parte dos } \\
\text { que trabalham na } \\
\text { empresa ou que } \\
\text { atuam em seu } \\
\text { nome }\end{array}$ & $\begin{array}{l}\text { Há divulgação das } \\
\text { políticas em } \\
\text { separado e a } \\
\text { mesma envolve } \\
\text { todos que } \\
\text { trabalham na } \\
\text { empresa ou que } \\
\text { atuam em seu } \\
\text { nome. Essa } \\
\text { divulgação é feita } \\
\text { de modo frequente }\end{array}$ & $\begin{array}{l}\text { A divulgação da } \\
\text { política integrada é } \\
\text { feita de forma que } \\
\text { todos que } \\
\text { trabalham na } \\
\text { empresa ou atuam } \\
\text { em seu nome } \\
\text { estejam cientes da } \\
\text { mesma. Essa } \\
\text { divulgação é feita } \\
\text { de modo frequente }\end{array}$ & $\begin{array}{l}\text { A divulgação da } \\
\text { política integrada é } \\
\text { feita de forma que } \\
\text { todos que } \\
\text { trabalham na } \\
\text { empresa ou atuam } \\
\text { em seu nome } \\
\text { estejam cientes da } \\
\text { mesma. A } \\
\text { divulgação ocorre } \\
\text { de maneira } \\
\text { frequente e um } \\
\text { controle por } \\
\text { intermédio de } \\
\text { indicadores é feito } \\
\text { para verificar o } \\
\text { quanto as pessoas } \\
\text { a conhecem }\end{array}$ & $\begin{array}{l}\text { A divulgação da } \\
\text { política integrada é } \\
\text { feita de forma que } \\
\text { todos que } \\
\text { trabalham na } \\
\text { empresa ou atuam } \\
\text { em seu nome } \\
\text { estejam cientes da } \\
\text { mesma. A } \\
\text { divulgação ocorre } \\
\text { de maneira } \\
\text { frequente. Um } \\
\text { controle por } \\
\text { intermédio de } \\
\text { indicadores é feito } \\
\text { para verificar o } \\
\text { quanto as pessoas } \\
\text { a conhecem, sendo } \\
\text { que ações são } \\
\text { tomadas com base } \\
\text { nisso visando a } \\
\text { melhoria contínua } \\
\text { do processo de } \\
\text { divulgação }\end{array}$ \\
\hline \multicolumn{6}{|c|}{ PLANEJAMENTO } \\
\hline $\begin{array}{l}\text { Elaboração } \\
\text { do } \\
\text { planejamento }\end{array}$ & $\begin{array}{l}\text { O planejamento } \\
\text { das normas é feito } \\
\text { de forma } \\
\text { independente }\end{array}$ & $\begin{array}{l}\text { O planejamento } \\
\text { das normas é feito } \\
\text { de forma conjunta } \\
\text { e no momento de } \\
\text { registrar no papel } \\
\text { eles são } \\
\text { considerados de } \\
\text { forma separadas }\end{array}$ & $\begin{array}{l}\text { O planejamento é } \\
\text { feito de forma } \\
\text { conjunta e como } \\
\text { resultado a } \\
\text { empresa apresenta } \\
\text { um único plano }\end{array}$ & $\begin{array}{l}\text { O planejamento é } \\
\text { feito de forma } \\
\text { conjunta, a } \\
\text { empresa possui um } \\
\text { único plano e são } \\
\text { estabelecidos } \\
\text { metas } \\
\text { quantitativas/ } \\
\text { qualitativas para } \\
\text { acompanhar a } \\
\text { implantação do } \\
\text { plano }\end{array}$ & $\begin{array}{l}\text { O planejamento é } \\
\text { feito de forma } \\
\text { conjunta, a } \\
\text { empresa possui um } \\
\text { único plano e são } \\
\text { estabelecidos } \\
\text { metas } \\
\text { quantitativas/ } \\
\text { qualitativas para } \\
\text { acompanhar a } \\
\text { implantação do } \\
\text { plano. É feita uma } \\
\text { revisão periódica } \\
\text { do mesmo. }\end{array}$ \\
\hline
\end{tabular}

Figura 14 - Ferramenta de Avaliação do Grau de Maturidade em SGI (continuação) 


\begin{tabular}{|c|c|c|c|c|c|}
\hline $\begin{array}{l}\text { Equipe que } \\
\text { realiza o } \\
\text { planejamento }\end{array}$ & $\begin{array}{l}\text { O planejamento é } \\
\text { feito } \\
\text { separadamente, } \\
\text { ou seja, cada } \\
\text { norma conta com } \\
\text { equipe própria } \\
\text { para fazer o } \\
\text { planejamento e } \\
\text { geralmente a } \\
\text { equipe é formada } \\
\text { de acordo com a } \\
\text { disponibilidade } \\
\text { de tempo }\end{array}$ & $\begin{array}{l}\text { O planejamento } \\
\text { das normas é } \\
\text { feito por uma } \\
\text { única equipe, } \\
\text { normalmente } \\
\text { formada de } \\
\text { acordo com a } \\
\text { disponibilidade } \\
\text { de tempo e } \\
\text { preocupada com } \\
\text { o alinhamento } \\
\text { entre os planos }\end{array}$ & $\begin{array}{l}\text { O planejamento } \\
\text { das normas é } \\
\text { feito por uma } \\
\text { única equipe } \\
\text { tendo como } \\
\text { critério de } \\
\text { seleção para } \\
\text { participar dessa } \\
\text { equipe o } \\
\text { conhecimento } \\
\text { das normas. }\end{array}$ & $\begin{array}{l}\text { O planejamento } \\
\text { das normas é feito } \\
\text { por uma única } \\
\text { equipe tendo como } \\
\text { critério de seleção } \\
\text { para participar } \\
\text { dessa equipe o } \\
\text { conhecimento das } \\
\text { normas. O } \\
\text { planejamento é } \\
\text { feito envolvendo } \\
\text { pessoas do nível } \\
\text { operacional e } \\
\text { estratégico. Há } \\
\text { indicadores que } \\
\text { avaliam o } \\
\text { desempenho da } \\
\text { equipe durante o } \\
\text { planejamento }\end{array}$ & $\begin{array}{l}\text { O planejamento } \\
\text { das normas é feito } \\
\text { por uma única } \\
\text { equipe tendo como } \\
\text { critério de seleção } \\
\text { para participar } \\
\text { dessa equipe o } \\
\text { conhecimento das } \\
\text { normas. O } \\
\text { planejamento é } \\
\text { feito envolvendo } \\
\text { pessoas do nível } \\
\text { operacional e } \\
\text { estratégico. Há } \\
\text { indicadores que } \\
\text { avaliam o } \\
\text { desempenho da } \\
\text { equipe durante o } \\
\text { planejamento, o } \\
\text { qual é revisto } \\
\text { periodicamente }\end{array}$ \\
\hline $\begin{array}{l}\text { Objetivos, metas } \\
\text { e requisitos }\end{array}$ & $\begin{array}{l}\text { Objetivos, metas } \\
\text { e requisitos são } \\
\text { tratados de forma } \\
\text { independentes }\end{array}$ & $\begin{array}{l}\text { Objetivos, metas } \\
\text { e requisitos são } \\
\text { tratados de forma } \\
\text { independentes e } \\
\text { ao mesmo tempo } \\
\text { alinhadas }\end{array}$ & $\begin{array}{l}\text { Objetivos, metas } \\
\text { e requisitos estão } \\
\text { alinhados e são } \\
\text { integrados }\end{array}$ & $\begin{array}{l}\text { Objetivos, metas e } \\
\text { requisitos estão } \\
\text { alinhados e } \\
\text { integrados, além de } \\
\text { serem desdobrados } \\
\text { em indicadores } \\
\text { quantitativos que } \\
\text { são medidos para } \\
\text { verificarem o } \\
\text { quanto atendem os } \\
\text { objetivos }\end{array}$ & $\begin{array}{l}\text { Objetivos, metas e } \\
\text { requisitos estão } \\
\text { alinhados e } \\
\text { integrados, além de } \\
\text { serem desdobrados } \\
\text { em indicadores } \\
\text { quantitativos que } \\
\text { são medidos para } \\
\text { verificarem o } \\
\text { quanto atendem os } \\
\text { objetivos e quando } \\
\text { não estão } \\
\text { adequados, planos } \\
\text { de ação são feitos }\end{array}$ \\
\hline Manual & $\begin{array}{l}\text { Cada norma } \\
\text { possui seu } \\
\text { próprio manual }\end{array}$ & $\begin{array}{l}\text { Cada norma } \\
\text { possui seu } \\
\text { próprio manual e } \\
\text { há um } \\
\text { alinhamento } \\
\text { entre eles }\end{array}$ & $\begin{array}{l}\text { Há um único } \\
\text { manual que } \\
\text { engloba todas as } \\
\text { normas }\end{array}$ & $\begin{array}{l}\text { Há um único } \\
\text { manual que } \\
\text { engloba todas as } \\
\text { normas, o qual é } \\
\text { distribuído para os } \\
\text { setores pertinentes }\end{array}$ & $\begin{array}{l}\text { Há um único } \\
\text { manual que } \\
\text { engloba todas as } \\
\text { normas, o qual é } \\
\text { distribuído para os } \\
\text { setores pertinentes } \\
\text { e suas informações } \\
\text { estão enraizadas na } \\
\text { organização }\end{array}$ \\
\hline $\begin{array}{l}\text { Procedimentos, } \\
\text { instruções e } \\
\text { registros }\end{array}$ & $\begin{array}{l}\text { Procedimentos, } \\
\text { instruções e } \\
\text { registros são } \\
\text { tratados de forma } \\
\text { completamente } \\
\text { separadas }\end{array}$ & $\begin{array}{l}\text { Procedimentos, } \\
\text { instruções e } \\
\text { registros são } \\
\text { tratados de forma } \\
\text { separadas e } \\
\text { alinhadas }\end{array}$ & $\begin{array}{l}\text { Procedimentos, } \\
\text { instruções e } \\
\text { registros são } \\
\text { integrados }\end{array}$ & $\begin{array}{l}\text { Procedimentos, } \\
\text { instruções e } \\
\text { registros são } \\
\text { integrados e } \\
\text { divulgados }\end{array}$ & $\begin{array}{l}\text { Procedimentos, } \\
\text { instruções e } \\
\text { registros são } \\
\text { integrados e } \\
\text { divulgados, sendo } \\
\text { que as informações } \\
\text { contidas estão } \\
\text { enraizadas em toda } \\
\text { organização }\end{array}$ \\
\hline
\end{tabular}

Figura 14 - Ferramenta de Avaliação do Grau de Maturidade em SGI (continuação) 


\begin{tabular}{|c|c|c|c|c|c|}
\hline $\begin{array}{l}\text { Controle de } \\
\text { atualização e } \\
\text { aprovação de } \\
\text { procedimentos, } \\
\text { instruções e } \\
\text { registros }\end{array}$ & $\begin{array}{l}\text { O controle de } \\
\text { atualização de } \\
\text { procedimentos, } \\
\text { instruções e } \\
\text { registros é feito } \\
\text { de forma } \\
\text { separada }\end{array}$ & $\begin{array}{l}\text { O controle de } \\
\text { atualização de } \\
\text { procedimentos, } \\
\text { instruções e } \\
\text { registros é feito } \\
\text { de forma separada } \\
\text { e alinhada }\end{array}$ & $\begin{array}{l}\text { O controle de } \\
\text { atualização de } \\
\text { procedimentos, } \\
\text { instruções e } \\
\text { registros é } \\
\text { integrado }\end{array}$ & $\begin{array}{l}\text { O controle de } \\
\text { atualização de } \\
\text { procedimentos, } \\
\text { instruções e } \\
\text { registros é } \\
\text { integrado. Há } \\
\text { indicadores de } \\
\text { acompanhamento } \\
\text { desses controles }\end{array}$ & $\begin{array}{l}\text { O controle de } \\
\text { atualização de } \\
\text { procedimentos, } \\
\text { instruções e } \\
\text { registros é } \\
\text { integrado. Há } \\
\text { indicadores de } \\
\text { acompanhamento } \\
\text { desses controles } \\
\text { que são revisados } \\
\text { constantemente }\end{array}$ \\
\hline \multicolumn{6}{|c|}{ IMPLEMENTAÇÃ̃O / EXECUÇÃO } \\
\hline 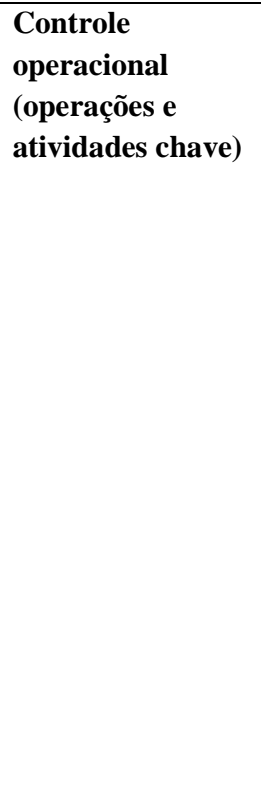 & $\begin{array}{l}\text { Na hora de } \\
\text { identificar as } \\
\text { operações e } \\
\text { atividades chave } \\
\text { para cada um dos } \\
\text { sistemas de } \\
\text { gestão, isso é } \\
\text { feito de forma } \\
\text { separada }\end{array}$ & $\begin{array}{l}\text { Na hora de } \\
\text { identificar as } \\
\text { operações e } \\
\text { atividades chave } \\
\text { para cada um dos } \\
\text { sistemas de } \\
\text { gestão, isso é feito } \\
\text { de forma separada } \\
\text { e alinhada }\end{array}$ & $\begin{array}{l}\text { Na hora de } \\
\text { identificar as } \\
\text { operações e } \\
\text { atividades chave } \\
\text { para cada um dos } \\
\text { sistemas de } \\
\text { gestão, isso é feito } \\
\text { de forma conjunta }\end{array}$ & $\begin{array}{l}\text { Na hora de } \\
\text { identificar as } \\
\text { operações e } \\
\text { atividades chave } \\
\text { para cada um dos } \\
\text { sistemas de } \\
\text { gestão, isso é feito } \\
\text { de forma conjunta } \\
\text { e indicadores são } \\
\text { utilizados para } \\
\text { verificar quais } \\
\text { operações e } \\
\text { atividades são } \\
\text { importantes }\end{array}$ & $\begin{array}{l}\text { Na hora de } \\
\text { identificar as } \\
\text { operações e } \\
\text { atividades chave } \\
\text { para cada um dos } \\
\text { sistemas de } \\
\text { gestão, isso é feito } \\
\text { de forma conjunta } \\
\text { e indicadores são } \\
\text { utilizados para } \\
\text { verificar quais } \\
\text { operações e } \\
\text { atividades são } \\
\text { importantes. } \\
\text { Revisões são } \\
\text { feitas visando um } \\
\text { maior } \\
\text { desempenho } \\
\text { operacional }\end{array}$ \\
\hline $\begin{array}{l}\text { Funções, } \\
\text { responsabilidades } \\
\text { e autoridades }\end{array}$ & $\begin{array}{l}\text { As funções, } \\
\text { responsabilidades } \\
\text { e autoridades são } \\
\text { estabelecidades } \\
\text { separadamente } \\
\text { para cada uma } \\
\text { das normas }\end{array}$ & $\begin{array}{l}\text { As funções, } \\
\text { responsabilidades } \\
\text { e autoridades são } \\
\text { estabelecidades } \\
\text { separadamente } \\
\text { para cada uma das } \\
\text { normas, porém } \\
\text { procurando um } \\
\text { alinhamento entre } \\
\text { elas }\end{array}$ & $\begin{array}{l}\text { As funções, } \\
\text { responsabilidades } \\
\text { e autoridades são } \\
\text { estabelecidades } \\
\text { em conjunto } \\
\text { levando em } \\
\text { consideração } \\
\text { todas as normas }\end{array}$ & $\begin{array}{l}\text { As funções, } \\
\text { responsabilidades } \\
\text { e autoridades são } \\
\text { estabelecidades } \\
\text { em conjunto } \\
\text { levando em } \\
\text { consideração } \\
\text { todas as normas, } \\
\text { sendo que estão } \\
\text { alinhadas com o } \\
\text { planejamento } \\
\text { estratégico }\end{array}$ & $\begin{array}{l}\text { As funções, } \\
\text { responsabilidades } \\
\text { e autoridades são } \\
\text { estabelecidades } \\
\text { em conjunto } \\
\text { levando em } \\
\text { consideração } \\
\text { todas as normas, } \\
\text { sendo que estão } \\
\text { alinhadas com o } \\
\text { planejamento } \\
\text { estratégico e são } \\
\text { revisadas } \\
\text { constantemente } \\
\text { para se adaptar as } \\
\text { mudanças }\end{array}$ \\
\hline
\end{tabular}

Figura 14 - Ferramenta de Avaliação do Grau de Maturidade em SGI (continuação) 


\begin{tabular}{|c|c|c|c|c|c|}
\hline $\begin{array}{l}\text { Equipe que } \\
\text { realiza a } \\
\text { implantação }\end{array}$ & $\begin{array}{l}\text { A implantação é } \\
\text { feita } \\
\text { separadamente, } \\
\text { ou seja, cada } \\
\text { norma conta com } \\
\text { equipe própria } \\
\text { para fazer a } \\
\text { implantação }\end{array}$ & $\begin{array}{l}\text { A implantação } \\
\text { das normas é feita } \\
\text { por uma única } \\
\text { equipe que possui } \\
\text { a visão das } \\
\text { normas em } \\
\text { separado }\end{array}$ & $\begin{array}{l}\text { A implantação } \\
\text { das normas é feita } \\
\text { por uma única } \\
\text { equipe que } \\
\text { trabalha as } \\
\text { normas de forma } \\
\text { integrada }\end{array}$ & $\begin{array}{l}\text { A implantação do } \\
\text { SGI é feita por } \\
\text { uma única equipe. } \\
\text { Há indicadores de } \\
\text { acompanhamento } \\
\text { do desempenho da } \\
\text { equipe que realiza } \\
\text { a implantação }\end{array}$ & $\begin{array}{l}\text { A implantação do } \\
\text { SGI é feita por } \\
\text { uma única equipe. } \\
\text { Há indicadores de } \\
\text { acompanhamento } \\
\text { do desempenho da } \\
\text { equipe que realiza } \\
\text { a implantação e os } \\
\text { mesmos são } \\
\text { revisados para } \\
\text { atender os } \\
\text { objetivos }\end{array}$ \\
\hline $\begin{array}{l}\text { Recursos } \\
\text { (humanos, } \\
\text { infra-estrutura, } \\
\text { financeiro) }\end{array}$ & $\begin{array}{l}\text { Os recursos nem } \\
\text { sempre são } \\
\text { suficientes e são } \\
\text { divididos de } \\
\text { forma desigual } \\
\text { entre as normas }\end{array}$ & $\begin{array}{l}\text { Os recursos são } \\
\text { disponibilizados } \\
\text { de forma } \\
\text { suficiente e são } \\
\text { divididos de } \\
\text { forma desigual } \\
\text { entre as normas, } \\
\text { ou seja, algumas } \\
\text { normas recebem } \\
\text { mais recursos que } \\
\text { outras }\end{array}$ & $\begin{array}{l}\text { Há recursos } \\
\text { suficientes e são } \\
\text { disponibilizados } \\
\text { para o SGI, ou } \\
\text { seja, os recursos } \\
\text { são distribuídos } \\
\text { considerando a } \\
\text { integração }\end{array}$ & $\begin{array}{l}\text { Há recursos } \\
\text { suficientes e são } \\
\text { disponibilizados } \\
\text { para o SGI, ou } \\
\text { seja, os recursos } \\
\text { são distribuídos } \\
\text { considerando a } \\
\text { integração. São } \\
\text { utilizados } \\
\text { indicadores para } \\
\text { acompanhamento } \\
\text { da utilização dos } \\
\text { recursos }\end{array}$ & $\begin{array}{l}\text { Há recursos } \\
\text { suficientes e são } \\
\text { disponibilizados } \\
\text { para o SGI, ou } \\
\text { seja, os recursos } \\
\text { são distribuídos } \\
\text { considerando a } \\
\text { integração. São } \\
\text { utilizados } \\
\text { indicadores para } \\
\text { acompanhamento } \\
\text { da utilização dos } \\
\text { recursos e os } \\
\text { mesmos são } \\
\text { monitorados e } \\
\text { quando necessários } \\
\text { revisados }\end{array}$ \\
\hline
\end{tabular}

Figura 14 - Ferramenta de Avaliação do Grau de Maturidade em SGI (continuação) 


\begin{tabular}{|c|c|c|c|c|c|}
\hline Treinamentos & $\begin{array}{l}\text { Os } \\
\text { treinamentos } \\
\text { são feitos } \\
\text { procurando } \\
\text { contemplar as } \\
\text { necessidades } \\
\text { das normas de } \\
\text { forma } \\
\text { independente. } \\
\text { Os registros } \\
\text { são mantidos } \\
\text { em separado }\end{array}$ & $\begin{array}{l}\text { Alguns } \\
\text { treinamentos são } \\
\text { disponibilizados } \\
\text { tendo em vista a } \\
\text { preocupação com } \\
\text { mais de uma } \\
\text { norma e os } \\
\text { registros podem } \\
\text { ou não ser } \\
\text { mantidos em } \\
\text { conjunto }\end{array}$ & $\begin{array}{l}\text { Os treinamentos } \\
\text { são } \\
\text { disponibilizados } \\
\text { procurando levar } \\
\text { em consideração o } \\
\text { maior número de } \\
\text { normas possível ou } \\
\text { que possam } \\
\text { impactar no assunto } \\
\text { abordado no } \\
\text { treinamento. Os } \\
\text { registros do } \\
\text { treinamento são } \\
\text { gerenciados de } \\
\text { forma integrada }\end{array}$ & $\begin{array}{l}\text { Os treinamentos } \\
\text { são } \\
\text { disponibilizados } \\
\text { procurando levar } \\
\text { em consideração o } \\
\text { maior número de } \\
\text { normas possíveis } \\
\text { ou que possam } \\
\text { impactar no } \\
\text { assunto abordado } \\
\text { no treinamento. } \\
\text { Os registros do } \\
\text { treinamento são } \\
\text { gerenciados de } \\
\text { forma integrada e } \\
\text { há indicadores } \\
\text { que ajudam a ver } \\
\text { quão efetivos são } \\
\text { os treinamentos }\end{array}$ & $\begin{array}{l}\text { Os treinamentos } \\
\text { são } \\
\text { disponibilizados } \\
\text { procurando levar } \\
\text { em consideração o } \\
\text { maior número de } \\
\text { normas possíveis } \\
\text { ou que possam } \\
\text { impactar no assunto } \\
\text { abordado no } \\
\text { treinamento. Os } \\
\text { registros do } \\
\text { treinamento são } \\
\text { gerenciados de } \\
\text { forma integrada e } \\
\text { há indicadores que } \\
\text { ajudam a ver quão } \\
\text { efetivos são os } \\
\text { treinamentos. Os } \\
\text { treinamentos são } \\
\text { revisados } \\
\text { constantemente de } \\
\text { acordo com os } \\
\text { resultados de suas } \\
\text { avaliações e } \\
\text { efetividade } \\
\text { (eficiência e } \\
\text { eficácia) }\end{array}$ \\
\hline Comunicação & $\begin{array}{l}\text { Cada norma } \\
\text { tem um } \\
\text { responsável } \\
\text { por sua } \\
\text { comunicação e } \\
\text { isso ocorre de } \\
\text { forma } \\
\text { independente }\end{array}$ & $\begin{array}{l}\text { Cada norma tem } \\
\text { um responsável } \\
\text { por sua } \\
\text { comunicação e há } \\
\text { um alinhamento } \\
\text { entre essa } \\
\text { comunicação }\end{array}$ & $\begin{array}{l}\text { Há uma estrutura } \\
\text { única que cuida de } \\
\text { todo processo de } \\
\text { comunicação das } \\
\text { normas e as } \\
\text { mesmas são } \\
\text { consideradas de } \\
\text { forma integrada }\end{array}$ & $\begin{array}{l}\text { Há uma estrutura } \\
\text { única que cuida } \\
\text { de todo processo } \\
\text { de comunicação } \\
\text { das normas e as } \\
\text { normas são } \\
\text { consideradas de } \\
\text { forma integrada. } \\
\text { Indicadores são } \\
\text { usados para medir } \\
\text { a efetividade } \\
\text { dessa } \\
\text { comunicação }\end{array}$ & $\begin{array}{l}\text { Há uma estrutura } \\
\text { única que cuida de } \\
\text { todo processo de } \\
\text { comunicação das } \\
\text { normas e as normas } \\
\text { são consideradas de } \\
\text { forma integrada. } \\
\text { Indicadores são } \\
\text { usados para medir a } \\
\text { efetividade dessa } \\
\text { comunicação, os } \\
\text { quais são revisados } \\
\text { constantemente de } \\
\text { forma a } \\
\text { proporcionar uma } \\
\text { melhor } \\
\text { comunicação }\end{array}$ \\
\hline
\end{tabular}

Figura 14 - Ferramenta de Avaliação do Grau de Maturidade em SGI (continuação) 


\begin{tabular}{|c|c|c|c|c|c|}
\hline \multicolumn{6}{|c|}{ VERIFICAÇÃO / AÇÃO } \\
\hline $\begin{array}{l}\text { Auditoria } \\
\text { interna }\end{array}$ & $\begin{array}{l}\text { As auditorias } \\
\text { internas são feitas } \\
\text { por equipes } \\
\text { diferentes, em } \\
\text { períodos } \\
\text { diferentes e geram } \\
\text { relatórios } \\
\text { separados }\end{array}$ & $\begin{array}{l}\text { As auditorias } \\
\text { internas são feitas } \\
\text { por uma única } \\
\text { equipe e ao } \\
\text { mesmo tempo, } \\
\text { gerando relatórios } \\
\text { separados }\end{array}$ & $\begin{array}{l}\text { As auditorias } \\
\text { internas são feitas } \\
\text { por uma única } \\
\text { equipe e ao } \\
\text { mesmo tempo, } \\
\text { gerando um único } \\
\text { relatório }\end{array}$ & $\begin{array}{l}\text { As auditorias } \\
\text { internas são feitas } \\
\text { por uma única } \\
\text { equipe e ao } \\
\text { mesmo tempo, } \\
\text { gerando um único } \\
\text { relatório. } \\
\text { Indicadores são } \\
\text { estabelecidos para } \\
\text { avaliar a evolução } \\
\text { dos sistemas }\end{array}$ & $\begin{array}{l}\text { As auditorias } \\
\text { internas são feitas } \\
\text { por uma única } \\
\text { equipe e ao } \\
\text { mesmo tempo, } \\
\text { gerando um único } \\
\text { relatório. } \\
\text { Indicadores são } \\
\text { estabelecidos para } \\
\text { avaliar a evolução } \\
\text { dos sistemas e } \\
\text { quando necessário } \\
\text { são definidos } \\
\text { ações de melhoria }\end{array}$ \\
\hline $\begin{array}{l}\text { Auditoria } \\
\text { externa (do } \\
\text { órgão } \\
\text { certificador) }\end{array}$ & $\begin{array}{l}\text { A auditoria } \\
\text { externa é feita por } \\
\text { auditores } \\
\text { diferentes, em } \\
\text { períodos } \\
\text { diferentes e geram } \\
\text { relatórios } \\
\text { separados }\end{array}$ & $\begin{array}{l}\text { A auditoria } \\
\text { externa é feita por } \\
\text { um único auditor, } \\
\text { o qual audita } \\
\text { todas as normas } \\
\text { integradas, } \\
\text { gerando relatórios } \\
\text { separados }\end{array}$ & $\begin{array}{l}\text { A auditoria } \\
\text { externa é feita por } \\
\text { um único auditor, } \\
\text { o qual audita } \\
\text { todas as normas } \\
\text { integradas, } \\
\text { gerando um único } \\
\text { relatório }\end{array}$ & $\begin{array}{l}\text { A auditoria } \\
\text { externa é feita por } \\
\text { um único auditor, } \\
\text { o qual audita } \\
\text { todas as normas } \\
\text { integradas, } \\
\text { gerando um único } \\
\text { relatório. } \\
\text { Indicadores são } \\
\text { estabelecidos para } \\
\text { avaliar a evolução } \\
\text { dos sistemas }\end{array}$ & $\begin{array}{l}\text { A auditoria } \\
\text { externa é feita por } \\
\text { um único auditor, } \\
\text { o qual audita } \\
\text { todas as normas } \\
\text { integradas, } \\
\text { gerando um único } \\
\text { relatório. } \\
\text { Indicadores são } \\
\text { estabelecidos para } \\
\text { avaliar a evolução } \\
\text { dos sistemas e } \\
\text { quando necessário } \\
\text { são definidos } \\
\text { ações de melhoria }\end{array}$ \\
\hline
\end{tabular}

Figura 14 - Ferramenta de Avaliação do Grau de Maturidade em SGI (continuação) 


\begin{tabular}{|c|c|c|c|c|c|}
\hline $\begin{array}{l}\text { Não } \\
\text { conformidades, } \\
\text { ações corretivas e } \\
\text { preventivas }\end{array}$ & $\begin{array}{l}\text { As não } \\
\text { conformidades, } \\
\text { ações corretivas e } \\
\text { preventivas são } \\
\text { tratadas de forma } \\
\text { totalmente } \\
\text { separadas entre as } \\
\text { normas }\end{array}$ & $\begin{array}{l}\text { Alguns aspectos } \\
\text { relacionados a } \\
\text { não } \\
\text { conformidades, } \\
\text { ações corretivas e } \\
\text { preventivas são } \\
\text { tratadas de forma } \\
\text { integrada }\end{array}$ & $\begin{array}{l}\text { As não } \\
\text { conformidades, } \\
\text { ações corretivas e } \\
\text { preventivas são } \\
\text { tratadas de forma } \\
\text { integrada }\end{array}$ & $\begin{array}{l}\text { As não } \\
\text { conformidades, } \\
\text { ações corretivas e } \\
\text { preventivas são } \\
\text { tratadas de forma } \\
\text { integradas. } \\
\text { Indicadores são } \\
\text { implantados para } \\
\text { avaliar e } \\
\text { acompanhar a } \\
\text { evolução das não } \\
\text { conformidades, } \\
\text { ações corretivas e } \\
\text { preventivas }\end{array}$ & $\begin{array}{l}\text { As não } \\
\text { conformidades, } \\
\text { ações corretivas e } \\
\text { preventivas são } \\
\text { tratadas de forma } \\
\text { integradas. } \\
\text { Indicadores são } \\
\text { implantados para } \\
\text { avaliar e } \\
\text { acompanhar a } \\
\text { evolução das não } \\
\text { conformidades, } \\
\text { ações corretivas e } \\
\text { preventivas, } \\
\text { sendo que os } \\
\text { resultados dos } \\
\text { indicadores são } \\
\text { revisados e } \\
\text { melhorados }\end{array}$ \\
\hline $\begin{array}{l}\text { Análise crítica da } \\
\text { administração }\end{array}$ & $\begin{array}{l}\text { A análise é feita } \\
\text { de forma } \\
\text { totalmente } \\
\text { separada }\end{array}$ & $\begin{array}{l}\text { A análise é feita } \\
\text { de forma } \\
\text { separada, } \\
\text { buscando o } \\
\text { alinhamento entre } \\
\text { as normas }\end{array}$ & $\begin{array}{l}\text { A análise é feita } \\
\text { de forma conjunta } \\
\text { e integrada }\end{array}$ & $\begin{array}{l}\text { A análise é feita } \\
\text { de forma conjunta } \\
\text { e integrada, } \\
\text { estabelecendo } \\
\text { metas e } \\
\text { indicadores que } \\
\text { avaliam o } \\
\text { desempenho dos } \\
\text { sistemas }\end{array}$ & $\begin{array}{l}\text { A análise é feita } \\
\text { de forma conjunta } \\
\text { e integrada, } \\
\text { estabelecendo } \\
\text { metas e } \\
\text { indicadores que } \\
\text { avaliam o } \\
\text { desempenho dos } \\
\text { sistemas e quando } \\
\text { aplicável, ações } \\
\text { são } \\
\text { implementadas } \\
\text { para melhorar o } \\
\text { desempenho }\end{array}$ \\
\hline
\end{tabular}

Figura 14 - Ferramenta de Avaliação do Grau de Maturidade em SGI (final)

Para se utilizar a ferramenta, basta assinalar qual das 5 opções em cada uma das linhas se adequa melhor a realidade da organização em que se trabalha. Após responder as 21 questões, será necessário fazer uma análise geral da situação, seguida de um plano de ação para se atacar os pontos que se encontram nos níveis menores de forma que eles possam atingir níveis maiores de maturidade.

A seguir, é apresentado um exemplo ilustrativo de uma organização fictícia. A Tabela 10 ajudará a compreender melhor como é feita a pontuação do nível de maturidade e a Figura 15 mostrará como é dado o resultado final.

A coluna Pontuação da Tabela 10 apresenta o número de questões que o respondente assinalou para um determinado nível de maturidade. 
Tabela 10 - Forma de pontuação da ferramenta

\begin{tabular}{|c|c|c|c|}
\hline Nível & Pontuação & Somatória da Pontuação & $\%$ \\
\hline 1 & 7 & 21 & 100 \\
\hline 2 & 5 & 14 & 67 \\
\hline 3 & 5 & 9 & 43 \\
\hline 4 & 3 & 4 & 19 \\
\hline 5 & 1 & 1 & 5 \\
\hline
\end{tabular}

A somatória apresentada na Tabela 10 evidencia que a organização, antes de atingir o nível 3, completou os requisitos dos níveis 1 e 2, e assim por diante. Ou seja, a somatória nada mais é do que a pontuação do nível posterior, somada à pontuação do nível em que se encontra. No caso do nível 2, o resultado 14 diz respeito à somatória do nível 3 que é 9, mais a pontuação do nível 2 que é 5 . A coluna \% representa a aderência àquele nível, deste modo conclui-se que a aderência ao nível 4 e 5 é baixa. Por meio da tabela 10, nota-se que a organização representada se encaixaria no nível 2, pois sua taxa de aderência ao mesmo é de $67 \%$. Um questionamento poderia ser levantado acerca dos motivos de não se considerar o nível 1, uma vez que o mesmo representa $100 \%$. Entretanto, é importante no momento da avaliação utilizar o primeiro nível que se encontra abaixo de $100 \%$, pois é ele que deverá ser priorizado na melhoria. A Figura 15 faz uma representação visual do percentual de aderência da Tabela 10.

\begin{tabular}{|c|c|c|c|c|c|}
\cline { 2 - 6 } \multicolumn{1}{c|}{} & \multicolumn{5}{c|}{ Percentual de Aderência } \\
\hline Nivel & $20 \%$ & $40 \%$ & $60 \%$ & $80 \%$ & $100 \%$ \\
\hline 1 & & & & & \\
\hline 2 & & & & & \\
\hline 3 & & & & & \\
\hline 4 & & & & & \\
\hline 5 & & & & & \\
\hline
\end{tabular}

Figura 15 - Representação do nível de maturidade

De acordo com a Figura 15, é possível notar que, pelo percentual de aderência, a organização representada estaria no nível 2 de maturidade em termos de integração dos seus sistemas de gestão. 


\section{Conclusões}

Este trabalho teve como objetivo elaborar uma ferramenta de avaliação de maturidade que possibilitasse avaliar o grau de integração do SGI e com isso trouxesse um retorno tanto do aspecto acadêmico como prático. Essa preocupação com o aspecto prático é ressaltada por Karlsson (2009) onde relata que as universidades estão sendo cobradas por atividades e pesquisas que envolvem o crescimento econômico e tenham aplicabilidade nos negócios. Tendo como preocupação a questão da aplicabilidade de um lado e a falta de estudos com esse enfoque revelado pela RBS de outro, resolveu-se traçar o objetivo exposto acima.

A utilização de modelos de maturidade por diversas áreas tem crescido ao longo dos anos conforme revela a pesquisa de Wendler (2012), sendo que de 2003 até 2009 o número de publicações saltou de 15 para 34. Os modelos de maturidade são usados como ferramentas de melhoria de processo, descrevendo o processo em patamares de sofisticação, objetivando orientar o esforço de melhoria (CRISTOFARI JÚNIOR; PAULA; FOGLIATTO, 2010). A questão de pesquisa que surge é: "Como avaliar o nível de maturidade de um Sistema de Gestão Integrado?".

Para a realização deste trabalho, primeiramente fez-se uma revisão bibliográfica exploratória e uma RBS sobre SGI, seguida de uma revisão bibliográfica exploratória sobre Modelo de Maturidade. A Revisão Bibliográfica Sistemática (RBS) feita neste trabalho revelou um aumento considerável de estudos referentes a SGI passando de 4 publicações em 2002 para 13 publicações em 2012. Ao mesmo tempo em que se observa esse aumento, notase a falta de um modelo de maturidade para avaliar o quão integrados estão esses sistemas de gestão. A integração é importante pois através dela há uma diminuição do número de documentos, redução de custos, melhora na comunicação, diminuição do número de auditorias, melhora na tomada de decisão e melhor utlização de recuros (LÓPEZ-FRESNO, 2010; SALOMONE, 2008; VITORELI, 2011; ZUTSHI; SOHAL, 2005). Além destes benefícios existem muitos outros conforme levantado nesta disertação. A organização que opta por trabalhar os sistemas de gestão de forma separada tem dificuldade em assegurar o alinhamento entre os sistemas e acaba tendo trabalho duplicado.

Após as revisões, foi elaborada uma ferramenta de avaliação do grau de maturidade voltado para SGI. A ferramenta foi avaliada por especialistas acadêmicos e por profissionais que trabalham diretamente com a integração de sistemas de gestão. Com base nas sugestões dadas pelos especialistas, foi desenvolvida a versão final apresentada neste trabalho. 
A ferramenta criada teve como grande influência o CMMI e o modelo apresentado na ISO 9004, o qual é voltado para avaliação de maturidade em gestão da qualidade. No total são 21 pontos avaliados, os quais estão divididos em 4 grandes áreas conforme demonstrado na Figura 16. Para elaboração de cada um dos 21 pontos foi levado em consideração os itens em comum das normas ISO 9001, ISO 14001, OHSAS 18001 e NBR 16001. A ferramenta conta com dois eixos, na horizontal, mais precisamente na primeira linha, são apresentados os níveis de maturidade e na vertical, especificamente na primeira coluna, estão as atividades e elementos-chave importantes para a integração.

\begin{tabular}{|c|l|lrl|}
\hline \# Questões & \multicolumn{1}{|c|}{ Área } & \multicolumn{3}{|c|}{ Pontos Abordados } \\
\hline 4 & Política & $\begin{array}{l}\text { existência de política integrada, participação da alta administração, } \\
\text { atualização e documentação, divulgação }\end{array}$ & \\
\hline 6 & Planejamento & $\begin{array}{l}\text { elaboração, equipe, objetivos e } \\
\text { procedimentos/instruções/registros, }\end{array}$ & metas, manual, \\
procedimentos/instruções/registros, & de \\
\hline 7 & $\begin{array}{l}\text { Implementação/ } \\
\text { Excecução }\end{array}$ & $\begin{array}{l}\text { controle operacional, funções/responsabilidades/autoridades, } \\
\text { equipe, recursos, treinamentos, comunicação, monitoramento }\end{array}$ \\
\hline 4 & $\begin{array}{l}\text { Verificação/ } \\
\text { Ação }\end{array}$ & $\begin{array}{l}\text { auditoria interna, auditoria externa, não conformidades/ações } \\
\text { corretivas e preventivas, análise da administração }\end{array}$ \\
\hline
\end{tabular}

Figura 16 - Número de Questões da Ferramenta de Avaliação do Grau de Maturidade em SGI dividida por área e por pontos abordados

A ferramenta apresentada ajudará as empresas que possuem mais de um sistema de gestão implantado a fazer uma autoanálise de como se encontra quanto a integração, bem como poderá servir de base para que a mesma, a partir do resultado da ferramenta, trace um plano de ação para que se possa atingir um maior nível de integração.

Além do desenvolvimento da ferramenta de avaliação do grau de maturidade, esta dissertação apresentou uma ampla revisão sobre SGI e um resumo de todos os trabalhos pesquisados pode ser encontrado na Figura 17 do apêndice A. É de grande importância a pesquisa sobre a integração de sistemas de gestão, pois conforme demonstra o Gráfico 5 apresentado no tópico 2.2.4, é crescente o número de publicações sobre o tema. Um dos 
motivos para esse aumento pode ser atribuído ao fato do número crescente de normas e de empresas que as adotam, o que faz com que a sua utilização em separado provoque redundâncias e confusões.

Os objetivos traçados no início do trabalho foram alcançados. Realizou-se a RBS sobre SGI onde foi possível perceber que há relativamente pouca pesquisa sobre o assunto embora o número de publicações tenha crescido ao longo dos últimos anos. Também foi possível perceber que a maior parte das pesquisas sobre SGI estão relacionadas a modelos para integração dos sistemas de gestão, bem como a levantamentos sobre benefícios, dificuldades e motivações para a integração. O país onde mais se realizou publicações sobre o assunto foi a Espanha e os periódicos que mais publicaram artigos relacionados a SGI foram o "Journal of Cleaner Production" e "The TQM Journal". Essas questões fazem parte dos objetivos secundários estabelecidos. Outro objetivo secundário alcançado foi um levantamento sobre os principais modelos de maturidade, os quais são o CMMI e o OPM3. Porém, outros modelos também foram pesquisados. E por fim, o objetivo principal que era elaborar uma ferramenta para avaliação do grau de maturidade em SGI foi concluida e pode ser encontrada na Figura 14 que se encontra no Capítulo 4.

Como sugestão de trabalho futuro, sugere-se a aplicação da ferramenta proposta em empresas com o intuito de avaliar o nível de maturidade e não mais o instrumento em si. Outra sugestão é a aplicação do mesmo em formato survey, onde será possível detectar como as empresas em média se encontram nesse quesito.

Como possível limitação do trabalho pode-se citar o fato de não tê-lo aplicado em empresas com o propósito de avaliá-las, mas isso poderá ser feito em pesquisas posteriores dando seguimento a essa dissertação. 


\section{Referências Bibliográficas}

AL-DARRAB, I. A.; GULZAR, W. A.; ALI, K. S. Status of implementation of safety , quality and environmental management systems in Saudi Arabian industries. Total Quality Management \& Business Excellence, v. 24, n. 3, p. 336-354, 2013.

ALMEIDA, A. S. L. DE et al. Proposição de um modelo de gestão do conhecimento para empresas com Sistemas Integrados de GestãoENEGEP. Anais...2007

ARIFIN, K. et al. Implementation of Integrated Management System in Malaysia: The Level of Organization' $\mathrm{s}$ Understanding and Awareness. European Journal of Scientific Research, v. 31, n. 2, p. 188-195, 2009.

ASIF, M. et al. An examination of strategies employed for the integration of management systems. The TQM Journal, v. 22, n. 6, p. 648-669, 2010.

ASSOCIAÇÃO BRASILEIRA DE NORMAS TÉCNICAS. ABNT NBR ISO 14001:2004. Rio de Janeiro: Associação Brasileira de Normas Técnicas, 2004. p. 27

ASSOCIAÇÃO BRASILEIRA DE NORMAS TÉCNICAS. ABNT NBR ISO 9001:2008. Rio de Janeiro: Associação Brasileira de Normas Técnicas, 2008. p. 28

ASSOCIAÇÃO BRASILEIRA DE NORMAS TÉCNICAS. ABNT NBR ISO 9004:2010. Rio de Janeiro: Associação Brasileira de Normas Técnicas, 2010. p. 47

ASSOCIAÇÃO BRASILEIRA DE NORMAS TÉCNICAS. ABNT NBR 16001:2012. Rio de Janeiro: Associação Brasileira de Normas Técnicas, 2012. p. 48

AZADEH, A.; FARMAND, A. H.; SHARAHI, Z. J. Performance assessment and optimization of HSE management systems with human error and ambiguity by an integrated fuzzy multivariate approach in a large conventional power plant manufacturer. Journal of Loss Prevention in the Process Industries, v. 25, n. 3, p. 594-603, maio 2012.

BALDRIGE PERFORMANCE EXCELLENCE PROGRAM. Criteria for Performance Excellence: 2013-2014. Gaithersburg: National Institute of Standards and Technology, 2013. p. 54

BAMBER, C. J.; SHARP, J. M.; CASTKA, P. Third party assessment: the role of the maintenance function in an integrated management system. Journal of Quality in Maintenance Engineering, v. 10, n. 1, p. 26-36, 2004.

BECKMERHAGEN, I. A. et al. Integration of management systems: focus on safety in the nuclear industry. International Journal of Quality \& Reliability Management, v. 20, n. 2, p. 210-228, 2003. 
BERNARDO, M. et al. How integrated are environmental, quality and other standardized management systems? An empirical study. Journal of Cleaner Production, v. 17, n. 8, p. 742-750, maio 2009.

BERNARDO, M. et al. An empirical study on the integration of management system audits. Journal of Cleaner Production, v. 18, n. 5, p. 486-495, mar. 2010.

BERNARDO, M. et al. Relationships between the integration of audits and management systems: An empirical study. The TQM Journal, v. 23, n. 6, p. 659-672, 2011.

BERNARDO, M. et al. Integration of standardized management systems: does the implementation order matter? International Journal of Operations \& Production Management, v. 32, n. 3, p. 291-307, 2012a.

BERNARDO, M. et al. Do integration difficulties influence management system integration levels? Journal of Cleaner Production, v. 21, n. 1, p. 23-33, jan. 2012b.

BOIRAL, O. Managing with ISO Systems: Lessons from Practice. Long Range Planning, v. 44, n. 3, p. 197-220, jun. 2011.

BORSARI, R. Avaliação dos Impactos da Transição da Norma QS9000 para ISO / TS 16949 e suas Consequências sobre o Sistema de Gestão da Qualidade. [s.l.] Unicamp, 2008.

BOTTA, S.; COMOGLIO, C.; PETROSILLO, I. Implementing the environmental and social policies of a municipality through an integrated management system: theoretical framework and case study. Journal of Environmental Planning and Management, n. December, p. 123, 19 nov. 2012.

BRENDLER, E.; BRANDLI, L. L. Integração do sistema de gestão ambiental no sistema de gestão de qualidade em uma indústria de confecções. Gestão \& Produção, v. 18, n. 1, p. 2740, 2011.

BRITISH STANDARDS INSTITUTION. OHSAS 18001:2007. 2. ed. London: OHSAS Project Group, 2007. p. 22

BRUIN, T. DE et al. Understanding the Main Phases of Developing a Maturity Assessment Model16th Australasian Conference on Information Systems. Anais...2005

CAMPOS, C. A. DE O.; MEDEIROS, D. D. DE. Um modelo de integração de sistemas de gestão. Revista Produção, v. 19, p. 70-86, 2009.

CARNEGIE MELLON INSTITUTE. CMMI ® para Desenvolvimento - Versão 1.2. Pittsburgh: [s.n.]. Disponível em: <http://www.sei.cmu.edu/library/assets/whitepapers/cmmidev_1-2_portuguese.pdf>.

CARPINETTI; MIGUEL; GEROLAMO. Gestão da Qualidade ISO 9001:2008 : Princípios e Requisitos. 4. ed. São Paulo: Atlas, 2011. p. 128 
CASADESÚS, M.; KARAPETROVIC, S.; HERAS, I. Synergies in standardized management systems: some empirical evidence. The TQM Journal, v. 23, n. 1, p. 73-86, 2011.

CHRISSIS, M. B.; KONRAD, M.; SHRUM, S. CMMI (Capability Maturity Model Integration): Guidelines for Process Integration and Product Improvement. Boston: Addison-Wesley, 2003. p. 663

CONFORTO, E. C.; AMARAL, D. C.; SILVA, S. L. DA. Roteiro para revisão bibliográfica sistemática : aplicação no desenvolvimento de produtos e gerenciamento de projetos $8^{\circ}$ Congresso Brasileiro de Gestão de Desenvolvimento de Produto. Anais...2011

CRISTOFARI JÚNIOR, C. A.; PAULA, I. C. DE; FOGLIATTO, F. S. Método de análise de maturidade e priorização de melhorias na gestão do Processo de Desenvolvimento de Produtos. Produção, v. 20, n. 3, p. 359-377, set. 2010.

CROSBY, P. B. Qualidade é Investimento: a arte de garantir a qualidade. 2. ed. Rio de Janeiro: José Olympio Editora, 1986. p. 327

CUENCA, L. et al. Structural elements of coordination mechanisms in collaborative planning processes and their assessment through maturity models: Application to a ceramic tile company. Computers in Industry, v. 64, n. 8, p. 898-911, out. 2013.

DE OLIVEIRA, O. J. Guidelines for the integration of certifiable management systems in industrial companies. Journal of Cleaner Production, v. 57, p. 124-133, out. 2013.

DOMINGUES, P. et al. Integrated OHS Management Systems: Is It The Final Frontier Regarding OHS?11th International Probabilistic Safety Assessment and Management Conference and the Annual European Safety and Reliability Conference 2012. Anais...2012

DROŻYNER, P. et al. Management Standardization Versus Quality of Working Life. Ergonomics and Health Aspects of Work with Computers, v. 6779, n. iv, p. 30-39, 2011.

FRASER, P.; MOULTRIE, J.; GREGORY, M. The use of maturity models / grids as a tool in assessing product development capabilityIEEE Institute of Electrical and Electronics Engineers. Anais...2002Disponível em: $<$ http://ieeexplore.ieee.org/stamp/stamp.jsp?tp=\&arnumber=1038431\&isnumb er $=22257 \& \operatorname{tag}=1>$

GANGOLELLS, M. et al. Model for Enhancing Integrated Identification , Assessment , and Operational Control of On-Site Environmental Impacts and Health and Safety Risks in Construction Firms. Journal of Construction Engineering and Management, v. 139, n. 2, p. 138-147, 2013.

GARENGO, P.; BIAZZO, S. Total Quality Management \& Business Excellence From ISO quality standards to an integrated management system : an implementation process in SME. Total Quality Management \& Business Excellence, v. 24, n. 3, p. 310-335, 2013. 
GRIFFITH, A.; BHUTTO, K. Improving environmental performance through integrated management systems (IMS) in the UK. Management of Environmental Quality: An International Journal, v. 19, n. 5, p. 565-578, 2008.

HELGESSON, Y. Y. L.; HÖST, M.; WEYNS, K. A review of methods for evaluation of maturity models for process improvement. Journal of Software Maintenance and Evolution: Research and Practice, p. 436-454, 2012.

HERAS-SAIZARBITORIA, I.; BOIRAL, O. ISO 9001 and ISO 14001: Towards a Research Agenda on Management System Standards*. International Journal of Management Reviews, 4 maio 2012.

HOLDSWORTH, R. Practical applications approach to design, development and implementation of an integrated management system. Journal of Hazardous Materials, v. 104, n. 1-3, p. 193-205, nov. 2003.

INMETRO. Programa Brasileiro de Certificação em Responsabilidade Social. Disponível em:

<http://www.inmetro.gov.br/qualidade/responsabilidade_social/programa_certificacao.asp>. Acesso em: 3 abr. 2013.

ISO. The Integrated Use of Management System Standards. 1. ed. Switzerland: ISO, 2008. p. 145

ISO. Benefits of International Standards. Disponível em: <http://www.iso.org/iso/home/standards/benefitsofstandards.htm>. Acesso em: 21 ago. $2012 \mathrm{a}$.

ISO. The ISO Survey of Management System Standard Certifications - 2011. Disponível em: <http://www.iso.org/iso/home/standards/certification/iso-survey.htm>. Acesso em: 28 dez. 2012b.

JØRGENSEN, T. H. Towards more sustainable management systems: through life cycle management and integration. Journal of Cleaner Production, v. 16, n. 10, p. 1071-1080, jul. 2008.

JØRGENSEN, T. H.; REMMEN, A.; MELLADO, M. D. Integrated management systems three different levels of integration. Journal of Cleaner Production, v. 14, n. 8, p. 713-722, jan. 2006.

KARAPETROVIC, S. Strategies for the integration of management systems and standards. The TQM Magazine, v. 14, n. 1, p. 61-67, 2002.

KARAPETROVIC, S.; CASADESÚS, M. Implementing environmental with other standardized management systems: Scope, sequence, time and integration. Journal of Cleaner Production, v. 17, n. 5, p. 533-540, mar. 2009. 
KARAPETROVIC, S.; WILLBORN, W. Integration of quality and environmental management systems. The TQM Magazine, v. 10, n. 3, p. 204-213, 1998.

KARLSSON, C. Researching Operations Management. 1. ed. New York: Routledge, 2009. p. 322

KHANNA, H. K.; LAROIYA, S. C.; SHARMA, D. D. Integrated management systems in Indian manufacturing organizations: Some key findings from an empirical study. The TQM Journal, v. 22, n. 6, p. 670-686, 2010.

KHOSHGOFTAR, M.; OSMAN, O. Comparison of Maturity ModelsIEEE International Conference on Computer Science and Information Technology - ICCSIT. Anais...2009Disponível em: $<$ http://ieeexplore.iee.org/stamp/stamp.jsp?tp=\&arnumber=5234402>

KOHLEGGER, M.; MAIER, R.; THALMANN, S. Understanding Maturity Models Results of a Structured Content AnalysisI-KNOW and I-SEMANTICS. Anais...Graz / Austria: 2009Disponível

em: <http://iwi.uibk.ac.at/download/downloads/Publikationen/KMM.pdf>

LEOPOULOS, V. et al. Integrated management systems: moving from function to organisation/decision view. The TQM Journal, v. 22, n. 6, p. 594-628, 2010.

LÓPEZ-FRESNO, P. Implementation of an integrated management system in an airline: a case study. The TQM Journal, v. 22, n. 6, p. 629-647, 2010.

MACKAU, D. SME integrated management system: a proposed experiences model. The TQM Magazine, v. 15, n. 1, p. 43-51, 2003.

MAIER, A. M.; MOULTRIE, J.; CLARKSON, P. J. Assessing Organizational Capabilities: Reviewing and Guiding the Development of Maturity Grids. IEEE Transactions on Engineering Management, v. 59, n. 1, p. 138-159, fev. 2012.

MAJSTOROVIĆ, V. D.; MARINKOVIĆ, V. The Development of Business Standardization and Integrated Management Systems. Journal of Medical Biochemistry, v. 30, n. 4, p. 334 345, 1 out. 2011.

MARIMBA, A.; FARINHA, J. T.; FERREIRA, L. International standards integration for ecologic asset management. Recent Advances in Energy \& Environment, n. 2, p. 54-61, 2010.

MARTINS, G. DE A.; THEÓPHILO, C. R. Metodologia da Investigação Científica para Ciências Sociais Aplicadas. $2^{\mathrm{a}}$. ed. São Paulo: Atlas, 2009. p. 264

MATURITY BY PROJECT CATEGORY MODEL. O Modelo Prado-MMgP. Disponível em: <http://www.maturityresearch.com/novosite/index_br.html>. Acesso em: 10 abr. 2013a.

MATURITY BY PROJECT CATEGORY MODEL. O Modelo Prado-MMGP V4. Disponível em: 
<http://www.maturityresearch.com/novosite/downloads/Modelo_PradoMMGP_V4_TextoDes critivo.pdf >. Acesso em: 10 abr. 2013 b.

MEŽINSKA, I.; LAPIN̦A, I.; MAZAIS, J. Integrated management systems towards sustainable and socially responsible organisation. Total Quality Management \& Business Excellence, p. 1-13, 23 set. 2013.

MIGUEL, P. A. C. et al. Metodologia de Pesquisa em Engenharia de Produção e Gestão de Operações. Rio de Janeiro: Elsevier, 2010. p. 226

MILLIMAN, J. et al. Pilot project results of an integrated security management system. Disaster Prevention and Management, v. 14, n. 1, p. 20-31, 2005.

NEE, A. Y. H. Implementation of Integrated Management System : Environmental and Safety Performance and Global Sustainability. ICEE 2009 - Proceeding 2009 3rd International Conference on Energy and Environment: Advancement Towards Global Sustainability, n. December, p. 232-241, 2009.

NETO, M. C. DA S. Pesquisa sobre Maturidade em Gerenciamento de Projetos Relatório Geral 2010. [s.l: s.n.]. Disponível em: <http://www.maturityresearch.com/novosite/2010/downloads/PesquisaMaturidade2010Rel.GeralCompleto-V4.pdf >.

NITU, L. D.; NITU, L.; SOLOMON, G. Model for Conformity Assessment of Integrated Management Systems. UPB Scientific Bulletin, v. 74, n. 2, p. 281-292, 2012.

NOURI, J. et al. Advantages of integrated management system in educational centers. Journal of Food, Agriculture \& Environment, v. 8, p. 1259-1264, 2010.

OFORI, G.; GANG, G.; BRI, C. Implementing environmental management systems in construction: lessons from quality systems. Building and Environment, v. 37, p. 13971407, 2002.

PAULK, M. C. A Taxonomy for Improvement FrameworksWorld Congr. Softw. Qual. Anais...Bethesda, MD: 2008

PHENG, L. S.; PONG, C. Y. Integrating ISO 9001 and OHSAS 18001 for Construction. Journal of Construction Engineering and Management, v. 129, n. 3, p. 338-347, 2003.

PIGOSSO, D. C. A. Ecodesign Maturity Model: a framework to support companies in the selection and implementation of ecodesign practices. [s.l.] USP, 2012.

PIGOSSO, D. C. A.; ROZENFELD, H.; MCALOONE, T. C. Ecodesign maturity model: a management framework to support ecodesign implementation into manufacturing companies. Journal of Cleaner Production, v. 59, p. 160-173, nov. 2013.

PMI. Organizational Project Management Maturity Model (OPM3). Pennsylvania: PMI, 2003. p. 179 
POJASEK, R. B. Is Your Integrated Management System Really Integrated ? Environmental Quality Management, v. 162, p. 89-97, 2006.

POPESCU, S. G.; TIFREA, D. I. Quality Management Systems' Maturity, a measure of the ISO 9001 implementation process. Quality - Access to Success, v. 12, n. 124, p. 12-18, 2011.

QUINTELLA, H. L. M. D. M.; ROCHA, H. M. Avaliação da maturidade do processo de desenvolvimento de veículos automotivos. Gestão \& Produção, v. 13, n. 2, p. 297-310, maio 2006.

REBELO, M.; SANTOS, G.; SILVA, R. Conception of a flexible integrator and lean model for integrated management systems. Total Quality Management \& Business Excellence, v. 0, n. 0, p. 1-19, 16 set. 2013.

REVISTA PROTEÇÃO. Anuário Brasileiro de Proteção 2012. Disponível em: <http://www.protecao.com.br/conteudo/anuario_2012/anuario_2012__parte_2/JyjgAA_JyyJJa>. Acesso em: 3 abr. 2013.

ROCHA, M.; SEARCY, C.; KARAPETROVIC, S. Integrating Sustainable Development into Existing Management Systems. Total Quality Management, v. 18, p. 83-92, 2007.

RÖNNINGER, S. Implementation of a Process-Oriented ISO 9000 and ISO 14000 Management System in a Chemical Manufacturing Site. CHIMIA International Journal for Chemistry, v. 56, n. 12, p. 714-720, 1 dez. 2002.

SALOMONE, R. Integrated management systems: experiences in Italian organizations. Journal of Cleaner Production, v. 16, n. 16, p. 1786-1806, nov. 2008.

SAMPAIO, P.; SARAIVA, P.; DOMINGUES, P. Management systems: integration or addition? International Journal of Quality \& Reliability Management, v. 29, n. 4, p. 402424, 2012.

SANTOS, G. et al. The main benefits associated with health and safety management systems certification in Portuguese small and medium enterprises post quality management system certification. Safety Science, v. 51, n. 1, p. 29-36, jan. 2013.

SANTOS, G.; MENDES, F.; BARBOSA, J. Certification and integration of management systems: the experience of Portuguese small and medium enterprises. Journal of Cleaner Production, v. 19, n. 17-18, p. 1965-1974, nov. 2011.

SATOLO, E. G.; CALARGE, F. A. O emprego de Sistema Integrado de Gestão na agroindústria sucroalcooleira: um estudo de caso na região de Piracicaba/SPEnegep. Anais...2008

SEARCY, C. et al. Challenges in implementing a functional ISO 14001 environmental management system. International Journal of Quality \& Reliability Management, v. 29, n. 7, p. 779-796, 2012. 
SHAW, O. Hot Tips for Implementing an Integrated Management System. IEE Engineering Management, v. 14, p. 10-13, 2004.

SIMON, A. et al. Integration of standardized environmental and quality management systems audits. Journal of Cleaner Production, v. 19, n. 17-18, p. 2057-2065, nov. 2011.

SIMON, A. et al. Implementing integrated management systems in chemical firms. Total Quality Management \& Business Excellence, v. 24, n. M3, p. 294-309, 2013.

SIMON, A.; DOUGLAS, A. Integrating management systems: does the location matter? International Journal of Quality \& Reliability Management, v. 30, n. 6, p. 675-689, 2013.

SIMON, A.; KARAPETROVIC, S.; CASADESÚS, M. Difficulties and benefits of integrated management systems. Industrial Management \& Data Systems, v. 112, n. 5, p. 828-846, 2012a.

SIMON, A.; KARAPETROVIC, S.; CASADESÚS, M. Evolution of Integrated Management Systems in Spanish firms. Journal of Cleaner Production, v. 23, n. 1, p. 8-19, mar. 2012b.

SINGH, S. An integrative approach to management systems and business excellence. African Journal of Business Management, v. 5, n. 5, p. 1618-1629, 2011.

TARÍ, J. J.; MOLINA-AZORÍN, J. F. Integration of quality management and environmental management systems: Similarities and the role of the EFQM model. The TQM Journal, v. 22, n. 6, p. 687-701, 2010.

TO, W. M.; LEE, P. K. C.; YU, B. T. W. Benefits of implementing management system standards: A case study of certified companies in the Pearl River Delta, China. The TQM Journal, v. 24, n. 1, p. 17-28, 2012.

VITORELI, G. A. Análise da integração dos sistemas de gestão normalizados ISO 9001 e OHSAS 18001: estudo de casos múltiplos. [s.l.] USP, 2011.

VITORELI, G. A. et al. Estruturação de um programa de qualificação em gestão da qualidade , segurança e saúde ocupacional: apresentação dos resultados de uma aplicação piloto realizada no aglomerado metal-mecânico de Sertãozinho - São Paulo. Gestão \& Produção, p. 689-704, 2012.

VITORELI, G. A.; CARPINETTI, L. C. R. Análise da integração dos sistemas de gestão normalizados ISO 9001 e OHSAS 18001 : Estudo de casos múltiplos. Gestão \& Produção, v. 20, n. 1, p. 204-217, 2013.

WENDLER, R. The maturity of maturity model research: A systematic mapping study. Information and Software Technology, v. 54, n. 12, p. 1317-1339, dez. 2012.

WILKINSON, G.; DALE, B. G. Models of Management System Standards: A Review of the Integration Issues. International Journal of Management Reviews, v. 1, n. 3, p. 279-298, set. 1999. 
WILKINSON, G.; DALE, B. G. An examination of the ISO 9001 : 2000 standard and its influence on the integration of management systems. Production Planning \& Control: The Management of Operations, v. 13, n. 3, p. 284-297, 2002.

ZENG, S. X.; SHI, J. J.; LOU, G. X. A synergetic model for implementing an integrated management system: an empirical study in China. Journal of Cleaner Production, v. 15, n. 18, p. 1760-1767, dez. 2007.

ZENG, S. X.; TAM, C. M.; TAM, V. W. Y. Integrating Safety , Environmental and Quality Risks for Project Management Using a FMEA Method. Inzinerine Ekonomika-Engineering Economics, v. 21, n. 1, p. 44-52, 2010.

ZENG, S. X.; TAM, V. W. Y.; LE, K. N. Towards Effectiveness of Integrated Management Systems for Enterprises. Inzinerine Ekonomika-Engineering Economics, v. 21, n. 2, p. 171-179, 2010.

ZENG, S. X.; TAM, V. W. Y.; TAM, C. M. Towards occupational health and safety systems in the construction industry of China. Safety Science, v. 46, n. 8, p. 1155-1168, out. 2008.

ZENG, S. X.; TIAN, P.; SHI, J. J. Implementing integration of ISO 9001 and ISO 14001 for construction. Managerial Auditing Journal, v. 20, n. 4, p. 394-407, 2005.

ZUTSHI, A.; SOHAL, A. S. Integrated management system: The experiences of three Australian organisations. Journal of Manufacturing Technology Management, v. 16, n. 2, p. 211-232, 2005. 


\section{APÊNDICE A - Resumo dos trabalhos encontrados sobre SGI}

Resumo dos trabalhos pesquisados sobre SGI. Além de informações gerais sobre os autores, título do artigo, ano de publicação, país onde a pesquisa foi desenvolvida e resumo das principais contribuições da pesquisa.

\begin{tabular}{|l|l|l|l|l|}
\hline \multicolumn{1}{|c|}{ Autor } & \multicolumn{1}{|c|}{ Título } & Ano & \multicolumn{1}{c|}{ País } & \multicolumn{1}{c|}{$\begin{array}{c}\text { Principais } \\
\text { Contribuições }\end{array}$} \\
\hline $\begin{array}{l}\text { Al-Darrab, I.A., } \\
\text { Gulzar, W.A., Ali, } \\
\text { K.S. }\end{array}$ & $\begin{array}{l}\text { Status of implementation of } \\
\text { safety, quality and } \\
\text { environmental management } \\
\text { systems in Saudi Arabian } \\
\text { industries }\end{array}$ & 2013 & $\begin{array}{l}\text { Arábia } \\
\text { Saudita }\end{array}$ & $\begin{array}{l}\text { O artigo revela que a } \\
\text { implantação de sistemas } \\
\text { integrados na Arábia Saudita } \\
\text { não tem ocorrido de forma } \\
\text { efetiva }\end{array}$ \\
\hline $\begin{array}{l}\text { Almeida, A.S.L.; } \\
\text { Melo, R.M.; } \\
\text { Gonçalves, H.S.; } \\
\text { Silva, D.E.P.; } \\
\text { Medeiros, D.D. }\end{array}$ & $\begin{array}{l}\text { Proposição de um modelo de } \\
\text { gestão do conhecimento para } \\
\text { empresas com Sistemas } \\
\text { Integrados de Gestão }\end{array}$ & 2007 & Brasil & $\begin{array}{l}\text { Relação entre gestão do } \\
\text { conhecimento e SGI. }\end{array}$ \\
\hline $\begin{array}{l}\text { Arifin, K.; Aiyub, } \\
\text { K.; Awang, A.; } \\
\text { Jahi, J.; Iteng, R. }\end{array}$ & $\begin{array}{l}\text { Implementation of Integrated } \\
\text { Management System in } \\
\text { Malaysia : The Level of } \\
\text { Organization s Understanding } \\
\text { and Awareness }\end{array}$ & 2009 & Malásia & $\begin{array}{l}\text { Análise sobre quão preparadas } \\
\text { as empresas da Malásia estão } \\
\text { para a integração; avaliando o } \\
\text { conhecimento e competência } \\
\text { da equipe. }\end{array}$ \\
\hline $\begin{array}{l}\text { Asif, M.; Fisscher, } \\
\text { O.; Bruijn, E. J.; } \\
\text { Pagell, M. }\end{array}$ & $\begin{array}{l}\text { An examination of strategies } \\
\text { employed for the integration of } \\
\text { management systems }\end{array}$ & 2010 & Paquistão & $\begin{array}{l}\text { Aborda as estratégias } \\
\text { empregadas na integração e sua } \\
\text { efetividade. }\end{array}$ \\
\hline $\begin{array}{l}\text { Azadeh, A.; } \\
\text { Farmand, A.H.; } \\
\text { Sharahi, Z.J. } \\
\text { anultivariate approach in a } \\
\text { arge conventional power plant } \\
\text { manufacturer }\end{array}$ & $\begin{array}{l}\text { Performance assessment and } \\
\text { optimization of HSE } \\
\text { anagement systems with }\end{array}$ & 2012 & Irã & $\begin{array}{l}\text { Avaliação do desempenho e } \\
\text { otimização de um sistema de } \\
\text { gestão integrado usando o } \\
\text { Fuzzy DEA (Análise de } \\
\text { Envoltória de Dados). }\end{array}$ \\
\hline
\end{tabular}

Figura 17 - Resumo dos trabalhos sobre SGI (continua) 


\begin{tabular}{|c|c|c|c|c|}
\hline $\begin{array}{l}\text { Bamber, C. J.; } \\
\text { Sharp, J.M.; Castka, } \\
\text { P. }\end{array}$ & $\begin{array}{l}\text { Third party assessment: the } \\
\text { role of the maintenance } \\
\text { function in an integrated } \\
\text { management system }\end{array}$ & 2004 & $\begin{array}{l}\text { Reino } \\
\text { Unido }\end{array}$ & $\begin{array}{l}\text { Avalia como manter o SGI e } \\
\text { como isso adiciona valor nos } \\
\text { processos. }\end{array}$ \\
\hline $\begin{array}{l}\text { Beckmerhagen, I. } \\
\text { A.; Berg, H. P.; } \\
\text { Karapetrovic, S. V.; } \\
\text { Willborn, W. O. }\end{array}$ & $\begin{array}{l}\text { Integration of management } \\
\text { systems: focus on safety in the } \\
\text { nuclear industry }\end{array}$ & 2003 & Alemanha & $\begin{array}{l}\text { Esse artigo responde questões } \\
\text { centrais sobre integração e } \\
\text { apresenta um estudo de caso } \\
\text { em uma indústria nuclear onde } \\
\text { questões de segurança são } \\
\text { fundamentais. }\end{array}$ \\
\hline $\begin{array}{l}\text { Bernardo, M.; } \\
\text { Casadesus, M.; } \\
\text { Karapetrovic, S.; } \\
\text { Heras, I. }\end{array}$ & $\begin{array}{l}\text { How integrated are } \\
\text { environmental, quality and } \\
\text { other standardized } \\
\text { management systems? An } \\
\text { empirical study }\end{array}$ & 2009 & Espanha & $\begin{array}{l}\text { Análise sobre estratégias, } \\
\text { metodologias e graus de } \\
\text { integração. }\end{array}$ \\
\hline $\begin{array}{l}\text { Bernardo, M.; } \\
\text { Casadesus, M.; } \\
\text { Karapetrovic, S.; } \\
\text { Heras, I. }\end{array}$ & $\begin{array}{l}\text { An empirical study on the } \\
\text { integration of management } \\
\text { system audits }\end{array}$ & 2010 & Espanha & $\begin{array}{l}\text { Análise das auditorias internas } \\
\text { e externas em empresas que } \\
\text { integram seus sistemas de } \\
\text { gestão. }\end{array}$ \\
\hline $\begin{array}{l}\text { Bernardo, M.; } \\
\text { Casadesus, M.; } \\
\text { Karapetrovic, S.; } \\
\text { Heras, I. }\end{array}$ & $\begin{array}{l}\text { Relationships between the } \\
\text { integration of audits and } \\
\text { management systems: An } \\
\text { empirical study }\end{array}$ & 2011 & Espanha & $\begin{array}{l}\text { Relação entre nível de } \\
\text { integração das auditorias } \\
\text { internas/externas e nível de } \\
\text { integração do SGI. }\end{array}$ \\
\hline $\begin{array}{l}\text { Bernardo, M.; } \\
\text { Casadesus, M.; } \\
\text { Karapetrovic, S.; } \\
\text { Heras, I. }\end{array}$ & $\begin{array}{l}\text { Integration of standardized } \\
\text { management systems: does the } \\
\text { implementation order matter? }\end{array}$ & $2012 a$ & Espanha & $\begin{array}{l}\text { Apresenta a sequência de } \\
\text { implantação que traz maior } \\
\text { resultado na integração e } \\
\text { sugere para empresas iniciantes } \\
\text { na integração. }\end{array}$ \\
\hline $\begin{array}{l}\text { Bernardo, M.; } \\
\text { Casadesus, M.; } \\
\text { Karapetrovic, S.; } \\
\text { Heras, I. }\end{array}$ & $\begin{array}{l}\text { Do integration difficulties } \\
\text { influence management system } \\
\text { integration levels? }\end{array}$ & $2012 b$ & Espanha & $\begin{array}{l}\text { Estuda a relação entre o nível } \\
\text { de integração e as dificuldades } \\
\text { de integração }\end{array}$ \\
\hline Boiral, O. & $\begin{array}{l}\text { Managing with ISO Systems: } \\
\text { Lessons from Practice }\end{array}$ & 2011 & Canadá & $\begin{array}{l}\text { Apresenta armadilhas e fatores } \\
\text { de sucesso na implantação da } \\
\text { ISO. }\end{array}$ \\
\hline $\begin{array}{l}\text { Botta, S.; } \\
\text { Comoglio, C.; } \\
\text { Petrosillo, I. }\end{array}$ & $\begin{array}{l}\text { Implementing the } \\
\text { environmental and social } \\
\text { policies of a municipality } \\
\text { through an integrated } \\
\text { management system: } \\
\text { Theoretical framework and } \\
\text { case study }\end{array}$ & 2012 & Itália & $\begin{array}{l}\text { Estabelece um framework para } \\
\text { integração de sistemas de } \\
\text { gestão ambiental e social em } \\
\text { município italiano. }\end{array}$ \\
\hline
\end{tabular}

Figura 17 - Resumo dos trabalhos sobre SGI (continuação) 


\begin{tabular}{|c|c|c|c|c|}
\hline $\begin{array}{l}\text { Brendler, E.; } \\
\text { Brandli, L.L. }\end{array}$ & $\begin{array}{l}\text { Integração do sistema de } \\
\text { gestão ambiental } \\
\text { no sistema de gestão de } \\
\text { qualidade em } \\
\text { uma indústria de confecções }\end{array}$ & 2011 & Brasil & $\begin{array}{l}\text { Mostra a estruturação do } \\
\text { sistema de gestão ambiental } \\
\text { com base no sistema de gestão } \\
\text { da qualidade, apontando as } \\
\text { facilidades e dificuldades do } \\
\text { SGI. }\end{array}$ \\
\hline $\begin{array}{l}\text { Campos, C.A.O.; } \\
\text { Medeiros, D.D. }\end{array}$ & $\begin{array}{l}\text { Um modelo de integração de } \\
\text { sistemas de gestão }\end{array}$ & 2009 & Brasil & $\begin{array}{l}\text { Estudo sobre a viabilidade de } \\
\text { se integrar, utilizando para isso } \\
\text { modelo matemático. }\end{array}$ \\
\hline $\begin{array}{l}\text { Casadesus, M.; } \\
\text { Karapetrovic, S.; } \\
\text { Heras, I. }\end{array}$ & $\begin{array}{l}\text { Synergies in standardized } \\
\text { management systems: some } \\
\text { empirical evidence }\end{array}$ & 2011 & Espanha & $\begin{array}{l}\text { Relação entre implantação de } \\
\text { SGI e resultados alcançados } \\
\text { com a integração. }\end{array}$ \\
\hline de Oliveira, O. J. & $\begin{array}{l}\text { Guidelines for the integration } \\
\text { of certifiable management } \\
\text { systems in industrial } \\
\text { companies }\end{array}$ & 2013 & Brasil & $\begin{array}{l}\text { O artigo realiza estudo de caso } \\
\text { em } 14 \text { empresas e com base } \\
\text { nisso propõe um guia para } \\
\text { integração dos sistemas de } \\
\text { gestão }\end{array}$ \\
\hline $\begin{array}{l}\text { Domingues, P.; } \\
\text { Sampaio, P.; } \\
\text { Arezes, P.; Ramos, } \\
\text { G. }\end{array}$ & $\begin{array}{l}\text { Integrated OHS Management } \\
\text { Systems: is it the final frontier } \\
\text { regarding OHS? }\end{array}$ & 2012 & Portugal & $\begin{array}{l}\text { Panorama da integração de } \\
\text { sistemas de gestão em } \\
\text { Portugal. }\end{array}$ \\
\hline $\begin{array}{l}\text { Drożyner, P.; } \\
\text { Mikołajczak, P.; } \\
\text { Szuszkiewicz, J.; } \\
\text { Jasiulewicz- } \\
\text { Kaczmarek, M. }\end{array}$ & $\begin{array}{l}\text { Management Standardization } \\
\text { Versus Quality of Working } \\
\text { Life }\end{array}$ & 2011 & Polônia & $\begin{array}{l}\text { Pesquisa sobre a relação entre } \\
\text { SGI e aumento da qualidade de } \\
\text { vida no trabalho. }\end{array}$ \\
\hline $\begin{array}{l}\text { Gangolells, M.; } \\
\text { Casals, M.; } \\
\text { Forcada, N.; } \\
\text { Fuertes, A.; Roca, } \\
\text { X. }\end{array}$ & $\begin{array}{l}\text { Model for Enhancing } \\
\text { Integrated Identification, } \\
\text { Assessment , and Operational } \\
\text { Control of On-Site } \\
\text { Environmental Impacts and } \\
\text { Health and Safety Risks in } \\
\text { Construction Firms }\end{array}$ & 2013 & Espanha & $\begin{array}{l}\text { Apresenta um modelo para } \\
\text { aumentar a integração de } \\
\text { sistemas de gestão ambiental e } \\
\text { de saúde e segurança em } \\
\text { indústrias de construção. }\end{array}$ \\
\hline $\begin{array}{l}\text { Garengo, P.; } \\
\text { Biazzo, S. }\end{array}$ & $\begin{array}{l}\text { Total Quality Management \& } \\
\text { Business Excellence From ISO } \\
\text { quality standards to an } \\
\text { integrated management system } \\
\text { : an implementation process in } \\
\text { SME }\end{array}$ & 2013 & Itália & $\begin{array}{l}\text { O artigo aborda a integração } \\
\text { sobre o aspecto das pequenas } \\
\text { empresas e tomando como base } \\
\text { a ISO9001 }\end{array}$ \\
\hline
\end{tabular}

Figura 17 - Resumo dos trabalhos sobre SGI (continuação) 


\begin{tabular}{|c|c|c|c|c|}
\hline $\begin{array}{l}\text { Griffith, A.; Bhutto, } \\
\text { K. }\end{array}$ & $\begin{array}{l}\text { Improving environmental } \\
\text { performance through } \\
\text { integrated management } \\
\text { systems (IMS) in the UK }\end{array}$ & 2008 & $\begin{array}{l}\text { Reino } \\
\text { Unido }\end{array}$ & $\begin{array}{l}\text { Como a integração dos } \\
\text { sistemas de gestão dentro do } \\
\text { setor de construção pode } \\
\text { contribuir para a melhoria } \\
\text { ambiental. }\end{array}$ \\
\hline $\begin{array}{l}\text { Heras-Saizarbitoria, } \\
\text { I.; Boiral, O. }\end{array}$ & $\begin{array}{l}\text { ISO } 9001 \text { and ISO 14001: } \\
\text { Towards a } \\
\text { Research Agenda on } \\
\text { Management } \\
\text { System Standards }\end{array}$ & 2012 & Canadá & $\begin{array}{l}\text { Levantamento da bibliografia } \\
\text { existente e principais lacunas } \\
\text { que poderão ser tratados em } \\
\text { pesquisas futuras. }\end{array}$ \\
\hline Holdsworth, R. & $\begin{array}{l}\text { Practical applications approach } \\
\text { to design, development and } \\
\text { implementation of an } \\
\text { integrated management system }\end{array}$ & 2003 & $\begin{array}{l}\text { Estados } \\
\text { Unidos }\end{array}$ & $\begin{array}{l}\text { Aborda o projeto, } \\
\text { desenvolvimento e implantação } \\
\text { do SGI. }\end{array}$ \\
\hline Jørgensen, T. H. & $\begin{array}{l}\text { Towards more sustainable } \\
\text { management systems: through } \\
\text { life cycle management and } \\
\text { integration }\end{array}$ & 2008 & Dinamarca & $\begin{array}{l}\text { Esse trabalho relaciona níveis } \\
\text { de integração com } \\
\text { desenvolvimento sustentável. }\end{array}$ \\
\hline $\begin{array}{l}\text { Jørgensen, T.; } \\
\text { Remmen, A.; } \\
\text { Mellado, M. }\end{array}$ & $\begin{array}{l}\text { Integrated management } \\
\text { systems - three different levels } \\
\text { of integration. }\end{array}$ & 2006 & Dinamarca & $\begin{array}{l}\text { Apresenta } 3 \text { níveis de } \\
\text { integração. }\end{array}$ \\
\hline Karapetrovic, S. & $\begin{array}{l}\text { Strategies for the integration of } \\
\text { management systems and } \\
\text { standards }\end{array}$ & 2002 & Canadá & $\begin{array}{l}\text { Apresenta idéias para o } \\
\text { desenvolvimento do SGI e } \\
\text { metodologias de auditoria. }\end{array}$ \\
\hline $\begin{array}{l}\text { Karapetrovic, S.; } \\
\text { Casadesús, M. }\end{array}$ & $\begin{array}{l}\text { Implementing environmental } \\
\text { with other standardized } \\
\text { management systems: Scope, } \\
\text { sequence, time and integration }\end{array}$ & 2009 & Espanha & $\begin{array}{l}\text { Análise sobre as normas quais } \\
\text { costumam integrar, a sequência } \\
\text { da integração dessas normas e } \\
\text { o tempo para que a integração } \\
\text { ocorra. }\end{array}$ \\
\hline $\begin{array}{l}\text { Karapetrovic, S.; } \\
\text { Willborn, W. }\end{array}$ & $\begin{array}{l}\text { Integration of quality and } \\
\text { environmental management } \\
\text { systems }\end{array}$ & 1998 & Canadá & $\begin{array}{l}\text { Descrição sobre o que são } \\
\text { sistemas integrados. Apresenta } \\
\text { as estratégias de integração, } \\
\text { benefícios e dificuldades. }\end{array}$ \\
\hline $\begin{array}{l}\text { Khanna, H.K.; } \\
\text { Laroiya, S.C.; } \\
\text { Sharma, D.D. }\end{array}$ & $\begin{array}{l}\text { Integrated management } \\
\text { systems in Indian } \\
\text { manufacturing organizations }\end{array}$ & 2010 & Índia & $\begin{array}{l}\text { Levanta a situação da } \\
\text { integração na Îndia, assim } \\
\text { como os benefícios e } \\
\text { motivações para se integrar. }\end{array}$ \\
\hline
\end{tabular}

Figura 17 - Resumo dos trabalhos sobre SGI (continuação) 


\begin{tabular}{|c|c|c|c|c|}
\hline $\begin{array}{l}\text { Leopoulos, V.; } \\
\text { Voulgaridou, D.; } \\
\text { Bellos, E.; } \\
\text { Kirytopoulos, K. }\end{array}$ & $\begin{array}{l}\text { Integrated management } \\
\text { systems: moving from function } \\
\text { to organisation/decision view }\end{array}$ & 2010 & Grécia & $\begin{array}{l}\text { A integração deve ser feita com } \\
\text { vista as } 4 \text { visões de modelagem } \\
\text { da empresa: função, } \\
\text { informação, recursos e } \\
\text { organização. }\end{array}$ \\
\hline López-Fresno, P. & $\begin{array}{l}\text { Implementation of an } \\
\text { integrated management system } \\
\text { in an airline: a case study }\end{array}$ & 2010 & Espanha & $\begin{array}{l}\text { Estudo de caso sobre a } \\
\text { integração de todas as normas } \\
\text { da empresa, incluindo as } \\
\text { específicas do setor em que } \\
\text { atua. }\end{array}$ \\
\hline Mackau, D. & $\begin{array}{l}\text { SME integrated management } \\
\text { system: a proposed } \\
\text { experiences model }\end{array}$ & 2003 & Alemanha & $\begin{array}{l}\text { Proposta de um modelo para } \\
\text { integrar os sistemas de gestão e } \\
\text { aplicação em uma empresa } \\
\text { alemã. }\end{array}$ \\
\hline $\begin{array}{l}\text { Majstorović, V.D.; } \\
\text { Marinković, V. }\end{array}$ & $\begin{array}{l}\text { The Development of Business } \\
\text { Standardization and Integrated } \\
\text { Management Systems }\end{array}$ & 2011 & Sérvia & $\begin{array}{l}\text { Apresenta uma proposta de } \\
\text { modelo de integração. }\end{array}$ \\
\hline $\begin{array}{l}\text { Marimba, A.; } \\
\text { Farinha, J.T.; } \\
\text { Ferreira, L. }\end{array}$ & $\begin{array}{l}\text { International standards } \\
\text { integration for ecologic asset } \\
\text { management }\end{array}$ & 2010 & Portugal & $\begin{array}{l}\text { Aborda a integração de } \\
\text { diversas normas para promover } \\
\text { a sustentabilidade e propõe um } \\
\text { indicador denominado Nível de } \\
\text { Produção Sustentável para } \\
\text { auxiliar consumidores, } \\
\text { empresas e fornecedores na } \\
\text { tomada de decisão. }\end{array}$ \\
\hline $\begin{array}{l}\text { Mežinska, I.; } \\
\text { Lapiņa, I.; Mazais, } \\
\text { J. }\end{array}$ & $\begin{array}{l}\text { Integrated management } \\
\text { systems towards sustainable } \\
\text { and socially responsible } \\
\text { organisation }\end{array}$ & 2013 & Letônia & $\begin{array}{l}\text { Essa pesquisa aborda a questão } \\
\text { do grau de integração (não } \\
\text { integrado, parcialmente e } \\
\text { totalmente integrado) sob a } \\
\text { perspectiva do } \\
\text { desenvolvimento sustentável }\end{array}$ \\
\hline $\begin{array}{l}\text { Milliman, J.; } \\
\text { Grosskopf, J.; Paez, } \\
\text { O.; Ayen, W. }\end{array}$ & $\begin{array}{l}\text { Pilot project results of an } \\
\text { integrated security } \\
\text { management system }\end{array}$ & 2005 & $\begin{array}{l}\text { Estados } \\
\text { Unidos }\end{array}$ & $\begin{array}{l}\text { Apresenta um modelo de } \\
\text { integração para SGI. }\end{array}$ \\
\hline Nee, A.Y.H. & $\begin{array}{l}\text { Implementation of Integrated } \\
\text { Management System : } \\
\text { Environmental and Safety } \\
\text { Performance and Global } \\
\text { Sustainability }\end{array}$ & 2009 & Malásia & $\begin{array}{l}\text { Análise de como acontece a } \\
\text { integração das normas em } \\
\text { empresas da Malásia, levando } \\
\text { em conta a realidade do país. }\end{array}$ \\
\hline
\end{tabular}

Figura 17 - Resumo dos trabalhos sobre SGI (continuação) 


\begin{tabular}{|c|c|c|c|c|}
\hline $\begin{array}{l}\text { Nitu, L.D.; Nitu, L.; } \\
\text { Solomon, G. }\end{array}$ & $\begin{array}{l}\text { Model for Conformity } \\
\text { Assessment of Integrated } \\
\text { Management Systems }\end{array}$ & 2012 & Romênia & $\begin{array}{l}\text { Propõe um modelo para } \\
\text { avaliação quantitativa da } \\
\text { integração dos sistemas de } \\
\text { gestão. }\end{array}$ \\
\hline $\begin{array}{l}\text { Nouri, J.; } \\
\text { Abbaspour, M.; } \\
\text { Fard, M.T.; Fam, } \\
\text { I.M. }\end{array}$ & $\begin{array}{l}\text { Advantages of integrated } \\
\text { management system in } \\
\text { educational centers }\end{array}$ & 2010 & Irã & $\begin{array}{l}\text { Implantação de SGI em uma } \\
\text { universidade no Irã. }\end{array}$ \\
\hline $\begin{array}{l}\text { Ofori, G.; Gang, G.; } \\
\text { Bri, C. }\end{array}$ & $\begin{array}{l}\text { Implementing environmental } \\
\text { management systems in } \\
\text { construction : lessons from } \\
\text { quality systems }\end{array}$ & 2002 & Singapura & $\begin{array}{l}\text { Análise sobre certificações na } \\
\text { indústria de construção civil de } \\
\text { Singapura. A maioria das } \\
\text { empresas possuem ISO9001, } \\
\text { mas poucas possuem } \\
\text { ISO14001 e a integração de } \\
\text { ambas seria muito importante. }\end{array}$ \\
\hline $\begin{array}{l}\text { Pheng, L.S.; Pong, } \\
\text { C.Y. }\end{array}$ & $\begin{array}{l}\text { Integrating ISO } 9001 \text { and } \\
\text { OHSAS } 18001 \text { for } \\
\text { Construction }\end{array}$ & 2003 & Singapura & $\begin{array}{l}\text { Benefícios e dificuldades da } \\
\text { integração em indústria da } \\
\text { construção civil. }\end{array}$ \\
\hline Pojasek, R. B. & $\begin{array}{l}\text { Is Your Integrated } \\
\text { Management System Really } \\
\text { Integrated? }\end{array}$ & 2006 & $\begin{array}{l}\text { Estados } \\
\text { Unidos }\end{array}$ & $\begin{array}{l}\text { Apresenta os passos para } \\
\text { integração e duas ferramentas } \\
\text { que auxiliam nesse processo. }\end{array}$ \\
\hline $\begin{array}{l}\text { Popescu, S. G.; } \\
\text { Tifrea, D. I. }\end{array}$ & $\begin{array}{l}\text { Quality Management Systems' } \\
\text { Maturity, a measure of the ISO } \\
9001 \text { implementation process }\end{array}$ & 2011 & Romênia & $\begin{array}{l}\text { Avaliação do impacto da } \\
\text { implantação da ISO9001 em } \\
\text { pequenas empresas através do } \\
\text { CMMI. }\end{array}$ \\
\hline $\begin{array}{l}\text { Rebelo, M.; Santos, } \\
\text { G.; Silva, R. }\end{array}$ & $\begin{array}{l}\text { Conception of a flexible } \\
\text { integrator and lean model for } \\
\text { integrated management } \\
\text { systems }\end{array}$ & 2013 & Portugal & $\begin{array}{l}\text { É apresentado um modelo para } \\
\text { integração de diferentes } \\
\text { sistemas de gestão, sendo } \\
\text { baseados na filosofia Lean }\end{array}$ \\
\hline $\begin{array}{l}\text { Rocha, M.; Searcy, } \\
\text { C.; Karapetrovic, S. }\end{array}$ & $\begin{array}{l}\text { Integrating Sustainable } \\
\text { Development into Existing } \\
\text { Management Systems }\end{array}$ & 2007 & Canadá & $\begin{array}{l}\text { Apresenta um modelo de } \\
\text { integração para SGI e } \\
\text { apresenta uma visão de que o } \\
\text { SGI tem muito a contribuir } \\
\text { para o desenvolvimento } \\
\text { sustentável. }\end{array}$ \\
\hline Rönninger, S. & $\begin{array}{l}\text { Implementation of a Process- } \\
\text { Oriented ISO } 9000 \text { and ISO } \\
14000 \text { Management System in } \\
\text { a Chemical Manufacturing Site }\end{array}$ & 2002 & Suíça & $\begin{array}{l}\text { Apresenta como se deu a } \\
\text { integração das normas em uma } \\
\text { das divisões da Roche na } \\
\text { Suíça. }\end{array}$ \\
\hline
\end{tabular}

Figura 17 - Resumo dos trabalhos sobre SGI (continuação) 


\begin{tabular}{|c|c|c|c|c|}
\hline Salomone, R. & $\begin{array}{l}\text { Integrated management } \\
\text { systems: experiences in Italian } \\
\text { organizations }\end{array}$ & 2008 & Itália & $\begin{array}{l}\text { Relacionou os benefícios e } \\
\text { dificuldades enfrentados com } \\
\text { relação ao tamanho, setor e } \\
\text { região da empresa. Apresentou } \\
\text { graus de integração } \\
\text { (não/parcialmente/ totalmente } \\
\text { integrado) }\end{array}$ \\
\hline $\begin{array}{l}\text { Sampaio, P.; } \\
\text { Saraiva, P.; } \\
\text { Domingues, P. }\end{array}$ & $\begin{array}{l}\text { Management systems: } \\
\text { integration or addition? }\end{array}$ & 2012 & Portugal & $\begin{array}{l}\text { Análise sobre a sequência de } \\
\text { implantação X nível de } \\
\text { integração; principais motivos } \\
\text { para se integrar; quais as } \\
\text { normas mais fáceis de se } \\
\text { integrar; e a relação entre nível } \\
\text { de integração X desempenho. }\end{array}$ \\
\hline $\begin{array}{l}\text { Santos, G.; Barros, } \\
\text { S.; Mendes, F.; } \\
\text { Lopes, N. }\end{array}$ & $\begin{array}{l}\text { The main benefits associated } \\
\text { with health and safety } \\
\text { management systems } \\
\text { certification in Portuguese } \\
\text { small and medium enterprises } \\
\text { post quality management } \\
\text { system certification }\end{array}$ & 2013 & Portugal & $\begin{array}{l}\text { Mostra como as empresas } \\
\text { vêem a certificação de sistema } \\
\text { de gestão de saúde e segurança } \\
\text { ocupacional após terem } \\
\text { recebido a certificação do } \\
\text { sistemas de gestão da } \\
\text { qualidade. }\end{array}$ \\
\hline $\begin{array}{l}\text { Santos, G.; } \\
\text { Mendes, F.; } \\
\text { Barbosa, J. }\end{array}$ & $\begin{array}{l}\text { Certification and integration of } \\
\text { management systems: the } \\
\text { experience of Portuguese small } \\
\text { and medium enterprises }\end{array}$ & 2011 & Portugal & $\begin{array}{l}\text { Pesquisa focada em pequenas e } \\
\text { médias empresas de Portugal } \\
\text { com relação à integração. }\end{array}$ \\
\hline $\begin{array}{l}\text { Satolo, E.G.; } \\
\text { Calarge, F.A. }\end{array}$ & $\begin{array}{l}\text { O emprego de Sistema } \\
\text { Integrado de Gestão na } \\
\text { agroindústria sucroalcooleira: } \\
\text { um estudo de caso na região de } \\
\text { Piracicaba/SP }\end{array}$ & 2008 & Brasil & $\begin{array}{l}\text { Apresenta os graus de } \\
\text { integração, benefícios e } \\
\text { dificuldades. }\end{array}$ \\
\hline $\begin{array}{l}\text { Searcy, C.; Morali, } \\
\text { O.; Karapetrovic, } \\
\text { S.; Wichuk, K.; } \\
\text { McCartney, D.; } \\
\text { McLeod, S.; Fraser, } \\
\text { D. }\end{array}$ & $\begin{array}{l}\text { Challenges in implementing a } \\
\text { functional ISO } 14001 \\
\text { environmental management } \\
\text { system }\end{array}$ & 2012 & Canadá & $\begin{array}{l}\text { Pesquisa com especialistas em } \\
\text { gestão ambiental onde aborda: } \\
\text { questões críticas e sinergias } \\
\text { entre os elementos do sistema } \\
\text { de gestão, auditoria e } \\
\text { integração dos sistemas de } \\
\text { gestão. }\end{array}$ \\
\hline Shaw, O. & $\begin{array}{l}\text { Hot Tips for Implementing an } \\
\text { Integrated Management } \\
\text { System }\end{array}$ & 2004 & $\begin{array}{l}\text { Reino } \\
\text { Unido }\end{array}$ & $\begin{array}{l}\text { Apresenta o passo a passo para } \\
\text { realizar a integração a partir do } \\
\text { ponto de vista de um } \\
\text { especialista no assunto. }\end{array}$ \\
\hline
\end{tabular}

Figura 17 - Resumo dos trabalhos sobre SGI (continuação) 


\begin{tabular}{|c|c|c|c|c|}
\hline $\begin{array}{l}\text { Simon, A.; } \\
\text { Bernardo, M., } \\
\text { Karapetrovic, S.; } \\
\text { Casadesus, M. }\end{array}$ & $\begin{array}{l}\text { Integration of standardized } \\
\text { environmental and quality } \\
\text { management systems audits }\end{array}$ & 2011 & Espanha & $\begin{array}{l}\text { Levantamento sobre a } \\
\text { integração de auditorias do } \\
\text { SGI. }\end{array}$ \\
\hline $\begin{array}{l}\text { Simon, A.; } \\
\text { Bernardo, M., } \\
\text { Karapetrovic, S.; } \\
\text { Casadesus, M. }\end{array}$ & $\begin{array}{l}\text { Implementing integrated } \\
\text { management systems in } \\
\text { chemical firms }\end{array}$ & 2013 & Espanha & $\begin{array}{l}\text { O artigo realiza um survey } \\
\text { seguido de um estudo de caso } \\
\text { para avaliar a questão da } \\
\text { integração no setor químico }\end{array}$ \\
\hline $\begin{array}{l}\text { Simon, A.; } \\
\text { Douglas, A. }\end{array}$ & $\begin{array}{l}\text { Integrating management } \\
\text { systems: does the location } \\
\text { matter? }\end{array}$ & 2013 & Espanha/UK & $\begin{array}{l}\text { Esse artigo avalia se a } \\
\text { localização da empresa tem } \\
\text { impacto na integração e } \\
\text { conclui que as diferenças são } \\
\text { muito pequenas para se afirmar } \\
\text { que há essa diferenciação }\end{array}$ \\
\hline $\begin{array}{l}\text { Simon, A.; } \\
\text { Karapetrovic, S.; } \\
\text { Casadesus }\end{array}$ & $\begin{array}{l}\text { Difficulties and benefits of } \\
\text { integrated management } \\
\text { systems. }\end{array}$ & $2012 a$ & Espanha & $\begin{array}{l}\text { Como as dificuldades e } \\
\text { benefícios da integração se } \\
\text { relacionam com o nível de } \\
\text { integração das empresas. }\end{array}$ \\
\hline $\begin{array}{l}\text { Simon, A.; } \\
\text { Karapetrovic, S.; } \\
\text { Casadesus }\end{array}$ & $\begin{array}{l}\text { Evolution of Integrated } \\
\text { Management Systems in } \\
\text { Spanish firms }\end{array}$ & $2012 b$ & Espanha & $\begin{array}{l}\text { Entender como as empresas } \\
\text { integram e como percebem os } \\
\text { desafios ao longo do tempo, no } \\
\text { caso da pesquisa ao longo de } 4 \\
\text { anos. }\end{array}$ \\
\hline Singh, $\mathrm{S}$. & $\begin{array}{l}\text { An integrative approach to } \\
\text { management systems and } \\
\text { business excellence }\end{array}$ & 2011 & $\begin{array}{l}\text { África do } \\
\text { Sul }\end{array}$ & $\begin{array}{l}\text { Proposta de um modelo para } \\
\text { integrar normas, tendo como } \\
\text { foco a preocupação com a } \\
\text { AIDS e governança } \\
\text { corporativa. }\end{array}$ \\
\hline $\begin{array}{l}\text { Tarí, J.J.; Molina- } \\
\text { Azorín, J.F. }\end{array}$ & $\begin{array}{l}\text { Integration of quality } \\
\text { management and } \\
\text { environmental management } \\
\text { systems: Similarities and the } \\
\text { role of the EFQM model }\end{array}$ & 2010 & Espanha & $\begin{array}{l}\text { Utilização do modelo EFQM } \\
\text { (European Foundation for } \\
\text { Quality Management) para } \\
\text { promover a integração. }\end{array}$ \\
\hline $\begin{array}{l}\text { To, W.M.; Lee, } \\
\text { Peter K.C.;Yu, } \\
\text { Billy T.W. }\end{array}$ & $\begin{array}{l}\text { Benefits of implementing } \\
\text { management system standards: } \\
\text { A case study of certified } \\
\text { companies in the Pearl River } \\
\text { Delta, China }\end{array}$ & 2012 & China & $\begin{array}{l}\text { Relaciona a integração com } \\
\text { desempenho da empresa, } \\
\text { qualidade do produto e } \\
\text { marketing, sendo que as } \\
\text { empresas que integram tem } \\
\text { desempenho maior nesses } \\
\text { quesitos. }\end{array}$ \\
\hline
\end{tabular}

Figura 17 - Resumo dos trabalhos sobre SGI (continuação) 


\begin{tabular}{|c|c|c|c|c|}
\hline $\begin{array}{l}\text { Vitoreli, G. A.; } \\
\text { Carpinetti, L. C. } \\
\text { R.; Gerolamo, M. } \\
\text { C.; Sordan, J. E.; } \\
\text { Lima, C. H. B. }\end{array}$ & $\begin{array}{l}\text { Estruturação de um programa } \\
\text { de qualificação em gestão da } \\
\text { qualidade, segurança e saúde } \\
\text { ocupacional : apresentação dos } \\
\text { resultados de uma aplicação } \\
\text { piloto realizada no aglomerado } \\
\text { metal-mecânico de Sertãozinho } \\
\text { - São Paulo }\end{array}$ & 2012 & Brasil & $\begin{array}{l}\text { Proposta de um modelo de } \\
\text { SGI, incluindo o passo a passo } \\
\text { desde a implantação até } \\
\text { auditoria e tendo como foco } \\
\text { pequenas e médias empresas de } \\
\text { um aglomerado metal- } \\
\text { mecânico. }\end{array}$ \\
\hline Vitoreli, G.A. & $\begin{array}{l}\text { Análise da integração dos } \\
\text { sistemas de gestão } \\
\text { normalizados ISO } 9001 \text { e } \\
\text { OHSAS 18001: estudo de } \\
\text { casos múltiplos }\end{array}$ & 2011 & Brasil & $\begin{array}{l}\text { Detalha o processo de } \\
\text { integração, focando na } \\
\text { implantação de um SGI, } \\
\text { estrutura adotada e requisitos } \\
\text { da norma integrados. }\end{array}$ \\
\hline $\begin{array}{l}\text { Vitoreli, G.A; } \\
\text { Carpinetti, L.C.R. }\end{array}$ & $\begin{array}{l}\text { Analysis of the integration of } \\
\text { normalized management } \\
\text { systems ISO } 9001 \text { and OHSAS } \\
\text { 18001: Multiple case studies }\end{array}$ & 2013 & Brasil & $\begin{array}{l}\text { Artigo sobre a dissertação de } \\
\text { mestrado, a qual foca na } \\
\text { implantação de um SGI, } \\
\text { estrutura adotada e requisitos } \\
\text { da norma integrados. }\end{array}$ \\
\hline $\begin{array}{l}\text { Wilkinson, G.; } \\
\text { Dale, B. G. }\end{array}$ & $\begin{array}{l}\text { Models of Management } \\
\text { System Standards: A Review } \\
\text { of the Integration Issues }\end{array}$ & 1999 & $\begin{array}{l}\text { Reino } \\
\text { Unido }\end{array}$ & $\begin{array}{l}\text { Análise sobre os modelos de } \\
\text { integração encontrados na } \\
\text { literatura e a relação com o } \\
\text { aspecto cultural. }\end{array}$ \\
\hline $\begin{array}{l}\text { Wilkinson, G.; } \\
\text { Dale, B. G. }\end{array}$ & $\begin{array}{l}\text { An examination of the ISO } \\
9001: 2000 \text { standard and its } \\
\text { influence on the integration of } \\
\text { management systems }\end{array}$ & 2002 & $\begin{array}{l}\text { Reino } \\
\text { Unido }\end{array}$ & $\begin{array}{l}\text { Análise sobre a } \\
\text { compatibilidade entre as } \\
\text { normas. }\end{array}$ \\
\hline $\begin{array}{l}\text { Zeng, S.X.; Shi, } \\
\text { J.J.; Lou, G.X. }\end{array}$ & $\begin{array}{l}\text { A synergetic model for } \\
\text { implementing an integrated } \\
\text { management system: an } \\
\text { empirical study in China }\end{array}$ & 2007 & China & $\begin{array}{l}\text { Apresenta os problemas } \\
\text { enfrentados pelas empresas que } \\
\text { trabalham com os sistemas de } \\
\text { gestão de forma paralela; } \\
\text { fatores internos e externos que } \\
\text { afetam na integração e propõe } \\
\text { um modelo de vários níveis } \\
\text { para realizar a integração. }\end{array}$ \\
\hline $\begin{array}{l}\text { Zeng, S.X.; Tam, } \\
\text { C.M.; Tam, V.W.Y. }\end{array}$ & $\begin{array}{l}\text { Integrating Safety, } \\
\text { Environmental and Quality } \\
\text { Risks for Project Management } \\
\text { Using a FMEA Method }\end{array}$ & 2010 & China & $\begin{array}{l}\text { Utilização do FMEA para } \\
\text { avaliar o risco de se ter } \\
\text { problemas relacionados à saúde } \\
\text { e segurança, qualidade e } \\
\text { ambiente, procurando avaliar } \\
\text { de forma integrada os riscos. }\end{array}$ \\
\hline
\end{tabular}

Figura 17 - Resumo dos trabalhos sobre SGI (continuação) 


\begin{tabular}{|l|l|l|l|l|}
\hline $\begin{array}{l}\text { Zeng, S.X.; Tam, } \\
\text { V.W.Y.; Le, K.N. }\end{array}$ & $\begin{array}{l}\text { Towards Effectiveness of } \\
\text { Integrated Management } \\
\text { Systems for Enterprises }\end{array}$ & 2010 & China & $\begin{array}{l}\text { Aborda as motivações e } \\
\text { benefícios da implantação de } \\
\text { SGI na China. }\end{array}$ \\
\hline $\begin{array}{l}\text { Zeng, S.X.; Tam, } \\
\text { V.W.Y.; Tam, C.M. }\end{array}$ & $\begin{array}{l}\text { Towards occupational health } \\
\text { and safety systems in the } \\
\text { construction industry of China }\end{array}$ & 2008 & China & $\begin{array}{l}\text { Aborda a integração da } \\
\text { ISO9001 e OHSAS18001 no } \\
\text { setor de construção civil na } \\
\text { China e o quanto essa } \\
\text { integração poderia auxiliar na } \\
\text { redução de acidentes. }\end{array}$ \\
\hline $\begin{array}{l}\text { Zeng, S.X.; Tian, } \\
\text { P.; Shi, J. J. }\end{array}$ & $\begin{array}{l}\text { Implementing integration of } \\
\text { ISO 9001 and ISO 14001 for } \\
\text { construction }\end{array}$ & 2005 & China & $\begin{array}{l}\text { Abordou o tipo de implantação } \\
\text { que ocorreu do SGI (voluntária } \\
\text { ou compulsória), as razões para } \\
\text { a integração; os benefícios; e } \\
\text { necessidades para se integrar. }\end{array}$ \\
\hline $\begin{array}{l}\text { Zutshi, A.; Sohal, } \\
\text { A.S. }\end{array}$ & $\begin{array}{l}\text { Integrated management } \\
\text { system: The experiences of } \\
\text { three Australian organizations. }\end{array}$ & 2005 & Austrália & $\begin{array}{l}\text { Apresenta os desafios, } \\
\text { benefícios e fatores críticos de } \\
\text { sucesso relacionado à } \\
\text { integração. }\end{array}$ \\
\hline
\end{tabular}

Figura 17 - Resumo dos trabalhos sobre SGI (final) 


\section{APÊNDICE B - Carta enviada às empresas onde os especialistas que avaliaram o instrumento trabalham}

São Carlos, XX de XXXXXXXX de 2013

Prezado XXXXXXXX,

Venho por meio desta solicitar a permissão para realização de uma pesquisa na XXXX.

O objetivo da mesma é coletar percepções sobre o instrumento elaborado para avaliação da matudidade de Sistemas de Gestão Integrados (SGI). Essa pesquisa é vinculada à dissertação de mestrado que está sendo desenvolvida junto ao Departamento de Engenharia de Produção da USP/São Carlos, pelo Grupo de Pesquisa em Gestão da Qualidade e Mudança (GQM).

O foco maior está na avaliação do instrumento em si e não propriamente no diagnóstico do nível de maturidade da organização.

Pretende-se realizar uma visita à organização, onde será feito um breve detalhamento sobre o propósito da mesma e em seguida será avaliado o instumento em si, aproveitando para coletar as percepções do participante. Sua duração aproximada é de 2 horas.

É importante ressaltar que todas as informações serão tratadas de forma confidencial, portanto, o nome da organização não será divulgado em nenhum momento.

Me coloco à disposição para esclarecimentos.

Camila Fabrício Poltronieri Mestranda em Engenharia de Produção - USP/São Carlos

E-mail: camila_fabricio@sc.usp.br Fone: (14) 81428954 


\section{APÊNDICE C - Protocolo}

\section{Protocolo de Pesquisa}

\section{Informações gerais}

Esse trabalho visa verificar a adequação do Modelo de Maturidade para Sistemas de Gestão Integrados (SGI) proposto e para isso será coletada a opinião de pessoas que trabalham diretamente com SGI. As informações serão tratadas de forma sigilosa, onde o foco principal será a avaliação do instrumento em si e não propriamente a verificação do nível de maturidade, embora esse acabe sendo avaliado de forma indireta.

\section{$\underline{\text { Forma de avaliação }}$}

O contato será estabelecido com o responsável pela gestão do SGI, o qual irá realizar a avaliação do modelo e poderá solicitar o auxílio de mais pessoas caso considere interessante. O critério para seleção da empresa é que a mesma integre ao menos 2 sistemas de gestão. Pretende-se realizar 2 visitas, a primeira de cerca de aproximadamente meia hora para apresentação do grupo de pesquisa, da pesquisa em si e do que se pretende realizar; enquanto a segunda visita será com o intuito de aplicar/avaliar o modelo e deverá durar cerca de 2 horas, a qual poderá ser negociado conforme necessidade do entrevistado. Nessa segunda visita será solicitado que a empresa preencha o modelo de maturidade e ao mesmo tempo possa tirar suas dúvidas, impressões e sugestões do instrumento.

\section{$\underline{\text { Caracterização da organização }}$}

- perfil do(s) participante(s) - posição e formação

- área de atuação da organização

- normas que estão integradas; tempo de certificação de cada uma delas; quanto tempo trabalham de forma integrada as normas 


\section{$\underline{\text { Avaliação do Modelo de Maturidade }}$}

Questão de pesquisa:

Como avaliar o nível de maturidade de um Sistema de Gestão Integrado?

Quetões principais:

O modelo de maturidade está fácil de compreender? Houve alguma dificuldade no momento de repondê-lo?

Você considera que o modelo desenvolvido é um bom instrumento para avaliar a integração do SGI? Gostaria de fazer alguma sugestão para tornar o instrumento melhor? 